\title{
A standard tag set expounding traditional morphological features for Arabic language part-of-speech tagging ${ }^{1}$
}

\author{
Majdi Sawalha and Eric Atwell
}

\section{Abstract}

The SALMA Morphological Features Tag Set (SALMA, Sawalha Atwell Leeds Morphological Analysis tag set for Arabic) captures long-established traditional morphological features of grammar and Arabic, in a compact yet transparent notation. First, we introduce Part-of-Speech tagging and tag set standards for English and other European languages, and then survey Arabic Part-of-Speech taggers and corpora, and long-established Arabic traditions in analysis of morphology. A range of existing Arabic Part-of-Speech tag sets are illustrated and compared; and we review generic design criteria for corpus tag sets. For a morphologically-rich language like Arabic, the Part-of-Speech tag set should be defined in terms of morphological features characterizing word structure. We describe the SALMA Tag Set in detail, explaining and illustrating each feature and possible values. In our analysis, a tag consists of 22 characters; each position represents a feature and the letter at that location represents a value or attribute of the morphological feature; the dash '-' represents a feature not relevant to a given word. The first character shows the main Parts of Speech, from: noun, verb, particle, punctuation, and Other (residual); these last two are an extension to the traditional three classes to handle modern texts. 'Noun' in Arabic subsumes what are traditionally referred to in English as 'noun' and 'adjective'. The characters 2, 3, and 4 are used to represent subcategories; traditional Arabic grammar recognizes 34 subclasses of noun (letter 2), 3 subclasses of verb (letter 3), 21 subclasses of particle (letter 4). Others (residuals) and punctuation marks are represented in letters 5 and 6 respectively. The next letters represent traditional morphological features: gender (7), number (8), person (9), inflectional morphology (10) case or mood (11), case and mood marks (12), definiteness (13), voice (14), emphasized and non-emphasized (15), transitivity (16), rational (17), declension and conjugation (18). Finally there are four characters representing morphological information which is useful in Arabic text analysis, although not all linguists would 
count these as traditional features: unaugmented and augmented (19), number of root letters (20), verb root (21), types of nouns according to their final letters (22). The SALMA Tag Set is not tied to a specific tagging algorithm or theory, and other tag sets could be mapped onto this standard, to simplify and promote comparisons between and reuse of Arabic taggers and tagged corpora.

\section{Introduction: part-of-speech tagging and part-of-speech tag sets}

Part-of-speech taggers are used to enrich a corpus by adding a part-of-speech category label to each word, showing the broad grammatical class of the word, and morphological features such as tense, number, gender, etc. The list of all grammatical category labels is called the tag set. The design of the tag set is an important prerequisite to this annotation task. The task requires a tagging scheme, where each tag or label is practically defined by showing the words and contexts where each tag applies; and a tagger, a program responsible for assigning a tag to each word in the corpus by implementing tag set and tagging scheme in a tag-assignment algorithm (Atwell 2008).

Automatic taggers have been used from the early years of Corpus Linguistics. TAGGIT in 1971 achieved an accuracy of $77 \%$ tested on the Brown corpus. In the late 1970s, CLAWS1, a data-driven statistical tagger was built to carry out the annotation of the Lancaster/ Oslo-Bergen corpus (LOB), and had an accuracy rate of 96-97\%. Later tagger development included systems based on Hidden Markov Models (HMM); HMM taggers have been made for several languages. The Brill tagger (Brill 1995) is an example of data-driven symbolic tagger. The ENGCG and EngCG-2 are based on a framework known as Constraint Grammar (CG) (Voutilainen 2003).

Recently, many new systems based on a variety of Markov Model and Machine Learning (ML) techniques have appeared for many languages. Hybrid solutions have also been investigated (Voutilainen 2003). ACOPOST, ${ }^{2}$ A Collection Of POS Taggers, consists of four taggers of different frameworks: Maximum Entropy Tagger (MET), Trigram Tagger (T3), Error-driven Transformation-Based Tagger (TBT) and Example-based tagger (ET). The SNoW-based Part of Speech Tagger $^{3}$ and LBJ Part of Speech Tagger ${ }^{4}$ make use of the Sequential Model. NLTK, ${ }^{5}$ the Natural Language Toolkit, includes Python re-implementations of several POS taggers such as; Regexp Tagger, N-Gram Tagger, Brill Tagger and HMM Tagger; in addition NLTK includes tutorials and documentation on tagging. RelEx ${ }^{6}$ provides English-language part-of-speech tagging, entity tagging, as well as other types of tags (gender, date, money, etc.). Spejd ${ }^{7}-$ Shallow Parsing and Disambiguation Engine is a tool for simultaneous rule-based morphosyntactic disambiguation and partial parsing. VISL Constraint Grammar ${ }^{8}$ is an example of rule based disambiguation.

Enriching the source text samples of corpora with part-of-speech information for each word, as a first level of linguistic enrichment, results in more useful research resources. English corpora have been developed for a long time and for a variety of formats, types and genres. Several English corpora have been enriched with Part-of-Speech tagging, and a variety of different English corpus part-of-speech tag sets have been developed, including: the Brown corpus (BROWN), the 
Lancaster/ Oslo-Bergen corpus (LOB), the Spoken English Corpus (SEC), the Polytechnic of Wales corpus (PoW), the University of Pennsylvania corpus (UPenn), the London-Lund Corpus (LLC), the International Corpus of English (ICE), the British National Corpus (BNC), the Spoken Corpus Recordings In British English (SCRIBE), etc (Atwell 2008). The AMALGAM ${ }^{9}$ multi-tagged corpus amalgamates all these tagging schemes in a common collection of English texts: in the AMALGAM corpus, the different part-of-speech tag sets used in these English general-purpose corpora are applied to illustrate the range of rival English corpus tagging schemes, and the texts are also parsed according to a range of rival parsing schemes, so each sentence has more than one parse-tree, called 'a forest' (Atwell, Demetriou, Hughes, Schiffrin, Souter \& Wilcock 2000). Part-of-speech tag sets and taggers have also been developed for other European languages. The EAGLES, European Advisory Group on Language Engineering Standards project, drew up standards for tag sets, morphological classes and codes for (western) European languages, including EAGLES Recommendations for the morphosyntactic annotation of corpora (Leech \& Wilson 1999); a synopsis and comparison of morphosyntactic phenomena encoded in lexicons and corpora: a common proposal and applications to European languages (Monachini \& Calzolari 1996); and an EAGLES study of the relation between tag sets and taggers (Teufel, Schmid, Heid \& Schiller 1996).

The potential uses of a part-of-speech tagged corpus are key factors in deciding the range and number of part-of-speech tags. Many linguistic analyses use part-of-speech tagged corpora to analyse text and extract information, where part-of-speech tags play an essential role in classifying text and direct search to the actions, events, places, etc described in the text. The most obvious applications are in lexicography and natural language processing (NLP) computational linguistics. Further applications include using the tags in data compression (Teahan 1998); and as a possible guide in the search for extra-terrestrial intelligence (Elliott \& Atwell 2000). Other generic applications that make use of part-of-speech tag information are: searching and concordancing, grammatical error detection in Word Processing, training Neural Networks for grammatical analysis of text, or training statistical language processing models (Atwell 2008). Part-of-Speech tagging is a key technology in discovering suspicious events from text (Zolfagharifard 2009), and processing Arabic is a key task in discovering these suspicious events.

\section{I.I Arabic language part-of-speech taggers and corpora}

Arabic part-of-speech tagging development started more recently. A range of different techniques have been used to solve the problem of part-of-speech tagging of Arabic. The APT tagger uses a combination of both statistical Viterbi algorithm, and rulebased techniques (Khoja 2001). Brill's 'transformation-based' or 'rule-based' part-ofspeech tagger has been applied for Arabic (Freeman 2001). Harmain (2004) developed a web-based Arabic tagger. Diab, Hacioglu \& Jurafsky (2004) used Support Vector Machines (SVM), a supervised learning algorithm, to achieve an accuracy of $95 \%$. Habash \& Rambow (2005) developed another part-of-speech tagger that uses SVM and 
Viterbi decoding. HMM has been widely used in part-of-speech tagging for Arabic, with reported accuracy of $97 \%$ on LDC's Arabic Treebank of Modern Standard Arabic (Al-Shamsi \& Guessoum 2006) and 70\% when tested on CallHome Egyptian Colloquial Arabic (ECA) and the LDC Levantine Arabic (LDC) (Duh \& Kirchhoff 2005). Applications of Memory-based learning to morphological analysis and part-of-speech tagging of written Arabic have been explored (Marsi, Bosch \& Soudi 2005). Also, combinations of rule based and machine learning methods for tagging Arabic words (Tlili-Guiassa 2006). A multi-agent architecture was developed to address the problem of part-of-speech tagging of Arabic text with vowel marks (Zibri, Torjmen \& Ahmad 2006). A rule-based PoS tagging system, Arabic Morphosyntactic Tagger AMT (Alqrainy 2008), uses two different techniques: the pattern-based technique, which is based on using Pattern-Matching Algorithm (PMA), and lexical and contextual technique. The AMT tagger makes use of the last diacritic mark of Arabic words to reduce the tagging ambiguity. The accuracy of the AMT tagger reported was 91\%.

Nearly all these Arabic part-of-speech taggers were developed by NLP research groups for their own internal use, and are not freely downloadable by other researchers. The taggers use different tag sets, and accuracies are reported on different test corpora.

Arabic corpora ${ }^{10}$ started to appear in the late 1980s; the following list of Arabic corpora developed outlines their size, type, purpose of development and the materials of construction (Al-Sulaiti \& Atwell 2006):

- Buckwalter Arabic Corpus (1986-2003) consists of about 3 million words of public resources in the web to be used in lexicography.

- Leuven Corpus (1990-2004) developed at Catholic University Leuven, Belgium, consists of about 3 million words of written and spoken text from internet sources, radio and TV and primary school books, to be used in the development of Arabic-Dutch/Dutch-Arabic learner's dictionaries.

- Arabic Newswire Corpus (1994) developed at the University of Pennsylvania LDC, consists of 80 million words of written text collected from Agence France Presse (AFP), Xinhua News Agency, and Umma Press, to be used in education and the development of technology.

- CALLFRIEND Corpus (1995) developed at the University of Pennsylvania LDC consists of 60 telephone conversations of Egyptian native speakers, to be used in the development of language identification technology.

- Nijmegen Corpus (1996) developed at Nijmegen University consists of over 2 million written words collected from magazines and fiction, to be used in Arabic-Dutch/Dutch-Arabic dictionaries.

- CALLHOME Corpus (1997) developed at the University of Pennsylvania LDC, consists of 120 telephone conversations of Egyptian native speakers, to be used in telephony and speech recognition.

- CLARA (1997) developed at Charles University, Prague, consists of 50 million words collected from periodicals, books, internet sources from 1975-present, to be used for lexicography. 
- Egypt (1999) developed at Johns Hopkins University, a parallel corpus of the Qur'an in English and Arabic to be used in machine translation.

- Broadcast News Speech (2000) developed at University of Pennsylvania LDC, consists of more than 110 news broadcasts from the Voice of America radio station, to be used in speech recognition.

- DINAR Corpus (2000) developed at Nijmegen University and SOTETELIT, in co-ordination with Lyon2 University, consists of 10 million words, to be used in lexicography, general research, and NLP.

- An-Nahar Corpus (2001) developed by ELRA, consists of 140 million words of written text collected from An-Nahar newspaper (Lebanon), to be used in general text research.

- Al-Hayat Corpus (2002) developed by ELRA consists of 18.6 million of written text collected from Al-Hayat newspaper (Lebanon), to be used for language engineering and information retrieval applications.

- Arabic Gigaword (2002) developed at the University of Pennsylvania LDC, consists of around 400 million words collected from Agence France Presse (AFP), Al-Hayat news agency, An-Nahar news agency and Xinhua news agency, to be used in natural language processing, information retrieval and language modelling.

- E-A Parallel Corpus (2003) developed at the University of Kuwait, consists of 3 million words of written text collected from publications from Kuwait National Council, to be used in teaching, translation and lexicography.

- General Scientific Arabic Corpus (2004) developed at UMIST, UK, consists of 1.6 words of written text, to be used in investigating Arabic compounds.

- Classical Arabic Corpus (CAC) (2004) developed at UMIST, UK, consists of 5 million words of written text, to be used in lexical analysis.

- Multilingual Corpus (2004) developed at UMIST, UK, consists of 11.5 million words of written text including 2.5 million words in Arabic, collected from ITspecialized websites to be used in translation studies.

- SOTETEL Corpus developed at SOTETEL-IT, Tunisia, consists of 8 million words of written text collected from literature, academic and journalistic materials, to be used in lexicography.

- Corpus of Contemporary Arabic (CCA) (2004) developed at the University of Leeds, consists of 1 million words of written and spoken data, collected from websites and online magazines, to be used in language teaching and language technology.

- DARPA Babylon Levantine Arabic Speech and Transcripts (2005) developed at the University of Pennsylvania LDC, consists of about 2,000 telephone calls collected from Fisher style telephone speech collection, to be used in machine translation, speech recognition and spoken dialogue systems.

- The Penn Arabic Treebank (2001) Part 1 consists of 166,000 words of written Modern Standard Arabic newswire from the Agence France Presse 
corpus; and Part 2 consists of 144,000 words from Al-Hayat distributed by Ummah Arabic News Text, to be used in computational linguistics. New features of annotation in the UMAAH (UMmah Arabic Al-Hayat) corpus include complete vocalization (including case endings), lemma IDs, and more specific part-of-speech tags for verbs and particles. The Arabic Treebank corpora are annotated for morphological information, part-of-speech, English gloss (all in the "part-of-speech" phase of annotation), and for syntactic structure (Maamouri \& Bies, 2004).

- The Quranic Arabic Corpus (QAC) (2009) contains the classical Arabic source text of the Quran, the holy book of Islam. The text consists of nearly 80,000 words, divided into numbered chapters and verses. The text is being enriched with morphological analysis, Part-of-Speech tagging, dependency parsing, coreference resolution, and other linguistic markup, via a collaborative web-based project. The annotated corpus is online, used by Quranic scholars, linguists, and the general public with an interest in Islam.

Nearly all these corpora have been collected by Arabic corpus linguistics research groups for their own purposes, and are not freely downloadable. The Corpus of Contemporary Arabic (CCA) (Al-Sulaiti \& Atwell 2004; Al-Sulaiti \& Atwell 2005; Al-Sulaiti \& Atwell 2006), and the Quranic Arabic Corpus (QAC) (Dukes, Atwell \& Sharaf 2010), both developed at the University of Leeds, are the only freely available Arabic corpora on the web which have been widely reused for linguistic research. The CCA is not annotated with part-of-speech tags, but the QAC is annotated with morphological segmentation and morpho-syntactic tags. In computational linguistics research, the most widely used annotated corpus of Arabic is the Penn Arabic Treebank (Maamouri \& Bies 2004) developed at the University of Pennsylvania and distributed (at cost) by the LDC Linguistic Data Consortium.

\section{I.2 Traditional Arabic part-of-speech classification}

Arabic, unlike English and modern European languages, has a long tradition of scholarly research into its grammatical description, spanning over a millennium. Most

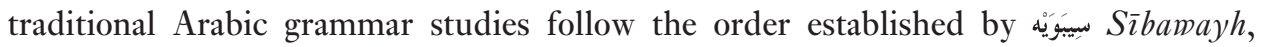
about fourteen hundred years ago. It starts with syntax ن nahm, followed by morphology تصريف taṣrîf, and phonology علم الأصوات al-'aṣmāt. The grammarian's main preoccupation was the explanation of the case ending of the words in the sentence, called إعراب 'i'rāb. The term originally meant the correct use of Arabic according to the language of the Bedouins but came to mean 'declension'. Classical Arabic linguists classify words into three main parts of speech: Noun, name of a person, place, or object which does not have any tense; Verb, a word which indicates an action and has tense; and Particle, a word which cannot be understood without being connected to a noun or a verb or both. However, there are also morphological criteria for this classification: a verb can be defined as a word derived from a specified morphological pattern, and has morphological features such as person and mood; while 
a noun can be definite or indefinite and has number and gender features. Derived nouns, which are derived from verbs, may have the same pattern as verbs. Particles are considered the most idiosyncratic words in Arabic, as these particles might span several grammatical categories. For example the particle $m a$ ' can indicate a conjunction

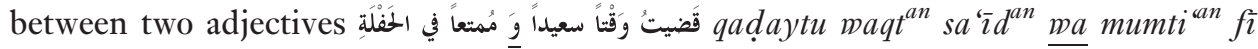
al-haflati 'I spent an interesting and happy time at the party', while, in another case, the same particle $m a$ وَشَيتُ وَ النَّرَ functions as locative preposition in the sentence mašaytu ma an-nahra 'I walked along the river' (Al-Ghalayyni 2005).

Arabic is a highly inflectional language, and the traditional classification into nouns, verbs and particles does not say much about word structure. Arabic has many morphological and grammatical features, including sub-categories, person, number, gender, case, mood, etc. (Atwell 2008). A fine-grained tag set is appropriate for morphology research. The additional information may also help to disambiguate the base grammatical class (Schmid \& Laws 2008). We aim to develop a part-of-speech tagger for annotating general-purpose Arabic corpus resources, in a wide range of text formats, domains and genres, including both vowelized and non-vowelized text; enriching the text with linguistic analysis will maximize the potential for corpus re-use in a wide range of applications. We foresee an advantage in enriching the text with part-of-speech tags showing very fine-grained grammatical distinctions, which reflect expert interest in syntax and morphology, rather than specific needs of end-users, because end-user applications are not known in advance.

Very fine-grain distinctions may cause problems for automatic tagging if some words can change grammatical tag depending on function and context (Atwell 2008); on the other hand, fine-grained distinctions may actually help to disambiguate other words in the local context. Practical experiments using a fine-grain morphological tag set were reported by (Schmid \& Laws 2008). Their experiments were carried out using German and Czech as examples of highly inflectional languages. Their HMM part-of-speech tagger makes good use of the fine-grain tag set; it splits the part-of-speech into attribute vectors and estimates the conditional probabilities of the attribute with decision trees. This method achieved a higher tagging accuracy than two state-of-theart general-purpose part-of-speech taggers (TnT and SVMTool). We believe that this kind of approach may yield better results for an Arabic part-of-speech tag set including fine-grained morphological features.

\section{I.3 Existing Arabic part-of-speech tag sets}

This section covers the most important Arabic tag sets and tag set design methodologies. These tag sets are; (1) Khoja's Arabic tag set, (2) Penn Arabic Treebank tag set, (3) ARBTAGS, (4) The Quranic Arabic Corpus morphological tag set, (5) The MorphoChallenge 2009 Qur'an Gold Standard tag set and (6) CATiB part-of-speech tag set. The section describes each tag set and their characteristics, and a comparison table illustrates the differences between the different Arabic tag sets. The tag sets range from a small set of short tags analogous to BNC or LOB tag sets for English on one hand, to On the other hand, longer more detailed morphological tag 


\begin{tabular}{|c|c|c|c|}
\hline Word & & & Khoja's part-of-speech tag \\
\hline تنفيذاً & $\operatorname{tanfi} \underline{d}^{a n}$ & Implementation & NCSgMI \\
\hline ل لتوجيهات & li-tawğ̄̄hāt & directives & PPr'NCSgMI \\
\hline 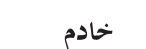 & hāadim & Custodian & NCSgMI \\
\hline الحرمين & al-ḥaramayn & Two Mosques & NCDuMD \\
\hline 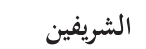 & $a \check{s}$-šarīfayn & Holy & NCDuMD \\
\hline
\end{tabular}

Figure 1. Example of tagged sentence using Khoja's tag set.

sets (e.g. Penn Arabic Treebank (FULL) tag set) which are analogous to the ICE tag set for English.

\section{I.3.I Khoja's Arabic tag set}

During early research on developing a part-of-speech tagger for Arabic text, Khoja (Khoja, Garside \& Knowles 2001; Khoja 2003) developed a tag set for Arabic which is based on traditional Arabic grammar categories rather than on modern European EAGLES standards. The reasons for not following EAGLES morphosyntactic guidelines were: Arabic belongs to the Semitic language family while EAGLES guidelines were designed for European languages; and following EAGLES guidelines would not capture some Arabic morphosyntactic information such as imperative or jussive mood, dual number and inheritance. Inheritance is an important aspect of Arabic, where all subclasses of words inherit properties from the classes from which they are derived. Khoja's tag set contains 177 tags; 103 types of noun, 57 verbs, 9 particles, 7 residuals and 1 punctuation. Khoja's tag set includes the morphological features of gender, number, person, case, definiteness and mood. Figure 1 shows an example of a

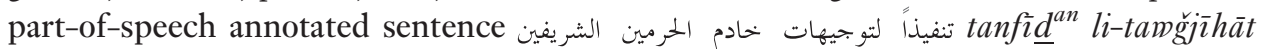
hädim al-ḩaramayn aš-šarîfayn 'Implementation of the directives of the Custodian of the Two Holy Mosques', taken from the training corpus of the APT tagger (Khoja 2003).

\subsubsection{Penn Arabic Treebank (PATB) part-of-speech tag set}

The most widely used tag set for Arabic is the Penn Arabic Treebank tag set used to annotate the Penn Arabic Treebank (PATB) with part-of-speech tags. Tim Buckwalter's morphological analyser was used to compute a set of candidate solutions or analyses for each word, and then Arabic linguists selected the solution which best fitted the context. The Penn Arabic Treebank model postulates a FULL tag set which compromises over 2,000 tag types (Diab 2007). This includes combinations of 114 basic tags listed in the Linguistic Data Consortium (LDC) Arabic part-of-speech/morphological tagging documentation. ${ }^{11}$ Figure 2 shows these basic tags. 


\begin{tabular}{|c|c|c|}
\hline ABBREV & IVSUFF_SUBJ : 2FS_MOOD :SJ & POSS_PRON_3MP \\
\hline ADJ & IVSUFF_SUBJ : D_MOOD: I & POSS_PRON_3MS \\
\hline ADV & IVSUFF_SUBJ :D_MOOD : SJ & PREP \\
\hline CONJ & IVSUFF_SUBJ :FP & PRON_1P \\
\hline DEM_PRON_F & IVSUFF_SUBJ :MP_MOOD: I & PRON_1S \\
\hline DEM_PRON_FD & IVSUFF_SUBJ :MP_MOOD:SJ & PRON_2FS \\
\hline DEM_PRON_FS & NEG_PART & PRON_2MP \\
\hline DEM_PRON_MD & NO_FUNC & PRON_2MS \\
\hline DEM_PRON_MP & NON_ALPHABETIC & PRON_3D \\
\hline DEM_PRON_MS & NON_ARABIC & PRON_3FP \\
\hline $\mathrm{DET}^{-}-$ & NOUN & PRON_3FS \\
\hline EMPHATIC_PARTICLE & NOUN_PROP & PRON_3MP \\
\hline EXCEPT_PART & NSUFF_FEM_DU_ACCGEN & PRON_3MS \\
\hline FUNC_WORD & NSUFF_FEM_DU_ACCGEN_POSS & PUNC \\
\hline FUT & NSUFF_FEM_DU_NOM & PVSUFF_DO : $1 \mathrm{P}$ \\
\hline INTERJ & NSUFF_FEM_DU_NOM_POSS & PVSUFF_DO : $1 \mathrm{~S}$ \\
\hline INTERROG_PART & NSUFF_FEM_PL & PVSUFF_DO : 3D \\
\hline IV1P & NSUFF_FEM_SG & PVSUFF_DO:3FS \\
\hline IV1S & NSUFF_MASC_DU_ACCGEN & PVSUFF_DO:3MP \\
\hline IV2D & NSUFF_MASC_DU_ACCGEN_POSS & PVSUFF_DO : 3MS \\
\hline IV2FS & NSUFF_MASC_DU_NOM & PVSUFF_SUBJ : $1 \mathrm{P}$ \\
\hline IV2MP & NSUFF_MASC_DU_NOM_POSS & PVSUFF_SUBJ : $1 \mathrm{~S}$ \\
\hline IV2MS & NSUFF_MASC_PL_ACCGEN & PVSUFF_SUBJ $: 2 \mathrm{FS}$ \\
\hline IV3FD & NSUFF_MASC_PL_ACCGEN_POSS & PVSUFF_SUBJ : $2 \mathrm{MP}$ \\
\hline IV3FP & NSUFF_MASC_PL_NOM & PVSUFF_SUBJ $: 3 \mathrm{FD}$ \\
\hline IV3FS & NSUFF_MASC_PL_NOM_POSS & PVSUFF_SUBJ $: 3 \mathrm{FP}$ \\
\hline IV3MD & NSUFF_MASC_SG_ACC_INDEF & PVSUFF_SUBJ $: 3 \mathrm{FS}$ \\
\hline IV3MP & NUM $--1--$ & PVSUFF_SUBJ : $3 \mathrm{MD}$ \\
\hline IV3MS & NUMERIC_COMMA & PVSUFF_SUBJ : $3 \mathrm{MP}$ \\
\hline IVSUFF_DO $: 1 \mathrm{P}$ & PART & PVSUFF_SUBJ : $3 \mathrm{MS}$ \\
\hline IVSUFF_DO: $1 \mathrm{~S}$ & POSS_PRON_1P & REL_PRON \\
\hline IVSUFF_DO:2MP & POSS_PRON_1S & REL_ADV \\
\hline IVSUFF_DO:2MS & POSS_PRON_2FS & RESULT_CLAUSE_PART \\
\hline IVSUFF_DO:3D & POSS_PRON_2MP & ICLE \\
\hline IVSUFF_DO:3FS & POSS_PRON_2MS & SUBJUNC \\
\hline IVSUFF_DO:3MP & POSS_PRON_3D & VERB_IMPERFECT \\
\hline \multirow[t]{2}{*}{ IVSUFF_DO:3MS } & POSS_PRON_3FP & VERB_PERFECT \\
\hline & POSS_PRON_3FS & VERB_PASSIVE \\
\hline
\end{tabular}

Figure 2. The Penn Arabic Treebank Tag Set; basic tags, which can be combined.

The FULL tag set exhibits a wide range of morphological features: case, gender, number, definiteness, mood, person, voice, tense, aspect, etc. The LDC also introduced the reduced tag set (RTS) of 25 tags which is designed to maximize the performance of Arabic syntactic parsing. The RTS follows the tag set designed for the English Wall Street Journal. The morphological features marked by the RTS tag set are case, mood, gender, person and definiteness (Diab 2007).

Figures 3-6 show examples of two sentences tagged by the FULL tag set. The first sentence is a newspaper text taken from the Arabic Treebank: tamma 'ídād al-matāàiqa al-

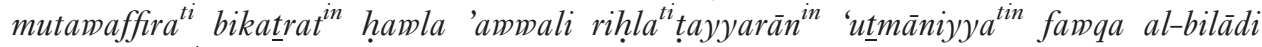
al-'arabiyya' 'Many available documents relate to the first Ottoman's flight over the Arab countries'. The second sentence is taken from the Qur'an (chapter 29):

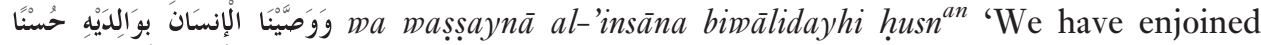




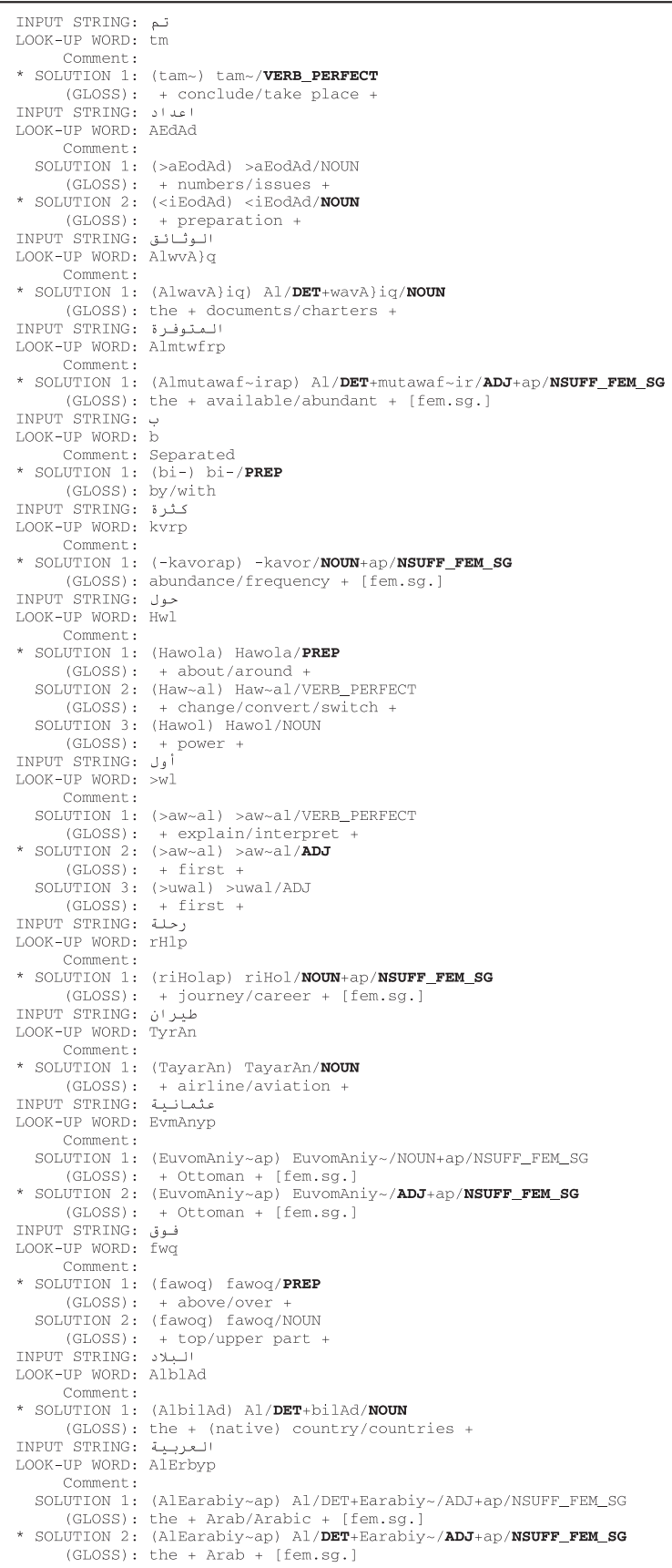

Figure 3. Buckwalter's morphological analysis of a sentence from the Arabic Treebank. 


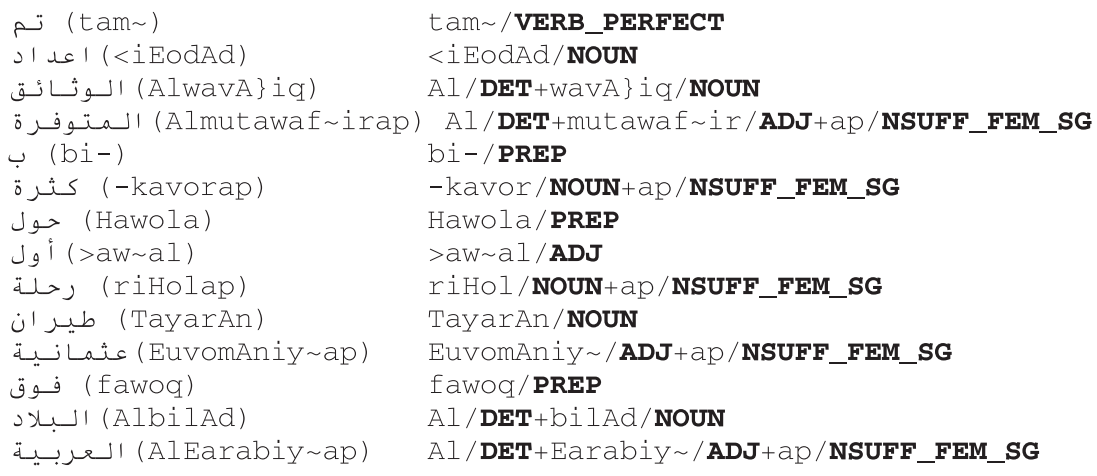

Figure 4. Disambiguated sentence from the Arabic Treebank using the FULL tag set.

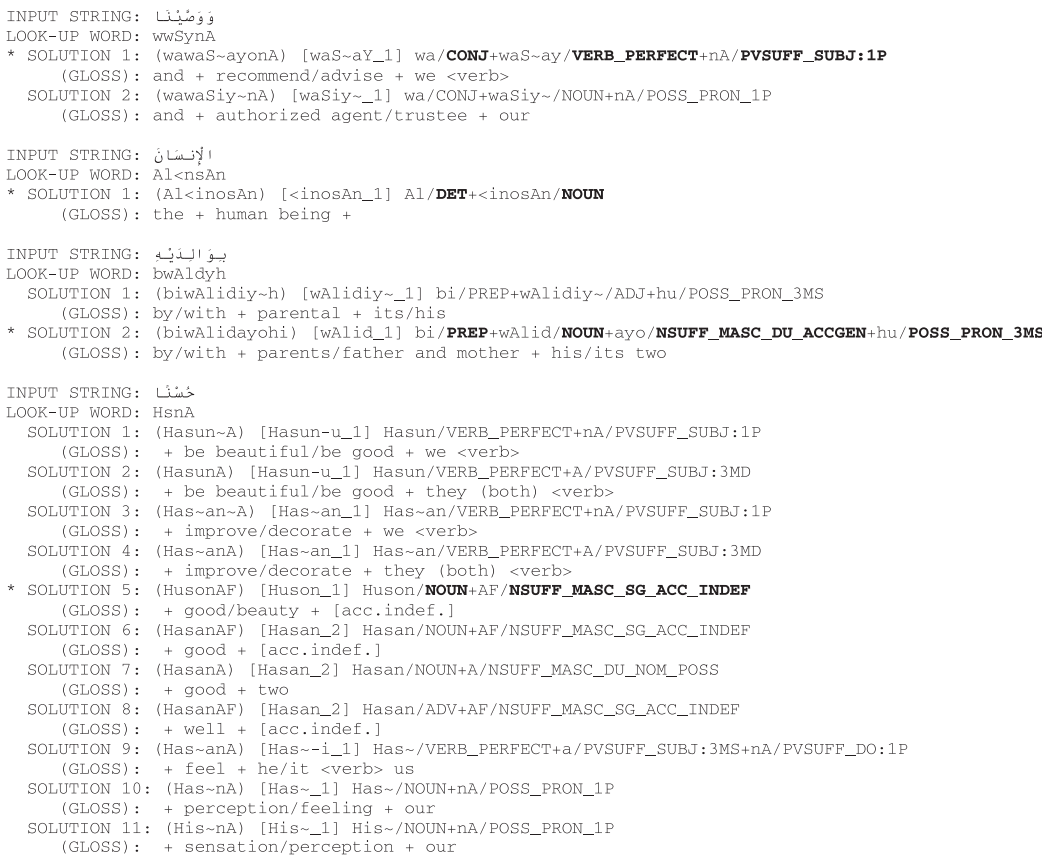

Figure 5. Buckwalter's morphological analysis of a sentence from the Quran.

on man kindness to parents'. Figures 3 and 5 show the full outputs of Buckwalter's morphological analyser including several possible solutions for some words. Figures 4 and 6 show the correct disambiguated solution for each word in context. 


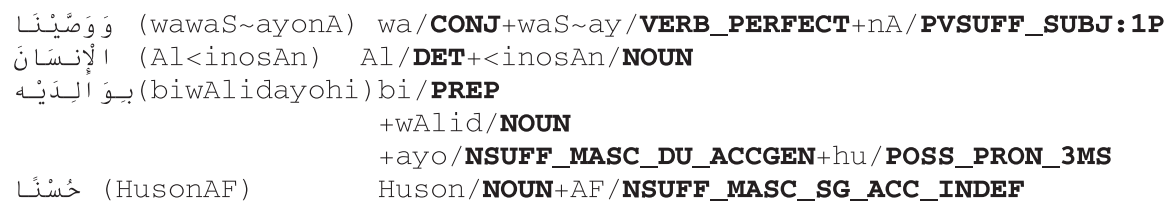

Figure 6. Disambiguated sentence from the Quran using the FULL tag set.

\begin{tabular}{|c|c|c|c|c|c|}
\hline & & & FULL & RTS & ERTS \\
\hline حصيلة & HSylp & 'result' & NOUN+NSUFF_FEM_SG+CASE_IND_NOM & NN & NNF \\
\hline فهائية & nhA\}yp & 'final' & ADJ+NSUFF_FEM_SG+CASE_IND_NOM & $\mathbf{J J}$ & JJF \\
\hline حادث & HAdv & 'accident' & NOUN+CASE_DEF_ACC & $\mathbf{N N}$ & NNM \\
\hline النار & $\mathrm{Aln} \mathrm{Ar}$ & 'the-fire' & DET+NOUN+CASE_DEF_GEN & $\mathbf{N N}$ & DNNM \\
\hline البحماعي & AlimAEy & 'group' & DET+ADJ+CASE_DEF_GEN & $\mathbf{J J}$ & DJJM \\
\hline شخصين & \$xSyn & 'two-persons' & NOUN+NSUFF_MASC_DU_GEN & $\mathbf{N N}$ & NNMDu \\
\hline
\end{tabular}

Figure 7. A sample of tagged sentence using the FULL, RTS and ERTS tag sets.

Diab (2007) compared the FULL and RTS tag sets introduced by the LDC to PoStag the Arabic Treebank. The study is about designing the optimal part-of-speech tag set for Arabic. By analyzing the Arabic Treebank data, the RTS tag set is extended from 25 tags to 75 tags. Only morphological features, which are explicitly marked on the words, are added to the RTS. The new tag set is called the ERTS (extended reduced tag set). The ERST has only the explicit or marked morphological features of gender, number and definiteness on nominals while maintaining the existing features from RTS. Figure 7 illustrates some differences between the three tag sets: FULL, RTS and ERTS from (Diab 2007).

\section{I.3.3 ARBTAGS tag set}

Alqrainy (2008) developed a new part-of-speech tag set called ARBTAGS to be used in the development of a part-of-speech tagger. The tag set design followed the criteria proposed by Atwell (2008). Like Khoja, Alqrainy built on traditional Arabic grammar books to design the tag set. Six morphological features of Arabic words were included: gender, number, case, mood, person and state. ARBTAGS contains 161 detailed tags and 28 general tags to cover the main part-of-speech classes and sub-classes. The 161 detailed tags are divided into 101 nouns, 50 verbs, 9 particles and 1 punctuation mark. Figure 8 shows the 28 general tags of the ARBTAGS tag set.

\section{I.3.4 MorphoChallenge 2009 Qur'an gold standard part-of-speech tag set}

MorphoChallenge $2009^{12}$ Qur'an gold standard is developed using the data of Morphological Tagging of the Qur'an database (Talmon \& Wintner 2003; Dror, 


\begin{tabular}{|llll|}
\hline Tag & Description & Tag & Description \\
\cline { 2 - 2 } & Perfect verb & $\mathrm{NuCd}$ & Conditional noun \\
$\mathrm{VePi}$ & Imperfect verb & $\mathrm{NuDe}$ & Demonstrative noun \\
$\mathrm{VePm}$ & Imperative verb & $\mathrm{NuIn}$ & Interrogrative noun \\
$\mathrm{NuPo}$ & Proper noun & $\mathrm{NuAd}$ & Adverb \\
$\mathrm{NuCn}$ & Common noun & $\mathrm{NuNn}$ & Numeral noun \\
$\mathrm{NuAj}$ & Adjective noun & $\mathrm{Fw}$ & Foreign noun \\
$\mathrm{NuIf}$ & Infinitive noun & $\mathrm{Pun}$ & Punctuation mark \\
$\mathrm{NuRe}$ & Relative noun & $\mathrm{PrPp}$ & Preposition \\
$\mathrm{NuDm}$ & Diminutive noun & $\mathrm{PrVo}$ & Vocative Particle \\
$\mathrm{NuIs}$ & Instrument noun & $\mathrm{PrCo}$ & Conjunction Particle \\
$\mathrm{NuPn}$ & Noun of Place & $\mathrm{PrEx}$ & Exception Particle \\
$\mathrm{NuTn}$ & Noun of Time & $\mathrm{PrAn}$ & Annulment Particle \\
$\mathrm{NuPs}$ & Pronoun & $\mathrm{PrSb}$ & Subjunctive Particle \\
$\mathrm{NuCv}$ & Conjunctive noun & $\mathrm{PrJs}$ & Jussive Particle \\
\hline
\end{tabular}

Figure 8. The 28 general tags of the ARBTAGS tag set.

\begin{tabular}{|c|c|c|c|}
\hline وَوَصَّنَنَا & وصي & يُفَعِّلُ & 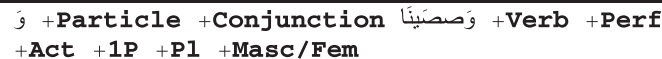 \\
\hline الْإنسَنانَ & 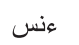 & فِعَلان & عِ \\
\hline بِوَ الَِيَنْهِ & ولد & فَاعِل & $\begin{array}{l}\text { + وَالِ +Noun +Triptotic +Dual +Masc } \\
\text { +Obliquus +Pron +Dependent +3P +Sg +Masc }\end{array}$ \\
\hline حُسنًْا & 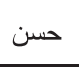 & فُعل & $\begin{array}{l}\text { حُسن +Noun +Triptotic +Sg +Masc +Acc } \\
\text { +Tanwiin }\end{array}$ \\
\hline wawas ayonaA & wSy & yufaE ilu & $\begin{array}{l}\text { wa +Particle +Conjunction waSSaynaA +Verb } \\
+ \text { Perf +Act }+1 \mathbf{P}+\mathbf{P 1}+\text { Masc/Fem }\end{array}$ \\
\hline Alo<insaAna & 'ns & fiElaAn & $\begin{array}{l}\text { 'insaAn +Noun +Triptotic +Sg +Masc +Acc } \\
\text { +Def }\end{array}$ \\
\hline biwaAlidayohi & wld & faAEil & $\begin{array}{l}\text { b +Prep waAlid + Noun + Triptotic + Dual } \\
\text { +Masc +Obliquus + Pron +Dependent }+3 \mathbf{P}+\mathbf{S g} \\
\text { +Masc }\end{array}$ \\
\hline HusonfA & Hsn & fuEl & $\begin{array}{l}\text { Husn +Noun +Triptotic }+\mathbf{S g}+\text { Masc }+ \text { AcC } \\
+ \text { Tanwiin }\end{array}$ \\
\hline
\end{tabular}

Figure 9. A sample of tagged sentence taken from the MorphoChallenge 2009 Qur'an Gold Standard, the first part uses Arabic script and the second one uses romanized letters using Tim Buckwalter's; transliteration scheme.

Shaharabani, Talmon \& Wintner 2004). It was developed to be used to evaluate morphological analyzers in the Morphochallenge 2009 competition, which aims to develop an unsupervised morphological analyzer to be used for different languages including Arabic. It contains the full morphological analysis for each word, according to the Tagged database of the Qur'an but reformatted to match other Morphochallenge test sets in other languages. The word's morphological analysis is shown after each word where the morphological features are separated by space and "+" sign. These features include the part-of-speech of the word, number, gender, 
person, case, definiteness, voice and others. Figure 9 shows a sample of the Qur'an gold standard.

\subsubsection{The Quranic Arabic Corpus part-of-speech tag set}

The Quranic Arabic Corpus is a newly available resource enriched with multiple layers of annotation including morphological segmentation and part-of-speech tagging. The motivation behind this work is to produce a resource that enables further analysis of the Qur'an; a genre difficult to compare with other forms of Arabic, since the vocabulary and the spelling differ from modern standard Arabic (Dukes \& Habash 2010).

Buckwalter's Arabic Morphological Analyzer (BAMA) was used to generate the initial tagging. The analyzer was adapted to work with the Quranic Arabic text. After that, the annotated corpus was put online to allow for collaborative annotation (Dukes \& Habash 2010; Dukes, Atwell \& Habash 2011).

A mapping was required to convert from the BAMA tag set to the Quranic Arabic Corpus tag set. Manual disambiguation was required for a few cases, where one-to-one mapping was not applicable such as particles. In order to adapt BAMA to process the Quranic Arabic Corpus text three modifications were made. First, spelling in the Qur'an differs from MSA. The differences involve orthographic variations of $h a m z a^{h}$, 'alif and the long vowel $\bar{a}$. Second, the multiple diacritized analyses produced by BAMA for the processed words were ranked in terms of their edit-distance from the Qur'anic diacritization, with closer match ranked higher. Finally, filtering was done by choosing the highest rank analysis's part of speech as a solution (Dukes \& Habash 2010).

The Quranic Arabic Corpus tag set adapts historical traditional Arabic grammar, which leads to morphological annotation that uses terminology familiar to many readers of the Qur'an. This terminology enables people with Qur'anic syntax experience to participate in the online annotation to be verified against existing authenticated books on Quranic Grammar (Dukes \& Habash 2010). Figure 10 shows a sample of the morphological and part-of-speech tags of the Quranic Arabic Corpus.

\section{I.3.6 Columbia Arabic Treebank CATiB part-of-speech tag set}

Another tag set was designed for the part-of-speech and syntactic annotation in the Columbia Arabic Treebank (CATiB). A part-of-speech tag set consisting of only six tags is used for the part-of-speech annotation of CATiB. The main reason for using such a small tag set is a tradeoff between linguistic richness and Treebank size. The researchers' assumption for morpho-syntactically rich languages such as Arabic, is that the cost of fine-grain annotation is a slower annotation process, a smaller Treebank and less data to train tools. CATiB is inspired by two ideas. First, it avoids annotation of redundant linguistic information. Second, it uses linguistic representation and terminology from traditional Arabic syntactic studies 


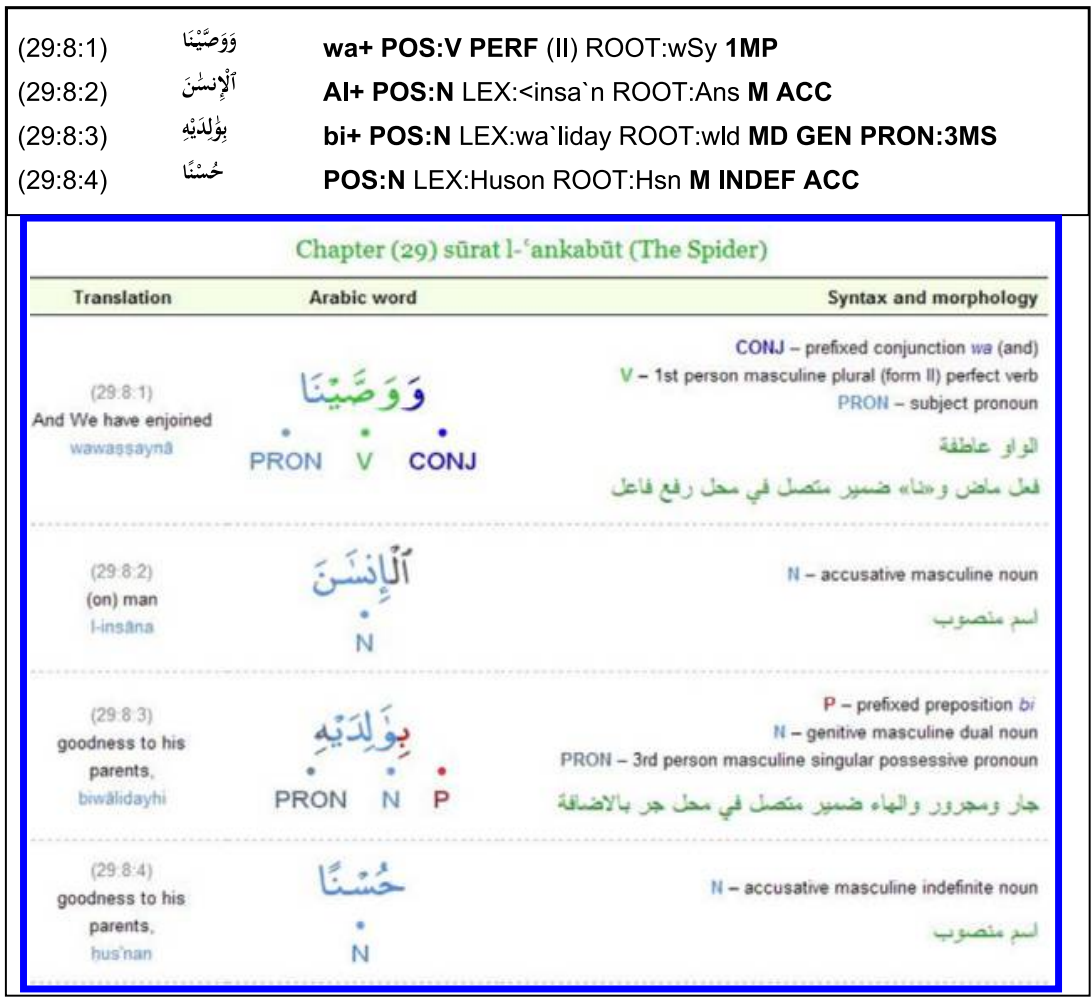

Figure 10. A sample of a tagged sentence taken from the Quranic Arabic Corpus.

(Habash, Faraj \& Roth 2009). The tag set is much smaller than the FULL tag set used by the Penn Arabic Treebank:

[...] CATiB uses the same tokenization scheme used by PATB and PADT. However, unlike these resources, the CATiB POS tag set is much smaller. Whereas PATB uses 2,200 tags specifying every aspect of Arabic word morphology such as definiteness, gender, number, person, mood, voice and case; CATiB uses six POS tags: NOM (nominals such as nouns, pronouns, adjectives and adverbs), PROP (proper noun), VRB (verb), VRB-PASS (passive verb), PRT (particles such as prepositions or conjunctions) and PNX (punctuation). (Habash \& Roth 2009: 2)

Figure 11 shows an example of the sentence, خمسون ألف سائح زاروا لبنان وسوريا في أيلول الماضي

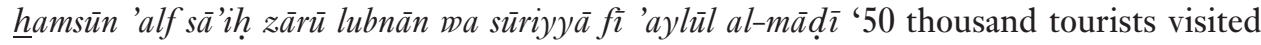
Lebanon and Syria last September', tagged using part-of-speech tags used in the CATiB (Habash \& Roth 2009). 


\begin{tabular}{|c|c|c|c|c|}
\hline \multicolumn{3}{|l|}{ Word } & CATiB part-of-speech tag & CATiB annotation \\
\hline خمسون & hamsūn & Fifty & NOM & \\
\hline ألف & 'alf & Thousand & NOM & 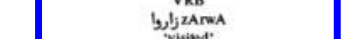 \\
\hline 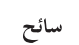 & $s \bar{a}$ 'ịh & Tourist & NOM & \\
\hline زاروا & $z \bar{a} r \bar{u}$ & Visited & VRB & Mod \\
\hline 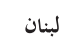 & lubnān & Lebanon & PROP & 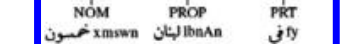 \\
\hline 9 & $w a$ & And & PRT & $\begin{array}{cc}\text { 'Afy' } & \text { 'Lebanon' } \\
1 & \text { Iod }\end{array}$ \\
\hline 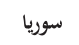 & sūriyyā & Syria & PROP & NOM \\
\hline في & $f i$ & In & PRT & 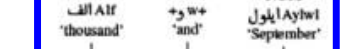 \\
\hline أيلول أ & 'aylül & September & NOM & MOD \\
\hline الماضي & $a l-m \bar{a} d \underline{l}$ & Past & NOM & 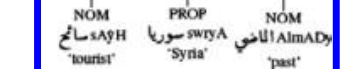 \\
\hline
\end{tabular}

Figure 11. Example of part-of-speech tagged sentence using CATiB tag set.

\subsubsection{Comparison of Arabic part-of-speech tag sets}

Table 1 shows a comparison of the seven Arabic tag sets studied in this section. The comparison summarizes the characteristics of each tag set and helps to show the differences between them clearly. The drawbacks of the existing tag sets for Arabic were found to be:

- Existing Arabic tag sets vary in size from 6 tags to 2,000 or more tags.

- Some of these tag sets follow standards for tag set design for English such as the PATB tag sets, and these may not always be appropriate for Arabic.

- The tag sets share common morphological features such as gender, number, person, case, mood and definiteness, but the attributes of the morphological feature categories are not standardized.

- These tag sets lack standardization in defining a suitable scheme for tokenizing Arabic words into their morphemes and they mix morpheme tagging with whole word tagging.

- They also lack suitable documentation that illustrates the decision made for each design dimension of the tag set.

- The tags assigned to words in a corpus are not consistent in either presentation of the tag itself or the morphological features which are encoded within the tag.

Moreover, the most widely used and important morphosyntactic annotation standards and guidelines, namely EAGLES (see section 2), are designed for Indo-European languages. These guidelines are not entirely suitable for Arabic. These drawbacks of existing tag sets are the motivation behind the SALMA (Sawalha Atwell Leeds Morphological Analysis) Tag Set for Arabic. 
Table 1. Comparison of Arabic part-of-speech tag sets.

\begin{tabular}{|c|c|}
\hline \multicolumn{2}{|l|}{ Khoja's tag set } \\
\hline Purpose of design & Compiling a tag set as a standard tag set. \\
\hline $\begin{array}{l}\text { Main } \\
\text { characteristics }\end{array}$ & $\begin{array}{l}\text { Based on traditional Arabic grammar rather than being based on an } \\
\text { Indo-European one. Only the main classes and subclasses have been } \\
\text { chosen. }\end{array}$ \\
\hline Tag set size & $\begin{array}{l}177 \text { tags (103 types of noun, } 57 \text { verbs, } 9 \text { particles, } 7 \text { residuals, } 1 \\
\text { punctuation mark) }\end{array}$ \\
\hline $\begin{array}{l}\text { Morphological } \\
\text { features }\end{array}$ & Gender, Number, Case, Definiteness, Person, Mood \\
\hline Applications & $\begin{array}{l}\text { Used in the design of the APT tagger, and in the annotation of the } \\
\text { training data of the APT tagger. }\end{array}$ \\
\hline \multicolumn{2}{|c|}{ Penn Arabic Treebank (PATB) Part-of-Speech Tag Set (FULL) } \\
\hline Purpose of design & Annotating the Arabic Treebank with part-of-speech tags. \\
\hline $\begin{array}{l}\text { Main } \\
\text { characteristics }\end{array}$ & Aims to cover detailed grammar features. \\
\hline Tag set size & $\begin{array}{l}\text { The FULL tag set comprises over } 2,000 \text { tag types. This includes } \\
\text { combinations of } 114 \text { basic tags. }\end{array}$ \\
\hline $\begin{array}{l}\text { Morphological } \\
\text { features }\end{array}$ & $\begin{array}{l}\text { Case, Gender, Number, Definiteness, Mood, Person, Voice, Tense, } \\
\text { Aspect }\end{array}$ \\
\hline Applications & $\begin{array}{l}\text { Used in Tim Buckwalter's morphological analyser to annotate the Penn } \\
\text { Arabic Treebank with part-of-speech tags. }\end{array}$ \\
\hline \multicolumn{2}{|c|}{ Penn Arabic Treebank (PATB) Reduced Part-of-Speech Tag Set (RTS) } \\
\hline Purpose of design & Maximizing the performance of Arabic syntactic parsing. \\
\hline $\begin{array}{l}\text { Main } \\
\text { characteristics }\end{array}$ & Follows the tag set designed for the English Wall Street Journal. \\
\hline Tag set size & 25 tags \\
\hline $\begin{array}{l}\text { Morphological } \\
\text { features }\end{array}$ & Case, Mood, Gender, Person, Definiteness \\
\hline Applications & Used in the syntactic annotation of the Penn Arabic Treebank \\
\hline \multicolumn{2}{|c|}{ Penn Arabic Treebank (PATB) Extended Reduced Part-of-Speech Tag Set (ERTS) } \\
\hline Purpose of design & To be used for higher order processing of the language \\
\hline $\begin{array}{l}\text { Main } \\
\text { characteristics }\end{array}$ & $\begin{array}{l}\text { Is an extension of the RTS tag set, which has only the explicit or marked } \\
\text { morphological features of gender, number and definiteness on nominals. }\end{array}$ \\
\hline Tag set size & 75 tags \\
\hline $\begin{array}{l}\text { Morphological } \\
\text { features }\end{array}$ & Gender, Number, Definiteness on nominals \\
\hline Applications & To be used for parsing. \\
\hline \multicolumn{2}{|l|}{ ARABTAGS } \\
\hline Purpose of design & Standardizing and building a comprehensive Arabic tag set. \\
\hline $\begin{array}{l}\text { Main } \\
\text { characteristics }\end{array}$ & The tag set hierarchy follows the tradition of Arabic grammar. \\
\hline
\end{tabular}




\begin{tabular}{|c|c|}
\hline Tag set size & $\begin{array}{l}161 \text { detailed tags (101 nouns, } 50 \text { verbs, } 9 \text { particles, } 1 \text { punctuation mark } \\
\text { including } 28 \text { different POS general tags to cover the main part-of-speech } \\
\text { classes and sub-classes. }\end{array}$ \\
\hline $\begin{array}{l}\text { Morphological } \\
\text { features }\end{array}$ & Gender, Number, Case, Mood, Person, State \\
\hline Applications & Used in the Arabic Morphosyntactic Tagger AMT \\
\hline \multicolumn{2}{|c|}{ MorphoChallenge 2009 Qur'an gold standard tag set } \\
\hline Purpose of design & $\begin{array}{l}\text { To annotate the Qur'an gold standard to be used to evaluate } \\
\text { morphological analyzers in the MorphoChallenge } 2009 \text { competition. }\end{array}$ \\
\hline $\begin{array}{l}\text { Main } \\
\text { characteristics }\end{array}$ & $\begin{array}{l}\text { It was developed using the data for Morphological Tagging of the Qur'an } \\
\text { database. }\end{array}$ \\
\hline Tag set size & $\begin{array}{l}\text { The tag set involves combinations of the POS main and sub-classes and } \\
\text { the morphological features of the analysed words. }\end{array}$ \\
\hline $\begin{array}{l}\text { Morphological } \\
\text { features }\end{array}$ & $\begin{array}{l}\text { Gender, Number, Person, Case, Mood, Aspect, Voice, Definiteness, } \\
\text { Diptotic }\end{array}$ \\
\hline Applications & $\begin{array}{l}\text { Used to construct the Qur'an gold standard for evaluating morphological } \\
\text { analyzers in the MorphoChallenge } 2009 \text { competition. }\end{array}$ \\
\hline \multicolumn{2}{|c|}{ Quranic Arabic Corpus POS tag set } \\
\hline Purpose of design & $\begin{array}{l}\text { To annotate the Qur'an by morphological and part-of-speech tagging } \\
\text { information. }\end{array}$ \\
\hline $\begin{array}{l}\text { Main } \\
\text { characteristics }\end{array}$ & $\begin{array}{l}\text { Used Tim Buckwalter's morphological analyzer as initial tagging, then a } \\
\text { mapping from Buckwalter's tag set to the Quranic Arabic Corpus tag set. } \\
\text { It adapts traditional Arabic grammar. }\end{array}$ \\
\hline Tag set size & $\begin{array}{l}\text { The tag set involves combinations of the POS main and sub classes and } \\
\text { the morphological features of the analysed words. }\end{array}$ \\
\hline $\begin{array}{l}\text { Morphological } \\
\text { features }\end{array}$ & $\begin{array}{l}\text { Person, Gender, Number, Aspect, Mood, Voice, Verb form, Derivation, } \\
\text { State }\end{array}$ \\
\hline Applications & $\begin{array}{l}\text { Used in the morphological and part-of-speech annotation of the Quranic } \\
\text { Arabic Corpus. }\end{array}$ \\
\hline \multicolumn{2}{|c|}{ Columbia Arabic Treebank POS tag set } \\
\hline Purpose of design & $\begin{array}{l}\text { To be used for the part-of-speech annotation of Columbia Arabic } \\
\text { Treebank CATiB. }\end{array}$ \\
\hline $\begin{array}{l}\text { Main } \\
\text { characteristics }\end{array}$ & $\begin{array}{l}\text { CATiB avoids the annotation of redundant linguistic information that is } \\
\text { determinable automatically from syntax and morphological analysis, e.g., } \\
\text { nominal case. CATiB uses linguistic representation and terminology } \\
\text { inspired by the long tradition of Arabic syntactic studies. }\end{array}$ \\
\hline Tag set size & $\begin{array}{l}6 \text { part-of-speech tags (VRB - all verbs, VRB-PASS - passive-voice } \\
\text { verbs, NOM - all nominals, PROP - proper nouns, PRT - particles, } \\
\text { PNX - all punctuation marks) }\end{array}$ \\
\hline $\begin{array}{l}\text { Morphological } \\
\text { features }\end{array}$ & $\begin{array}{l}\text { No morphological features are encoded in the part-of-speech tag set of } \\
\text { Columbia Arabic Treebank CATiB. }\end{array}$ \\
\hline Applications & $\begin{array}{l}\text { Used in the part-of-speech annotation of Columbia Arabic Treebank } \\
\text { CATiB. }\end{array}$ \\
\hline
\end{tabular}




\section{Morphological features in tag set design criteria}

EAGLES $^{13}$ proposed recommendations (guidelines) for morphosyntactic categories for European languages. The aim of the EAGLES guidelines is to propose standards in developing tag sets for morphosyntactic tagging, in the interest of comparability, interchangeability and reusability of annotated corpora. In addition to preferred standards, EAGLES guidelines also cater for extensibility, allowing specifications to extend to language-specific phenomena. The guidelines proposed standardisation in three important areas:

1- Representation/Encoding: transparency, processability, brevity and unambiguity.

2- Identifying categories/subcategories/structure: agreement on common categories and allowance for variation (obligatory, recommended and optional specification).

3- Annotation schemes and their application to text: detailed annotation schemes should be made available to end-users and to annotators.

EAGLES recognizes four degrees of constraint in the description of word categories for morphosyntactic tags. First, obligatory: attributes have to be included in any morphosyntactic tag set (main categories of part-of-speech Noun, Verb, Adjective, Pronoun/Determiner, Article, Adverb, Adposition, Conjunction, Interjection, Unique/Unassigned, Residual, Punctuation). Second, recommended: attributes and values of widely-recognized grammatical categories which occur in conventional grammatical description (e.g. Gender, Number, Person, etc.). Third, generic special extensions: attributes and values which are not usually encoded, but might be included for particular purposes, for example semantic classes such as temporal nouns, manner adverbs, place names, etc. Finally, language-specific special extensions: additional attributes or values which may be important for a particular language.

Khoja et al. (2001) compared their Arabic tag set against the EAGLES guidelines. The comparison showed: first, EAGLES tag set guidelines are based on Latin as a common ancestor, while Arabic has some novel features not found in Latin, for example certain categories and subcategories that inherit properties from the parent categories. Second, a classical Arabic tag set has three main categories (nouns, verbs and particles), while EAGLES has eleven major part-of-speech categories. Third, apart from nouns and verbs, other major categories in EAGLES such as pronouns, numerals and adjectives are described as subcategories of major categories in a Classical Arabic tag set. Fourth, Arabic, not only has singular and plural numbers, but it also has dual number. Moreover, Arabic verbs are classified as being perfect, imperfect and imperative, which differs from EAGLES classification of past, present and future tenses. Finally, the mood morphological feature is not covered by the EAGLES guidelines.

Atwell (2008) proposed criteria for tag set development, and stated that there are dimensions (choices) to be made by developers of a new part-of-speech tag set. 
Developers must decide on the set of grammatical tags or categories, and their definitions and boundaries. These criteria were applied to Arabic when the ARABTAGS tag set (Alqrainy 2008) was designed. We followed the same criteria as Atwell (2008) in designing the general-purpose morphological features tag set. Sections 2.1-2.12 explain the criteria and how they are applied in the SALMA - Tag set.

\section{I Mnemonic tag names}

Generally, tag names for English PoS tag sets are chosen to help linguists to remember the grammatical categories such as CC for Coordinating Conjunction and VB for $\operatorname{Ver} \boldsymbol{B}$. The SALMA Tag Set for Arabic has to encode much richer morphology: the tag is represented by a string of 22 characters. Each character represents a value or attribute which belongs to a morphological feature category. The position of the character in the tag string is important as it identifies the morphological feature category. The value of the feature is represented by one lower case character, which is intended to remain readable, such as: $\mathbf{v}$ in the first position to indicate verb, $\mathbf{n}$ in the second position to indicate name, gender category values in the seventh position where masculine is represented by $\mathbf{m}$, feminine is represented by $\mathbf{f}$ and common gender is represented by $\mathbf{x}$. If the value of a certain feature is not applicable for the tagged word then dash '-' is used to indicate this. A question mark '?' indicates 'unknown': a certain feature normally belongs to the word but at the moment is not available or the automatic tagger could not guess it.

The interpretation of the tag is handled by referring to the attribute value and its position in the tag string. The position of the attribute in the tag string identifies the morphological feature category, while the attribute value is identified by searching the morphological feature category for the specified symbol. Then, all these single interpretations of attributes are grouped together to represent the full tag of the word. The tag is intended to remain readable by linguists. Moreover, the tag is straightforwardly readable by software, for example by a search tool matching specified feature-value(s).

\subsection{Underlying linguistic theory}

Linguists who develop new tag sets will inevitably be swayed by the linguistic theories they espouse. In the case of English, there is disagreement between grammar theories on the range of grammatical categories and features to be tagged, and more complicated structural issues. It is difficult to have theory-neutral annotation, because every tagging scheme makes some theoretical assumptions (Atwell 2008).

Khoja's mophosyntactic tag set was derived from classical Arabic grammar (Khoja et al. 2001; Khoja 2003). ARBTAGS also tried to follow the Arabic grammatical system, which is based upon main three part-of-speech classes: verbs, nouns and particles, and enriched with inflectional features (Alqrainy 2008). The Arabic Penn Treebank tag set follows the same criteria used to develop the English Treebank 
(Maamouri \& Bies 2004). ERTS (extended reduced tag set) extends the LDC reduced tag set (RTS) by adding morphological features namely (case, mood, definiteness, gender, number and person). This extends the 25 RTS tag set to 75 tag set of ERTS (Diab 2007).

The proposed SALMA Tag Set adds more fine-grained details to the existing tag sets. The tag set follows traditional Arabic grammar theory (Dahdah 1987; Dahdah 1993; Wright 1996; Al-Ghalayyni 2005; Ryding 2005) in specifying 22 morphological features categories and their attributes or values. Section 4 justifies the SALMA Tags in terms of this underlying theory.

\subsection{Classification by form or function}

For English an ambiguous word like 'open' is tagged according to its function, and only its inflected forms are tagged by their form. Arabic words are highly inflected and hence word classification tends to be dependent on form. Classification by form is dependent on the word, while classification by function is dependent on the function of the word in context. For Arabic, the word class is heavily constrained by form, but if there is only one analysis, then it is determined by function. If there are two analyses, one needs to take context into account which means it is partially determined by function. In this case the function has to be taken into account for classification.

Arabic word-class is dependent on form. Traditional Arabic grammar groups words according to their inflexional behaviour. A challenging characteristic of Arabic is the treatment of short vowels, which are normally omitted in written Arabic. These short vowels can help in specifying some morphological feature information of grammatical categories. The Qur'an is fully vowelized to ensure it is pronounced correctly. This makes the Qur'an a potential 'Gold Standard' corpus for Arabic tagging and NLP research (Atwell 2008).

Another challenge of Arabic words can appear when classifying words according to certain morphological features such as gender. Classifying nouns into masculine or feminine can be viewed from two perspectives. First, according to the word's structure or morphologically; masculine singular nouns are not normally marked by any suffix, while feminine nouns have a suffix - normally $-a^{h}$ - added at the end of the noun. Second, semantically; nouns are arbitrary classified into masculine or feminine, except when a noun refers to a human being or other creature having natural gender (sex), when it is normally conforms to natural gender (Ryding 2005). On rare occasions a noun has the 'morphological' feminine suffix $-a^{h}$, but indicates a male and is therefore

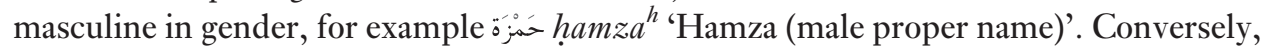
a few nouns which are feminine in gender do not have the 'morphological' feminine suffix $-a^{h}$, an example being مَرْيْم maryam 'Mary (female proper name).

\subsection{Idiosyncratic words}

Arabic has some words with special, idiosyncratic behaviour, such as particles which cannot be analysed morphologically according to a root and a pattern. Khoja, Garside 
et al (2001) includes examples of this type in an 'Exception' category, which covers group of particles that are equivalent to the English word 'except' and the prefixes non-, un- , and im-.

\subsection{Categorization problems}

A detailed categorisation scheme requires each tag to be defined clearly and unambiguously, by giving examples in a 'case-law' document. This definition should include how to decide difficult, borderline cases, so that all examples in the corpus can be tagged consistently. Many words can belong to more than one grammatical category, depending on context of use. Tagging schemes should specify how to choose one tag as appropriate, if a word can have different part-of-speech tags in different contexts (Atwell 2008).

Vowelized Arabic text has less ambiguity than non-vowelized Arabic text. Short vowels and some affixes add linguistic information, which reduces the ambiguity. In the SALMA Tag Set, each feature category is described, clearly documented and examples are provided. Moreover, tagging guidelines define the appropriate attribute for the morphological feature category.

\subsection{Tokenisation: what counts as a word?}

Arabic text tokenisation is not an easy task. Simple tokenisation of text can be carried out by dividing text into words by spaces, or punctuation. This tokenisation process is primitive and the first step in tokenising Arabic text. The majority of Arabic words are complex words; one or more clitics can be attached to the beginning and the end of the word [clitic(s) + word + clitic(s)]. These clitics are particles, pronouns or the definite article. A tag is provided for each clitic attached to a word along with the tag of the word. For instance, the word وَبَحَسنَكاتِهِ mabihasanātihim 'and with their good deeds', consists of four parts, the conjunction $g$ ma 'and', the preposition $y i$ 'with', the word حَسَنَّات hasanāti 'good deeds' and the pronoun هم ' word will be the tags of the four elements and the whole word tag which is a combination of the morpheme tags. The clitics will help the tagging scheme in identifying some of the morphological attributes; the preposition $ب$ bi governs the genitive case of the noun.

\subsection{Multi-word lexical items}

Multi-words lexical items are rare in Arabic (Alqrainy 2008). Such items might consist of two words; noun followed by adjective describing the preceding noun, some compound proper names such as فَبَّدُ اللَّabdu allāh 'Abdullah', or compound particles

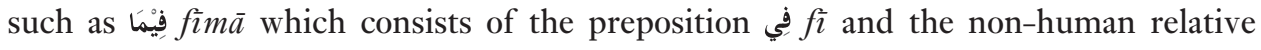
noun so $m \bar{a}$. In the case of proper names a single tag might be more appropriate, while, for the other cases, a separate tag for each part of the lexical item will give more morphological detail about the multi-word lexical items. 
The Penn Arabic Treebank guidelines ignore multi-word lexical items and tag each word of a compound word separately:

[...] Divided/compound proper names in Arabic (Abdul Ahmed, e.g.): Label all parts of the name with the 'Is a name' button.

Idioms: (for example, in what in them = 'included'): Label each word independently for its own part of speech (ignore the idiomatic meaning). ${ }^{14}$

\subsection{Target users and/or applications}

Fitness for purpose and customer satisfaction are the most important practical criteria for a new tag set. One common use of part-of-speech tagged corpora is language teaching and research. A detailed tag set is required in teaching and learning to reflect fine distinctions of grammar, even though Machine Learning systems could cope better with a smaller tag set. General-purpose tag set developers should be more aware of potential re-use: detailed and more sophisticated part-of-speech tag schemes allow wider re-use of the corpus in future research (Atwell 2008).

The SALMA Tag Set is a general-purpose tag set. It encodes detailed information of morphological features embedded in any word. This morphological features information enables the tag set to be widely re-used.

\subsection{Availability and/or adaptability of tagger software}

If a part-of-speech tag set is implemented in automatic tagger software, this has a clear advantage over a purely theoretical tag set (Atwell 2008). HMM taggers can be re-used for any language including Arabic. Experiments on highly inflectional languages such as German and Czech using an HMM tagger with a fine-grain tag set achieved higher tagging accuracy than two state-of-the-art general purpose part-of-speech taggers, The TnT tagger and SVMTool (Schmid \& Laws 2008). Another experiment that uses a fine-grain tag set was done for Latin. Latin words require morphological analysis of nine features: part-of-speech, person, number, tense, mood, voice, gender, case and degree. The experiment used the TreeTagger analyzer, which achieved an accuracy of $83 \%$ in correctly disambiguating the full morphological analysis (Bamman \& Crane 2008).

\subsection{Adherence to standards}

The EAGLES guidelines are designed for European languages. However, the Arabic language is different from Indo-European languages and has its own structure and morphological features. Instead, the standard adhered to in the SALMA Tag Set is that of traditional Arabic grammar books e.g. (Dahdah 1987; Dahdah 1993; Wright 1996; Al-Ghalayyni 2005; Ryding 2005). 


\section{II Genre, register or type of language}

The SALMA Tag Set is intended to be general-purpose and to be used in part-ofspeech tagging of different text types, formats and genres, of both vowelized and nonvowelized text. We plan to evaluate the tagging schemes and the tag set on variety of text types, formats and genres. Corpora can include text in classical Arabic such as the Qur'an, Classical Arabic dictionaries and poems from ancient Arabic literature, as well as Modern Standard Arabic text from newspapers, magazines, web pages, blogs, children's books, school text books, etc.

\subsection{Degree of delicacy of the tag set}

The total number of tags is an indicator of the level of fine-grainedness of analysis. Existing Arabic corpus tag sets have a degree of delicacy ranging from 25 for the RTS tag set of the Penn Arabic Treebank, to 75 tags for ERTS, 161 tags for ARABTAGS, and 177 tags for Khoja's tag set. The SALMA Tag Set is a fine-grain tag set. It is unfeasible to enumerate all possible tags that can be generated from valid combinations of the 22 morphological feature categories; however, we can count the attributes of each feature category, and use these to estimate an upper bound or limit on the degree of delicacy of the SALMA Tag Set. Section 4 discusses four selected examples of the 22 morphological features of the SALMA Tag Set and their attributes.

An upper limit of possible feature combinations is $4.07 \mathrm{E}+16$, the total number of possible combinations of features in the SALMA Tag Set of Arabic, calculated by multiplying together the number of attributes of each of the 22 morphological features. But, of course, this includes many invalid tags that will never be used. A more realistic upper bound is given by counting the possible feature combinations for each major part of speech, and summing these. Table 2 shows the absolute upper limit of possible feature combinations for each major part of speech (Noun, Verb, Particle, Other (Residual), and Punctuation); this gives an upper limit of 101,945,168 possible morphological feature combinations: about one hundred million possible SALMA tags.

\section{The Complex morphology of Arabic}

Most Arabic words are derived from their roots following certain templates called patterns. The derivation process adds prefixes, suffixes and infixes to the root letters to generate a new word, which has a new function or meaning but preserves the main concept or meaning carried by the root. Moreover, using the derived word in a certain context will require clitics to be added to the beginning and the end of the word. Proclitics include prepositions, conjunctions and definite articles, and enclitics include pronouns. In addition, one or more affixes or clitics can be added to the derived word. In conclusion, most Arabic words are complex words consisting of multiple morphemes. 
Table 2. The upper limit of possible combinations of SALMA features.

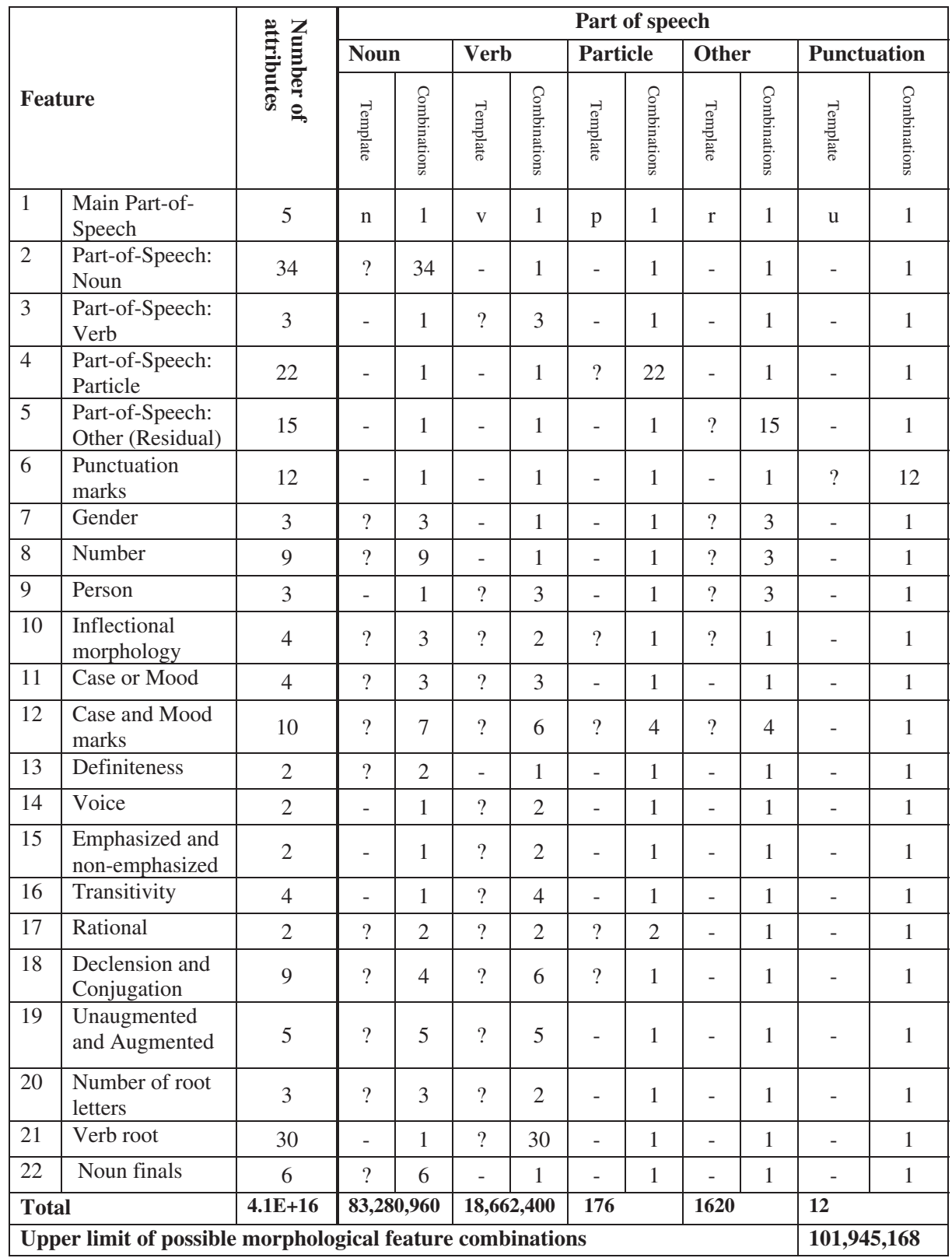

To specify a word's morphemes, tokenization is needed to analyse the word morphemes as clitics, affixes or stem. For example the tokenizer will specify the morphemes of the word وسيكتبونا masayaktubūnahā 'and they will write it' as follows: preclitic $9 m a$ 'and' (conjunction), prefixes wa 'will' and sa (imperfect prefix), the 


\begin{tabular}{|c|c|c|c|}
\hline \multicolumn{2}{|c|}{ Analyzed sentence: } & \multicolumn{2}{|c|}{$\begin{array}{l}\text { أقمت بمدينتي الجديدة لمدة عامئ 'aqamtu bimadīnatī al-ğgadìdat } \\
\text { limuddat 'ámayn "I have stayed in my new city for two } \\
\text { years" }\end{array}$} \\
\hline \multicolumn{2}{|c|}{ Analyzed word: } & \multicolumn{2}{|l|}{ بمدينتي bimadīnatī in my city } \\
\hline \multicolumn{4}{|c|}{ Step 1 : Tokenization of words into morphemes } \\
\hline Word & Proclitics & prefixes & enclitics \\
\hline بملينتي & bi in & مدين madīna city & $\begin{array}{l}ت(\text { () } t \text { feminine } \bar{l} \text { my } \\
t \bar{a} \text { s }\end{array}$ \\
\hline \multicolumn{4}{|c|}{ Step 2 : Assign morpheme tags } \\
\hline \multicolumn{2}{|c|}{ Morpheme } & Tag & Description \\
\hline \multicolumn{2}{|c|}{ $b i$ in } & p--p---------------- & Particle; Preposition \\
\hline \multicolumn{2}{|c|}{ مدين madīna city } & nl-------vg?i----tat-s & $\begin{array}{l}\text { Noun; Noun of place; Varied; } \\
\text { Genitive; Indefinite; Primitive/ } \\
\text { Concrete noun; Augmented by one } \\
\text { letter; Triliteral root; Sound noun. }\end{array}$ \\
\hline \multicolumn{2}{|c|}{$\because t$ feminine $t \bar{a}$} & $r---f-f s-s-k--------$ & $\begin{array}{l}\text { Other (Residual); } t \bar{a}^{\prime} \text { of } \\
\text { femininization; feminine; Singular; } \\
\text { Invariable; } \text { kasra }^{h} \text {; }\end{array}$ \\
\hline \multicolumn{2}{|c|}{ ي } & r---r-msfsgs--------- & $\begin{array}{l}\text { Other (Residual); Connected } \\
\text { pronoun; Common gender; Singular; } \\
\text { First person; Invariable; Genitive; } \\
\text { sukūn (Silence) }\end{array}$ \\
\hline \multicolumn{4}{|c|}{ Step 3: Assign word tag } \\
\hline \multicolumn{2}{|l|}{ Word } & Tag & Description \\
\hline 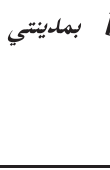 & bimadīnatī & 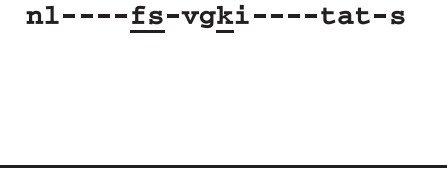 & $\begin{array}{l}\text { Noun; Noun of place; feminine; } \\
\text { Singular; Declined; Genitive; } \\
\text { kasra }^{h} \text {; Indefinite; Primitive/ } \\
\text { Concrete noun; Augmented by one } \\
\text { letter; Triliteral root; Sound noun. }\end{array}$ \\
\hline
\end{tabular}

Figure 12. Example of tokenization, the SALMA tag assignment for separate morphemes and the combination of the morpheme tags into the word tag.

stem (i.e. lemma) كتب kataba 'write', the suffix ون ūn 'they' and the enclitic to hāa 'it' (object suffixed pronoun). The word consists of 6 morphemes. Each morpheme carries morphological features and belongs to a specific part of speech category. Our SALMA Tag Set assigns a tag to each morpheme of the word. Then the morphemes' tags are combined into one word tag. The word tag inherits its morphological feature attributes using an algorithm that establishes agreements on morphological feature attributes. The description of the algorithm is beyond the scope of this paper. This paper is about the output of the tagger rather than describing the algorithm of tagging and combining morpheme tags into word tags. The following example in figure 12 shows the tokenization of the word into morphemes, the assignment of the part of speech tag for each morpheme and the result of combining the morpheme tags into one whole word tag. Tokenization is a well-known problem even for English corpus tagging. 
The tagged LOB corpus defines the word or graphic word as a sequence of characters surrounded by spaces (or punctuation marks). Each word is assigned a tag. Differences in tagging occur due to: 1. variation in segmentation of compound terms, as in: fancy free given the tags NN (noun, singular, common) JJ (adjective), and fancy-free given the tag $\mathbf{J J}$ (adjective); 2. hyphenated sequences, as in: an abovethe-rooftops position given the tag JJB (adjective, attributive-only); 3. syntactic boundaries, as in: Henry NP (noun, singular, proper) 8's CD\$ (numeral, cardinal, genitive) hall. In some cases, the LOB Corpus tagging guidelines have changed from 'one-word-one-tag-approach' to idiom tagging to handle the cases of recurrent multiword sequences functioning as units (Johansson, Atwell, Garside \& Leech 1986).

On the other hand, contractions forming regular patterns such as, I'll, she's, fohn's, let's, d'you, etc. are split up in the tagged LOB corpus as the following: I' ll, she' s, fohn' $s$, let' $s, d^{\prime}$ you. Each part is treated as a separate word and assigned a single tag. Except where 's is possessive suffix, then the word gets a single tag entry $\$$ e.g. Fohn's gets the tag NP\$ (Johansson et al. 1986).

\section{The standard tag set expounding morphological features}

The SALMA tag set is a general-purpose fine-grained tag set. It is intended that this tag-set will be used by part-of-speech tagging software to annotate corpora with detailed morphological information for each word, and to enable direct comparisons between tagging algorithms and taggers using the same tag set. The tag set has been designed by grouping 22 morphological feature categories in one tag. Most of these morphological categories are described in any traditional Arabic language grammar book. In our study, all the morphological features are attested in five well-known traditional Arabic grammar books (Dahdah 1987; Dahdah 1993; Wright 1996; Al-Ghalayyni 2005; Ryding 2005). Table 3 shows the 22 morphological feature categories.

The tag string consists of 22 characters. Each character represents a value or attribute which belongs to a morphological feature category. The position of the character in the tag string is important to identify the morphological feature category. Each morphological feature category attribute is represented by one lower case letter, which is still human-readable, such as $\mathbf{v}$ in the first position to indicate verb, $\mathbf{n}$ in the second position to indicate name, gender category values in the seventh position: masculine represented by $\mathbf{m}$, feminine represented by $\mathbf{f}$ and common gender represented by $\mathbf{x}$. If the value of a certain feature is not applicable for the word, then a dash '-' is used to indicate this; e.g. the mood morphological feature is not a noun feature. In contrast, a question mark '?' means a certain feature belongs to a word but, at the moment, the feature value is not available or the automatic tagger could not guess it.

The tag is intended to remain readable by linguists. Moreover, it can be rendered more readable if the interpretation of the tag string features is generated automatically: software can convert each position + letter to a human-readable English and/or Arabic 
Table 3. Arabic Morphological Feature Categories.

\begin{tabular}{|c|c|c|c|}
\hline Position & Morphological Features & Categories & \\
\hline 1 & Main Part-of-Speech & أقَقسام الكلام الرئيسيَّة & 'aqsām al-kalām ar-ra'īsiyya ${ }^{t}$ \\
\hline 2 & Part-of-Speech: Noun & أقسام الكلام الفرعيَّة (الاسم) & 'aqsām al-kalām al-far 'iyya' (al-'ism) \\
\hline 3 & Part-of-Speech: Verb & أقسام الكلام الفرعيَّة (الفعل) & 'aqsām al-kalām al-far 'iyya (al-fi'l) \\
\hline 4 & Part-of-Speech: Particle & أقسام الكلام الفرعيَّة (الحرف) & 'aqsām al-kalām al-far 'iyya' (al-ḥarf) \\
\hline 5 & $\begin{array}{l}\text { Part-of-Speech: Other } \\
\text { (Residual) }\end{array}$ & أقسام الكلام الفرعيَّة (أخرى) & 'aqsām al-kalām al-far 'iyya' ('uhrrā) \\
\hline 6 & Punctuation marks & 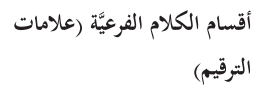 & $\begin{array}{l}\text { 'aqsām al-kalām al-far 'iyya' ('alāmāt } \\
\text { at-tarqīm) }\end{array}$ \\
\hline 7 & Gender & المُذَكَّر والمُؤَنَّث & al-mudakkar wa al-mu'annat \\
\hline 8 & Number & 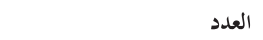 & al-'adad \\
\hline 9 & Person & الاسناد & al-'isnād \\
\hline 10 & Inflectional morphology & الصَّرف & aș-șarf \\
\hline 11 & Case or Mood & الحالة الإعرابية للاسم أو الفعل & $\begin{array}{l}\text { al-hāala }{ }^{t u} \text { al-'i'rābiyya }{ }^{\text {tu }} \text { lil-'ism 'aw al- } \\
\text { fi l }\end{array}$ \\
\hline 12 & Case and Mood marks & علامة الإعراب أو البناء & 'alāmāt al-'írāb wa al-binā' \\
\hline 13 & Definiteness & المَعْفَةَ والنَّكرَة & al-ma'rifa ${ }^{t i}$ wa an-nakira ${ }^{t i}$ \\
\hline 14 & Voice & 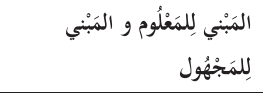 & $\begin{array}{l}\text { al-mabnì lil-ma'līm wa al-mabnì lil- } \\
\text { mağhūul }\end{array}$ \\
\hline 15 & $\begin{array}{l}\text { Emphasized and non- } \\
\text { emphasized }\end{array}$ & المُؤَكَّد وغيرُ المُؤَكُد & al-mu'akkad wa ḡayr al-mu'akkad \\
\hline 16 & Transitivity & 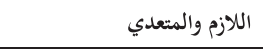 & al-lāzim wa al-muta'addi \\
\hline 17 & Rational & 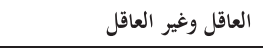 & al- 'āqil wa ḡayr al- 'āqil \\
\hline 18 & $\begin{array}{l}\text { Declension and } \\
\text { Conjugation }\end{array}$ & التَّصريف & at-tașrīf \\
\hline 19 & $\begin{array}{l}\text { Unaugmented and } \\
\text { Augmented }\end{array}$ & المجرَّد والمزيد & al-muğarrad wa al-mazìd \\
\hline 20 & Number of root letters & عَدَد أحْرُف الجَذْر & 'adad 'ahruf al-ğgadr \\
\hline 21 & Verb root & 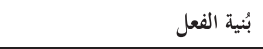 & bunya $^{\text {tu }}$ al-fi'l \\
\hline 22 & Noun finals & أقسام الأسم تبعاً للفظ آخره & 'aqsām al-'ismi tib ${ }^{\text {can }}$ li-lafẓi 'āhirhi \\
\hline
\end{tabular}

grammar term. Figures 13 and 14 show samples from the Penn Arabic Treebank and the Qur'an (the same sentences from section 1.4), tagged using the SALMA Tag Set.

The categories and features are drawn from traditional Arabic grammar books (Dahdah 1987; Dahdah 1993; Wright 1996; Al-Ghalayyni 2005; Ryding 2005). In most cases there is agreement among them, but in some cases there are discrepancies. When there is agreement, the approach taken is simply a matter of presenting the agreed features. When there is a discrepancy in most cases the difference is that one text has more fine-grained subcategories which are merged in other texts; so the more finegrained wider sub-classification is adopted. The only significant disagreement is in the 


\begin{tabular}{|c|c|c|c|c|}
\hline Word & & Morphemes & & Tag \\
\hline $\begin{array}{l}\text { wa waașșayna } \\
\text { And we have } \\
\text { enjoined }\end{array}$ & وَوَصَّينًَا & 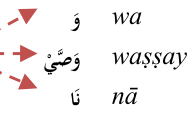 & $\begin{array}{l}\text { And } \\
\text { Have enjoined } \\
\text { We }\end{array}$ & $\begin{array}{l}\text { p--c---n------------- } \\
v-p---m p f s-s-a m o h v t t \&- \\
r---r-x p f s-s----h n----\end{array}$ \\
\hline $\begin{array}{l}\text { al-'insāna } \\
\text { (on) man }\end{array}$ & الإِنسَانَ & $\begin{aligned} & \text { al- } \\
\text { إنستَانَ } & \text { 'insāna }\end{aligned}$ & $\begin{array}{l}\text { The } \\
\text { Man }\end{array}$ & $\begin{array}{l}\text { r--d---1- } \\
\text { nq----ms-pafd---htbt-s }\end{array}$ \\
\hline $\begin{array}{l}\text { bi-wālidayhi } \\
\text { His parents }\end{array}$ & بِوَالِدَيْهِ & 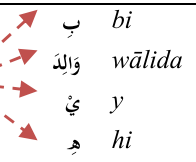 & $\begin{array}{l}\text { To } \\
\text { Parents } \\
\text { Both } \\
\text { His }\end{array}$ & $\begin{array}{l}\text { p--p---n- } \\
\text { nu----md-vgki---htot-s } \\
\text { r---r-xdts-s--------- } \\
\text { r---r-msts-k---------- }\end{array}$ \\
\hline $\begin{array}{l}\text { husn }^{a n} \\
\text { Kindness }\end{array}$ & حُنَnَ & $\begin{aligned} \rightarrow & \text { husn } \\
i & \text { an }\end{aligned}$ & Kindness & $\begin{array}{l}\text { ng----ms-vafi---ndst-s } \\
\text { r---k------f---------- }\end{array}$ \\
\hline
\end{tabular}

Figure 13. Sample of tagged vowelized Qur'an text using the SALMA Tag Set.

number of nouns; see section 4.2, and in that case we adopted the widest most finegrained sub-classification system.

Arabic grammar terms used to describe the attributes of the morphological feature categories in the SALMA - Tag Set are the same terms used by traditional Arabic grammar. The equivalent English translations of these grammar terms were extracted from 4 well-known traditional Arabic grammar reference books written in English. These books are: (Wright 1996), (Ryding 2005), (Dahdah 1993) and (Cachia 1973). These reference books agree on translating general Arabic grammar terms such as, noun, verb, adjective, person, number, case and mood. However, these reference books do not agree on translating some fine-grained attribute names such as as-sālim, which is translated into 'the strong verb' by Wright (1996), 'regular (sound) root' by Ryding (2005), 'intact verb' by Dahdah (1993), and 'sound verb; strong verb; verbum firmum' by Cachia (1973). The agreed English translations of the grammar terms were directly used. For the non-agreed English translation, Professor James Dickins (head of Arabic and Middle Eastern Studies, University of Leeds, UK) was consulted to give advice on those English translations of Arabic grammar terms that would be clearest to English speaking linguists.

Appendix A lists the morphological features categories and their attribute values at each position of the 22 positions of the tag string.

The following sections 4.1 to 4.4 describe four morphological categories selected to show examples of the detailed descriptions of the morphological categories and their attributes. The first selected category is the main part-of-speech. The second category is the part-of-speech subcategories of Noun; representing a detailed example of the subcategories of the main part-of-speech. Gender is selected to show an example of the morphological features of Arabic words. Finally, the morphological feature of Augmented and Unaugmented is selected to as an example of the word's internal structure features. The complete description of the 22 morphological features can be found in the annotation manual ${ }^{15}$ of the morphological features tag set of Arabic. The complete description also appears in Sawalha (2011). 


\begin{tabular}{|c|c|c|c|c|}
\hline Word & & Mor & eme & Tag \\
\hline $\begin{array}{l}\text { tamma } \\
\text { Accomplished }\end{array}$ & 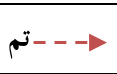 & تح & tamma Accomplished & v-p---msts-f-amihdstb- \\
\hline $\begin{array}{l}i^{\prime} d \bar{a} d u \\
\text { Preparing }\end{array}$ & عداد & اعداد & 'i'dādu Preparing & ng----ms-vndi---?db3-s \\
\hline $\begin{array}{l}\text { al-watā'iqa } \\
\text { Documents }\end{array}$ & وثائق & و ال ائق & $\begin{array}{l}\text { al The } \\
\text { watā'iqa Documents }\end{array}$ & 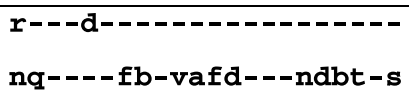 \\
\hline $\begin{array}{l}\text { al-mutawaffira }{ }^{t i} \\
\text { Available }\end{array}$ & & متوفر - م & $\begin{array}{l}\text { al The } \\
\text { mutawaffira } \\
\text { Available } \\
t i\end{array}$ & 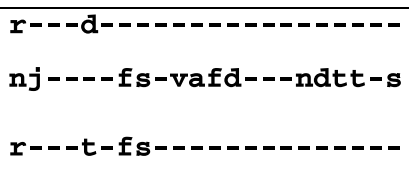 \\
\hline $\begin{array}{l}\text { bi katratin } \\
\text { In Many }\end{array}$ & & كثر & $\begin{array}{l}\text { bi In } \\
\text { katra Many } \\
\text { tin }\end{array}$ & 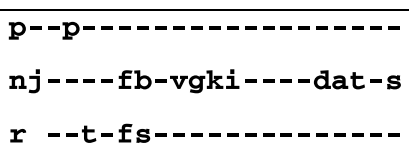 \\
\hline hawla About & حول & حول & hawla About & nv----m--s-fi----nst-s \\
\hline 'awwali First & 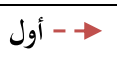 & أول & 'awwali First & n+----ms-vgki----dst-s \\
\hline riḥla ${ }^{t i}$ Trip & & & rihla Trip & $\begin{array}{l}\text { no----fs-vgki----dat-s } \\
\text { r---t-fs-------------- }\end{array}$ \\
\hline $\begin{array}{l}\text { tayyarānin } \\
\text { Flight }\end{array}$ & 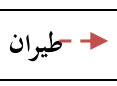 & 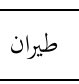 & tayyarānin Flight & ng----ms-vgki----dbt-s \\
\hline $\begin{array}{l}\text { utmāniyya }{ }^{t} \\
\text { Ottomani }\end{array}$ & & عثمان & $\begin{array}{l}\text { utmān Ottoman } \\
\text { iyya } \\
{ }^{t} \text { tā' marbūṭa }{ }^{\mathrm{h}}\end{array}$ & 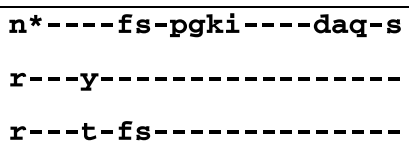 \\
\hline fawqa Over & 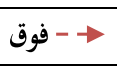 & فوق & fawqa Over & nv----m--s-fi---nst-s \\
\hline $\begin{array}{l}\text { al-bilādi } \\
\text { Countries }\end{array}$ & لاد & بلاد & $\begin{array}{ll}\text { al } & \text { The } \\
\text { bilād } & \text { Countries }\end{array}$ & $\begin{array}{l}\text { r---d----------------- } \\
\text { nl----mb-vgkd---ndat-s }\end{array}$ \\
\hline $\begin{array}{l}\text { al-'arabiyyati } \\
\text { Arabian }\end{array}$ & $\dot{y}$ & عرب & $\begin{array}{l}\text { al The } \\
\text { 'arab Arab } \\
\text { iyya } \\
\text { 'i tà' marbūṭa }{ }^{\mathrm{h}}\end{array}$ & 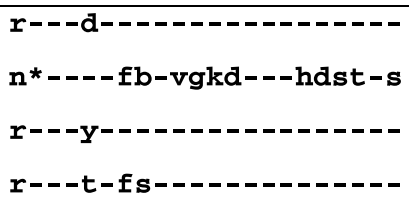 \\
\hline
\end{tabular}

Figure 14. Sample of tagged non-vowelized newspaper text using the SALMA Tag Set.

\section{I Main part of speech categories}

Generally, there is agreement among existing Arabic tag sets on the classification of main part-of-speech categories in traditional Arabic grammar books (e.g. Dahdah 1987; Dahdah 1993; Wright 1996; Al-Ghalayyni 2005; Ryding 2005; ALECSO 2008). Arabic language scholars classify Arabic words into three main part-of-speech categories: namely nouns, verbs and particles. Khoja's tag set added categories of 


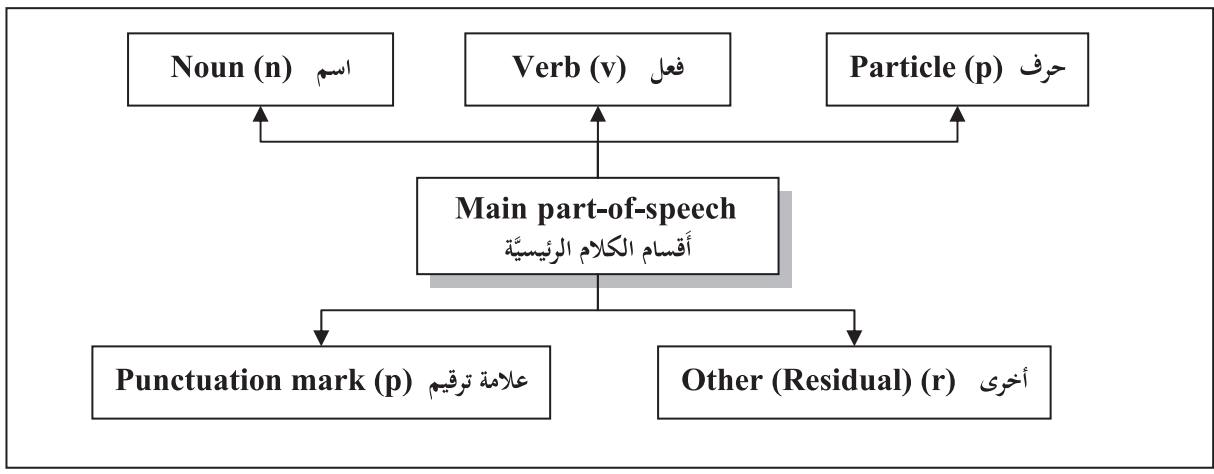

Figure 15. Main part-of-speech category attributes and letters used to represent them at position 1 .

punctuation marks and residuals. The punctuation marks used in Arabic are $(!:: ९-$. .). Others (residuals) include other non-Arabic words appearing in the text such as currency, numbers or words in other languages. Figure 15 lists the attributes of the main part-of-speech category, which occupies the first character in the tag string.

\subsection{Part-of-speech subcategories of noun}

A noun is defined as a word that has complete meaning and no tense associated with it. The Arabic concept of complete meaning corresponds approximately to content words except that it also includes pronouns. Traditional Arabic grammar uses the concept of meaning to separate nouns and verbs from particles. This is roughly equivalent to content vs. function or lexical vs. grammatical in contemporary lexical terminology. This is not an exact correspondence since pronouns - a grammatical category - are a sub class of nouns. Arabic linguists distinguish many kinds of nouns. According to Dahdah (1987) nouns are classified into 21 kinds. Other classifications overlap. We classified nouns into 34 different types. Table 4 shows the 34 different types of nouns and examples of each type. Figure 16 shows the classification attributes of the noun part-of-speech category, which occupies the second character in the tag string.

\subsection{Morphological feature of gender}

Arabic classifies nouns according to gender into three classes: ${ }^{16}$ nouns which are only

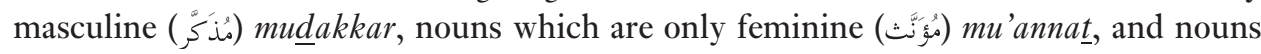
which are both masculine and feminine (common gender or neuter gender)

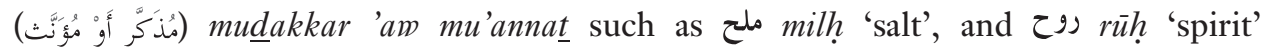
(Wright 1996). Figure 17 shows the morphological feature of gender subcategories. Table 5 lists the 3 subcategories, with examples of masculine, feminine and common 
Table 4. Noun types as classified by Arabic grammar scholars.

\begin{tabular}{|c|c|c|c|}
\hline & Noun types & $\mathbf{T}$ & Meaning and Examples \\
\hline $\begin{array}{ll} \\
\end{array}$ & $\begin{array}{l}\text { Gerund / verbal noun } \\
\text { المصدر al-mașdar }\end{array}$ & g & $\begin{array}{l}\text { A noun which indicates a case or an action that is not } \\
\text { related to time or tense. E.g. 'ف farah } h^{u n} \text { 'happiness'. }\end{array}$ \\
\hline 2 & $\begin{array}{l}\text { Gerund / verbal noun with } \\
\text { initial mìm } \\
\text { المصدر الميمي } \\
\text { al-maṣdar al-mìmi }\end{array}$ & m & 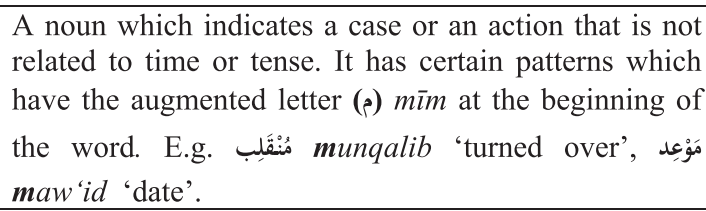 \\
\hline 3 & $\begin{array}{l}\text { Gerund of instance } \\
\text { مصدر المرَّة } \\
\text { mașdar al-marra }\end{array}$ & $\mathbf{0}$ & 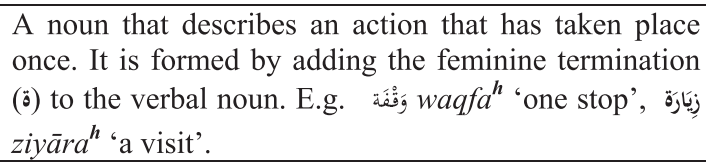 \\
\hline 4 & 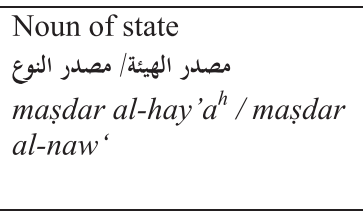 & $\mathbf{s}$ & 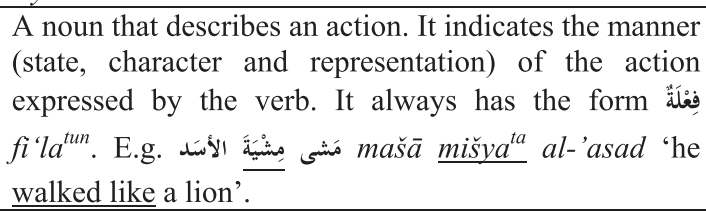 \\
\hline 5 & $\begin{array}{l}\text { Gerund of emphasis } \\
\text { مصدر التوكيد } \\
\text { mașdar al-tawkìd }\end{array}$ & e & 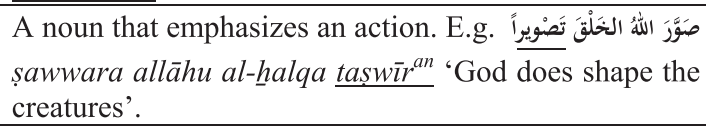 \\
\hline 6 & $\begin{array}{l}\text { Gerund of profession } \\
\text { المصدر الصناعي } \\
\text { al-mașdar al-sinin' }{ }^{\prime} \bar{l}\end{array}$ & $\mathbf{i}$ & 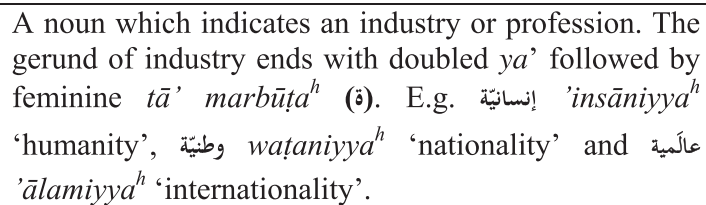 \\
\hline 7 & $\begin{array}{l}\text { Pronoun } \\
\text { الضمير } \\
\text { al-damir }\end{array}$ & $\mathbf{p}$ & 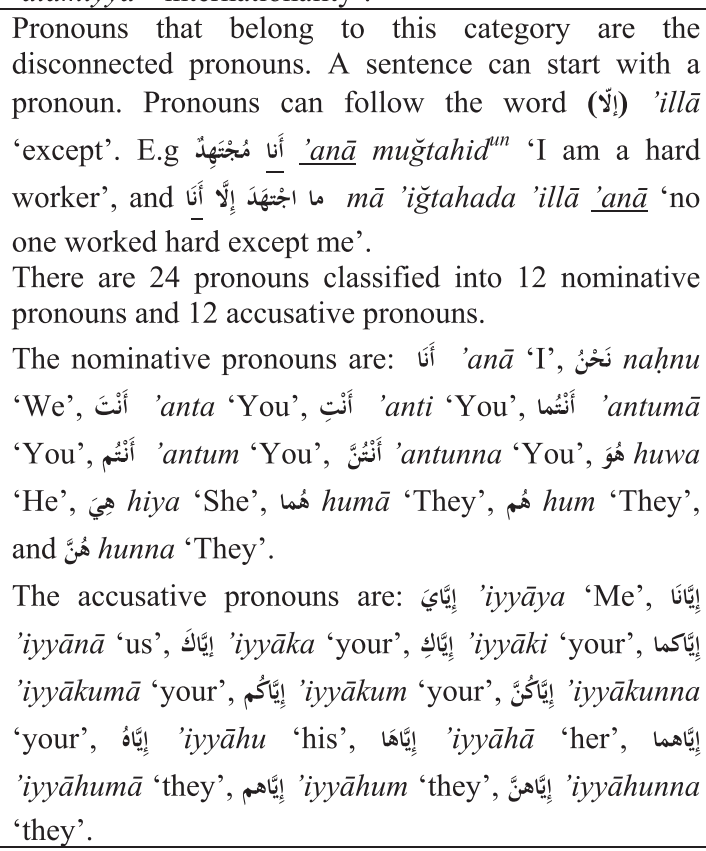 \\
\hline
\end{tabular}




\begin{tabular}{|c|c|c|c|}
\hline & oun types & $\mathbf{T}$ & Meaning and Examples \\
\hline 8 & $\begin{array}{l}\text { Demonstrative pronoun } \\
\text { اسم الإشارة 'ism al-'išărah }\end{array}$ & d & 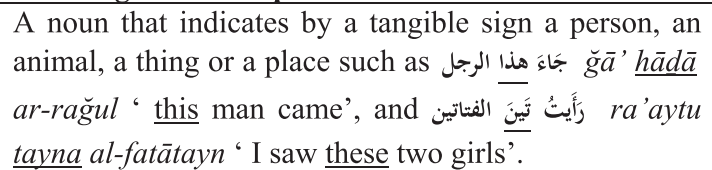 \\
\hline 9 & 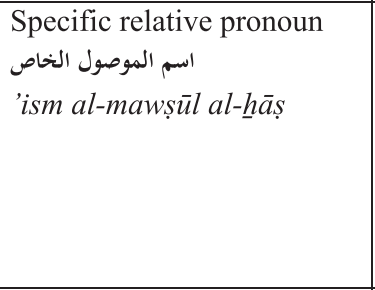 & $\mathbf{r}$ & $\begin{array}{l}\text { A group of nouns that connect two sentences to give a } \\
\text { full meaning. The special relative pronouns are } \\
\text { affected by three morphological feature categories, } \\
\text { number, gender and humanness. E.g. النّي al-lad } \bar{\imath} \text { 'who' } \\
\text { is a singular masculine human pronoun; اللواتي al-latī } \\
\text { 'who' is a singular feminine human pronoun; } \\
\text { lawātì 'who' is a plural feminine human pronoun. }\end{array}$ \\
\hline 10 & $\begin{array}{l}\text { Non-specific relative } \\
\text { pronoun } \\
\text { 'ism al-mawș̣̂l al-muštarak }\end{array}$ & c & 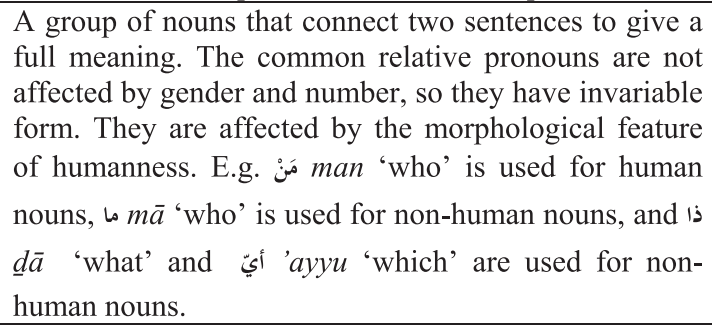 \\
\hline 11 & $\begin{array}{l}\text { Interrogative pronoun } \\
\text { اسم الاستفهام } \\
\text { 'ism al-'istfhām }\end{array}$ & b & 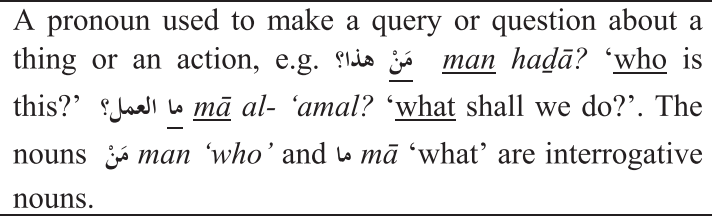 \\
\hline 12 & $\begin{array}{l}\text { Conditional noun } \\
\text { اسم الشرط } \\
\text { 'ism al-šart }\end{array}$ & $\mathbf{h}$ & 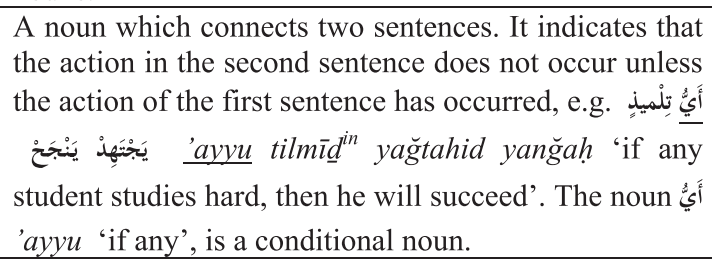 \\
\hline 13 & $\begin{array}{l}\text { Allusive noun } \\
\text { al-kināy } a^{h}\end{array}$ & $\mathbf{a}$ & 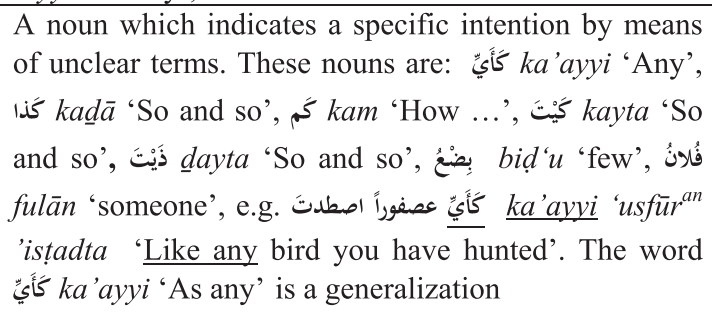 \\
\hline 14 & $\begin{array}{l}\text { Adverb } \\
\text { الظَّرف } \\
a z \text {-žarf }\end{array}$ & $\mathbf{v}$ & $\begin{array}{l}\text { A noun which indicates the time or place of the action. } \\
\text { It incorporates into its overall meaning a sence of } \\
\text { relative locality on time or place, e.g. hina 'when', } \\
\text { مُدام } m u d d a^{t u} \text { 'at a period of', and 'straight } \\
\text { forward (direction)' }\end{array}$ \\
\hline
\end{tabular}




\begin{tabular}{|c|c|c|c|}
\hline & Noun types & $\mathbf{T}$ & Meaning and Examples \\
\hline 15 & $\begin{array}{l}\text { Active participle } \\
\text { اسم الفاعل } \\
\text { 'ism al-fā'il }\end{array}$ & $\mathbf{u}$ & $\begin{array}{l}\text { A form that describes the doer of the action. This noun } \\
\text { is derived from the action or the verb itself. } \\
\text { E.g. كَاتِبَ katitib 'writer'. This noun is derived from the } \\
\text { action of writing or the verb write kaba. }\end{array}$ \\
\hline 16 & 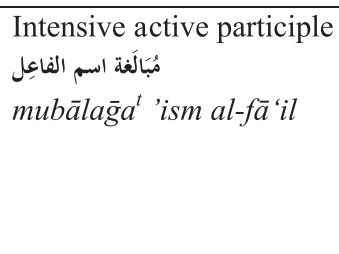 & $\mathbf{w}$ & 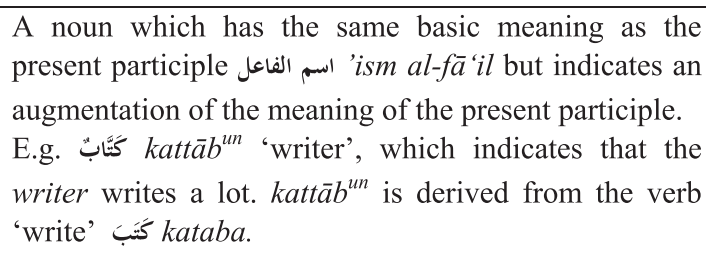 \\
\hline 17 & $\begin{array}{l}\text { Passive participle } \\
\text { اسم المفعول } \\
\text { 'ism al-maf'ūl }\end{array}$ & $\mathbf{k}$ & 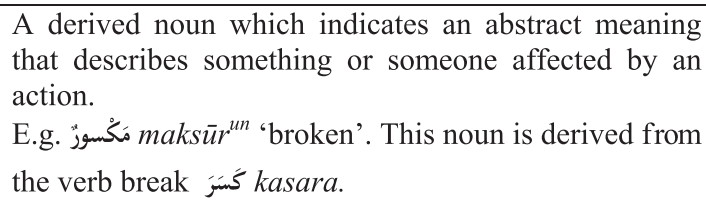 \\
\hline 18 & $\begin{array}{l}\text { Adjective } \\
\text { الصَّفة المشبَّهة } \\
a s ̣-s i f a^{h} a l-m u s ̌ a b b a h a^{h}\end{array}$ & $\mathbf{j}$ & 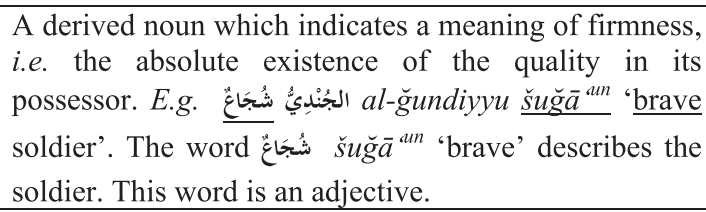 \\
\hline 19 & $\begin{array}{l}\text { Noun of place } \\
\text { 'ism al-mkān }\end{array}$ & I & 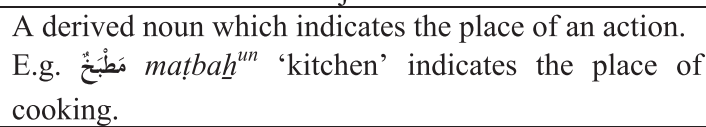 \\
\hline 20 & $\begin{array}{l}\text { Noun of time } \\
\text { اسم زمان 'ism zamōn }\end{array}$ & $\mathbf{t}$ & 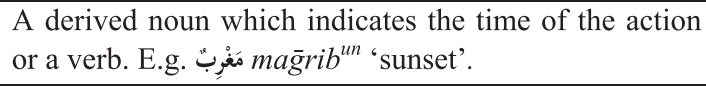 \\
\hline 21 & $\begin{array}{l}\text { Instrumental noun } \\
\text { اسم الآلة } \\
\text { 'ism al-'ālah }\end{array}$ & $\mathbf{z}$ & 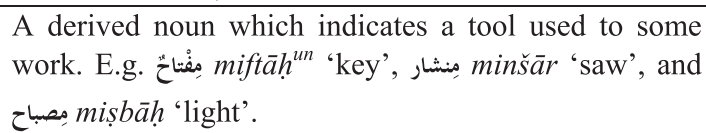 \\
\hline 22 & $\begin{array}{l}\text { Proper noun } \\
\text { 'ism al-' 'alam }\end{array}$ & $\mathrm{n}$ & 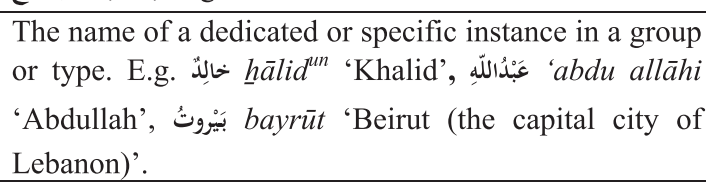 \\
\hline 23 & $\begin{array}{l}\text { Generic noun } \\
\text { اسم الجنس } \\
\text { 'ism al-ğins }\end{array}$ & $q$ & 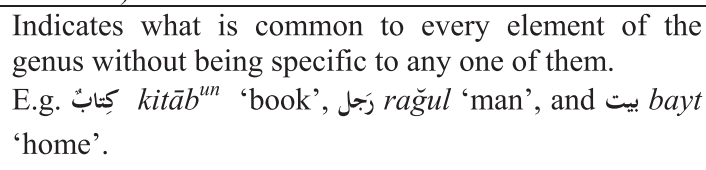 \\
\hline 24 & $\begin{array}{l}\text { Numeral } \\
\text { 'ism al-'adad }\end{array}$ & + & 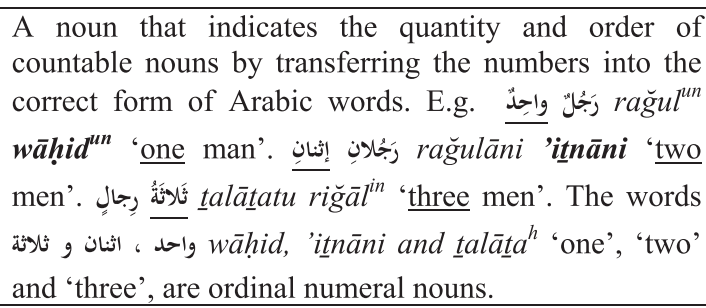 \\
\hline
\end{tabular}




\begin{tabular}{|c|c|c|c|}
\hline & Noun types & $\mathbf{T}$ & Meaning and Examples \\
\hline 25 & $\begin{array}{l}\text { Verb-like noun } \\
\text { اسم الفعل } \\
\text { 'ism al-fi 'il }\end{array}$ & $\&$ & 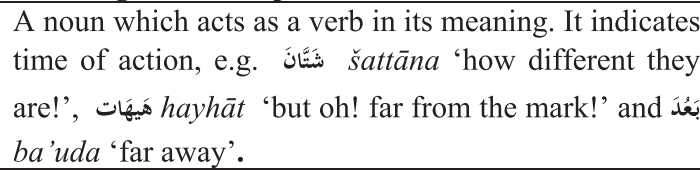 \\
\hline 26 & $\begin{array}{l}\text { The five nouns } \\
\text { al-'asmāa' al-hamsa }{ }^{h}\end{array}$ & f & 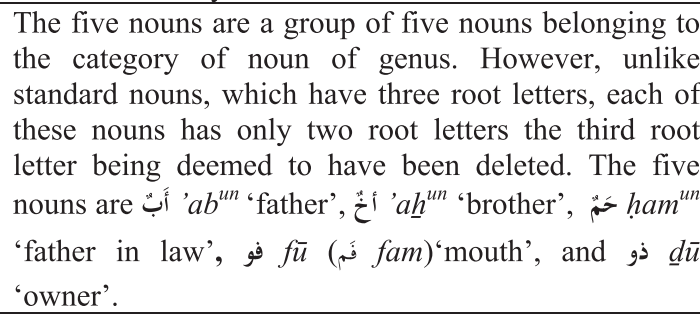 \\
\hline 27 & $\begin{array}{l}\text { Relative noun } \\
\text { اسم منسوب } 1 \text { 'ism mansūb }\end{array}$ & $*$ & 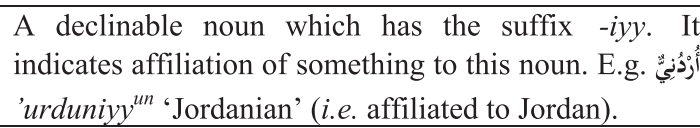 \\
\hline 28 & $\begin{array}{l}\text { Diminutive } \\
\text { اسم تصغير } \\
\text { 'ism tașgìir }\end{array}$ & $\mathbf{y}$ & 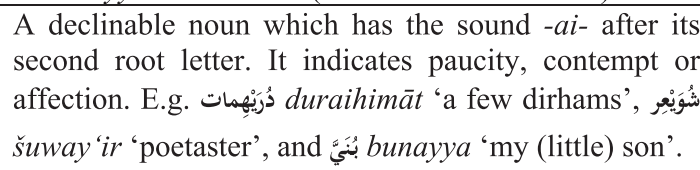 \\
\hline 29 & $\begin{array}{l}\text { Form of exaggeration } \\
\text { صيغة مبالغة } \\
s \bar{l} \bar{g} a^{t} a l-m u b \bar{a} l a \bar{g} a^{h}\end{array}$ & $\mathbf{x}$ & 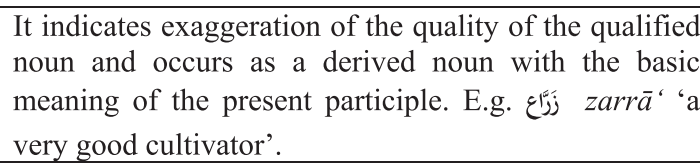 \\
\hline 30 & $\begin{array}{l}\text { Collective noun } \\
\text { اسم جمع 'ism ğam' }\end{array}$ & $\$$ & 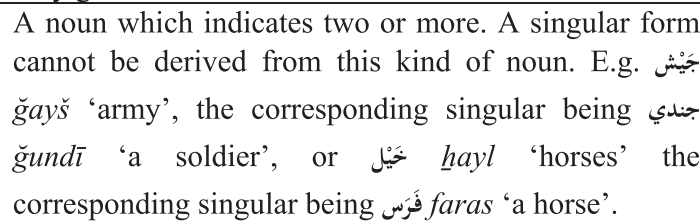 \\
\hline 31 & $\begin{array}{l}\text { Plural collective noun } \\
\text { اسم جنس جمعي } 2 \text { 'ism ğins ğam '̇̃ }\end{array}$ & $\#$ & $\begin{array}{l}\text { A noun of genus where the singular and plural share } \\
\text { the same basic form in meaning and pronunciation. } \\
\text { The singular form is distinguished by adding the } \\
\text { feminine } t \bar{a} \text { ' marbütah or the relative suffix - } \bar{l} \text {. E.g. هرب (عربي) (jهر) zahr (zahrah) 'flowers' ('a flower'), and } \\
\text { (arab ('arabī) 'Arabs' ('an Arab'). }\end{array}$ \\
\hline 32 & $\begin{array}{l}\text { Elative noun } \\
\text { اسم تفضيل } \\
\text { 'ism tafḍ̂l }\end{array}$ & (a) & 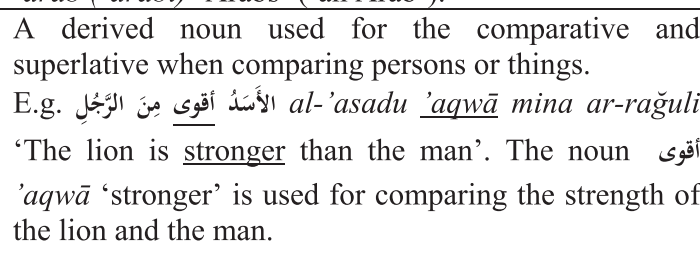 \\
\hline
\end{tabular}




\begin{tabular}{|c|c|c|c|}
\hline & Noun types & $\mathbf{T}$ & Meaning and Examples \\
\hline 33 & $\begin{array}{l}\text { Blend noun } \\
\text { 'ism manhật }\end{array}$ & $\%$ & 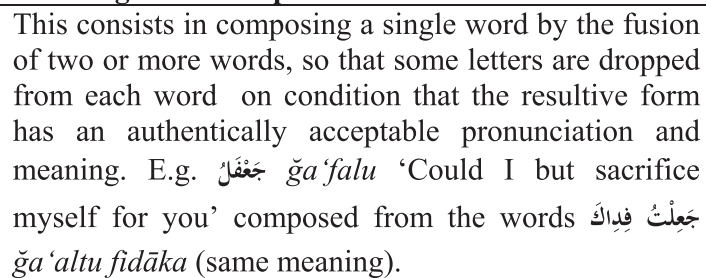 \\
\hline 34 & $\begin{array}{l}\text { Ideophonic interjection } \\
\text { صوت 'ism șawt }\end{array}$ & $!$ & $\begin{array}{l}\text { A noun improvised by human spontaneity and used } \\
\text { initially as a verbal noun to talk to animals and small } \\
\text { children, e.g. oا } \bar{a} h \text { "Oh", J } h \bar{a} l \text { used for horses. }\end{array}$ \\
\hline
\end{tabular}

gender words. The morphological feature of gender is represented at position 7 in the tag string.

Morphologically the masculine form shows the simplest and most basic shape (word structure), whereas feminine nouns usually have a suffix that marks their gender. On the other hand, semantically, nouns are arbitrarily classified into masculine or feminine, except where a noun refers to a human being or other creature, when it normally conforms to natural gender (Ryding 2005). Therefore, we can distinguish between two types of the morphological feature of gender that nouns can indicate: semantic gender and morphological gender. Semantic gender occurs where nouns indicate the natural gender of a human being or animal (male or female) or figurative gender for things that do not have natural gender. Morphological gender is defined by the noun being in its simplest form or by containing a feminine suffix attached to it. Discussion of the detailed classification of the morphological feature of gender into morphological gender and semantic gender is beyond the scope of this paper; we hope to present this in a later paper.

\subsection{The morphological feature of unaugmented and augmented}

Arabic verbs have roots consisting of three or four letters. From these roots many verbs can be derived by following certain patterns. There are many patterns for Arabic verbs. The standard way of determining the pattern of a verb is to refer to an Arabic lexicon or dictionary. Nonetheless, Arabic linguists have constructed general rules to extract these patterns. Verbs have two basic patterns consisting of three or four letters

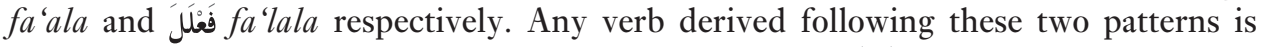

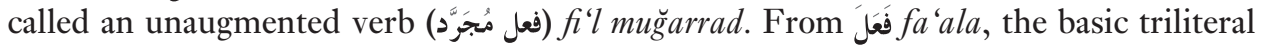
pattern, 10 more patterns can be derived, and from فُ فَعَ falala, the basic quadriliteral pattern, 3 more patterns can be derived. These new patterns are derived by adding one, two or three letters to the basic patterns or by duplicating the second letter $\varepsilon$ 'ayn of the basic pattern. The group of letters that are added to the basic patterns to produce

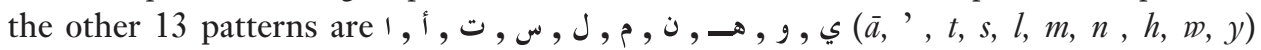




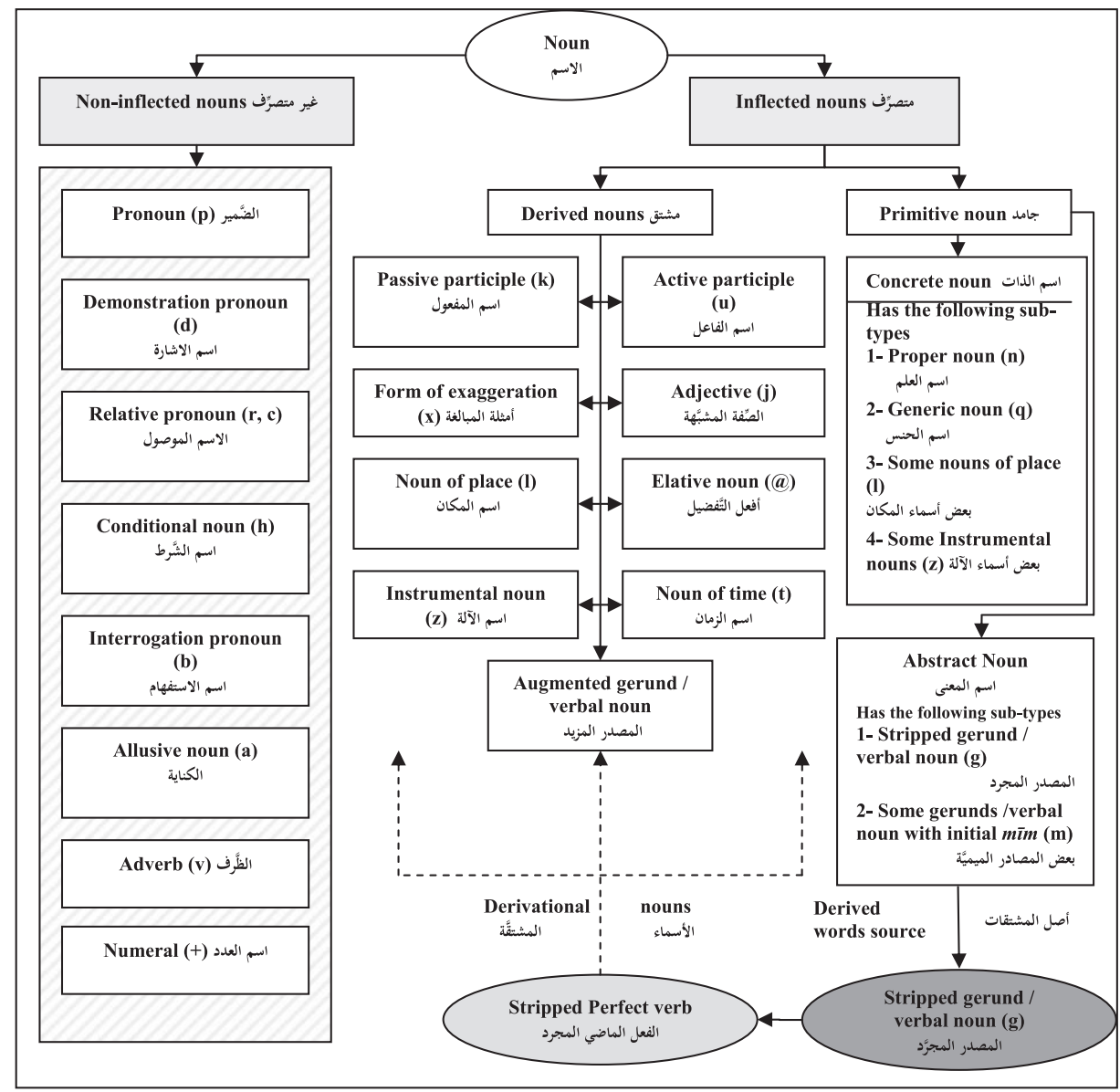

Figure 16. The classification attributes of noun part-of-speech subcategories with letter at position 2 .

that combine with the word سألتمونيها sa'altumūnīhā 'you (second person, plural) asked me it (feminine, singular)' (Dahdah 1987; Dahdah 1993; Al-Ghalayyni 2005).

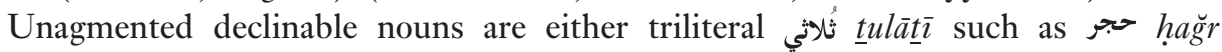
'stone', quadriliteral رُباعي rubā'

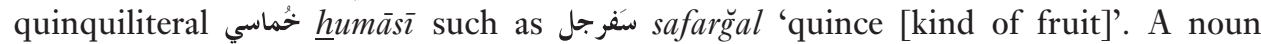
which consists of more than five letters is an augmented noun. A noun can be augmented by one letter مزيد بحرف hazì̃ bị̂n 'horse' (augmented by $\bar{a}$ ا) aindīl 'light' (augmented by

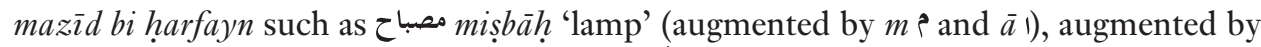
three letters مزيد بثلاثة أحرف mazīd bi talātata 'ahruf such as انطلاق 'intilāq 'starting'

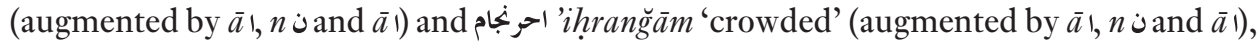




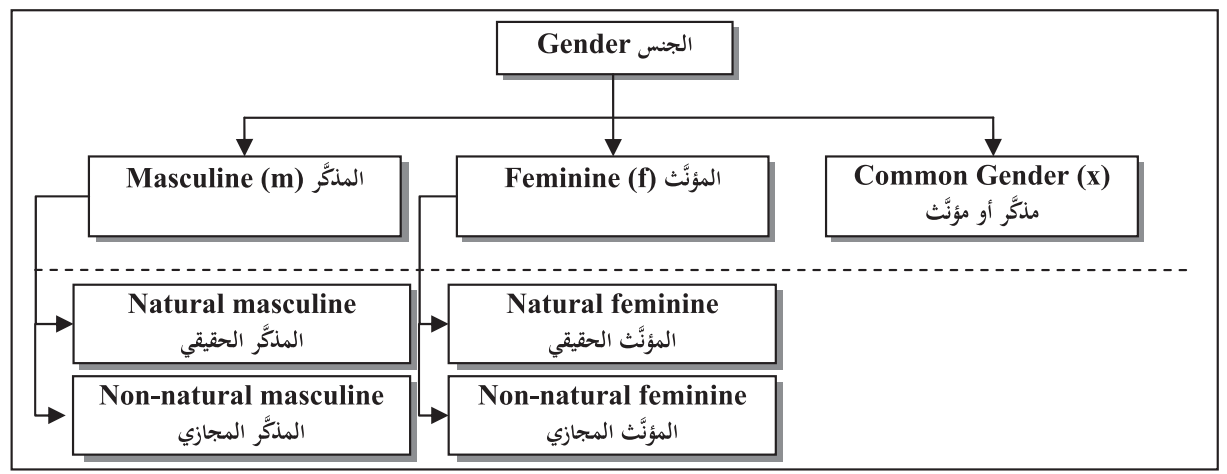

Figure 17. Arabic classification of nouns according to gender, with letter at position 7.

Table 5. Examples of gender category attributes for nouns, verbs, adjectives and pronouns.

\begin{tabular}{|c|c|c|c|c|c|c|}
\hline \multirow[t]{2}{*}{ \# } & \multirow{2}{*}{$\begin{array}{l}\begin{array}{l}\text { Subcategories of } \\
\text { gender }\end{array} \\
\end{array}$} & \multirow[t]{2}{*}{$\mathbf{T}$} & \multicolumn{4}{|c|}{ Examples } \\
\hline & & & Noun & Verb & Adjective & Pronoun \\
\hline 1 & $\begin{array}{l}\text { Masculine } \\
\text { مذكر } \\
\text { mudakkar }\end{array}$ & m & $\begin{array}{l}\text { كتاب } \\
\text { kitāa } \\
\text { book }\end{array}$ & $\begin{array}{l}\text { يكتبون yaktubūn } \\
\text { they are writing } \\
\text { (pl. / masc.) }\end{array}$ & $\begin{array}{l}\text { كاتب kātib writer } \\
\text { (sing. / masc.) }\end{array}$ & $\begin{array}{ll}\text { ه } & h u w a \\
\text { he } & \end{array}$ \\
\hline 2 & $\begin{array}{l}\text { Feminine } \\
\text { مؤن } \\
\text { mu'annat }\end{array}$ & f & $\begin{array}{l}\text { مكتبة } \\
\text { maktaba }{ }^{h} \\
\text { library }\end{array}$ & $\begin{array}{l}\text { تكتبين taktubin } \\
\text { you are writing } \\
\text { (sing. / fem.) }\end{array}$ & $\begin{array}{l}\text { كاتبة kātiba }{ }^{h} \text { writer } \\
\text { (sing. / fem.) }\end{array}$ & $\begin{array}{ll} & \text { hiya } \\
\text { she } & \end{array}$ \\
\hline 3 & $\begin{array}{l}\text { Common gender } \\
\text { مذكر أو مؤنث } \\
\text { mudakkar 'aw } \\
\text { mu'annat }\end{array}$ & $\mathbf{x}$ & $\begin{array}{l}\text { ملح } \\
\text { milh } \\
\text { salt }\end{array}$ & $\begin{array}{l}\text { نكتب naktubu } \\
\text { we are writing } \\
\text { (pl. / masc. or } \\
\text { fem.) }\end{array}$ & 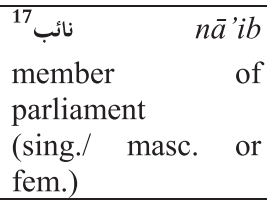 & $\begin{array}{l}\text { هo huma } \\
\text { they } \\
\text { (dual) }\end{array}$ \\
\hline
\end{tabular}

or augmented by four letters مزيد بأربعة أحرف mazīd bi 'arba'a 'a 'ahruf such as استغفار 'isti $\bar{g} f \bar{a} r$ 'asking for forgiveness' (augmented by $\bar{a}$ I, $s, t=$, and $\bar{a}$ ا).

Table 6 shows examples of the 5 Unaugmented and Augmented category attributes. Figure 18 shows the 5 attributes of the Unaugmented and Augmented category, represented at position 19 in the tag string.

\section{Evaluation}

Two ways to validate the SALMA Tag Set of Arabic are: one, to propose it as a standard to the Arabic language computing community and have the standard adopted by others; two, to see how readily it can be applied to a sample of Arabic text, for example by mapping from an existing tagged corpus to the SALMA tag set. 
Table 6. Examples of Unaugmented and Augmented category attributes.

\begin{tabular}{|c|c|c|c|c|}
\hline \multirow{2}{*}{$\begin{array}{l}\text { Unaugmented and } \\
\text { Augmented }\end{array}$} & \multirow[t]{2}{*}{$\mathbf{T}$} & Example & \multirow[b]{2}{*}{ Quadriliteral verbs } & \multirow[b]{2}{*}{ Nouns } \\
\hline & & Triliteral verbs & & \\
\hline $\begin{array}{l}\text { Unaugmented } \\
\text { المُجرَّد } \\
\text { al-muğarrad }\end{array}$ & $\mathbf{s}$ & $\begin{array}{l}\text { فَfataha } \\
\text { 'he opened'. }\end{array}$ & dahrağa 'rolled'. & 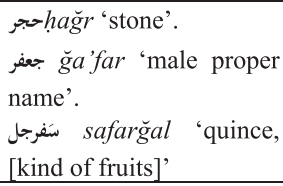 \\
\hline $\begin{array}{l}\text { Augmented by one letter } \\
\text { مَزْيد بِحَرف mazid bi harf } \\
\text { mail }\end{array}$ & a & $\begin{array}{l}\text { يَ yaftahu 'he is } \\
\text { opening'. } \\
\text { The letter } y \bar{a} \text { ' ي is } \\
\text { added to the } \\
\text { beginning of the verb } \\
\text { stem fataha }\end{array}$ & $\begin{array}{l}\text { دُ يُدَرُجَ yudahriğu 'he is } \\
\text { rolling'. } \\
\text { The letter } y \bar{a} \text { ' is } \\
\text { added to the beginning } \\
\text { of the verb stem } \\
\text { dahrağa. }\end{array}$ & $\begin{array}{l}\text { حصiṣān 'horse'. } \\
\text { قنديل qindīl 'light'. }\end{array}$ \\
\hline $\begin{array}{l}\text { Augmented by two letters } \\
\text { مَزيْد بِحَفَيْنْ } \\
\text { mazìd bi harfayn }\end{array}$ & $\mathbf{b}$ & 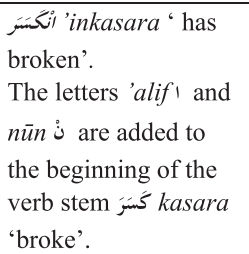 & 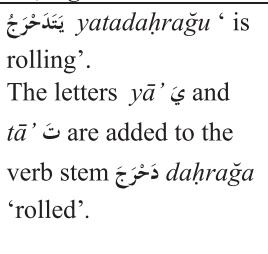 & مصباح miṣbāhh 'lamp'. \\
\hline 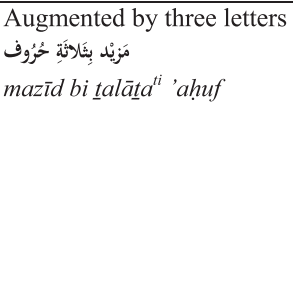 & $\mathbf{t}$ & 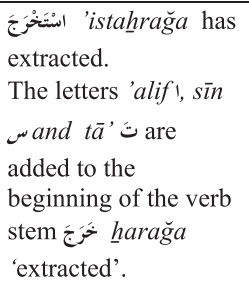 & & $\begin{array}{l}\text { احطاق 'ințilāq 'starting' } \\
\text { احرنجام 'ihranğām } \\
\text { 'crowded' }\end{array}$ \\
\hline $\begin{array}{l}\text { Augmented by four letters } \\
\text { مزيد بأربعة أحوف } \\
m a z i d d ~ b i ~ ' a r b a ' a^{t i} \text { 'ahruf }\end{array}$ & $\mathbf{q}$ & - & & $\begin{array}{l}\text { استغفار 'istiğfār 'asking for } \\
\text { forgiveness' }\end{array}$ \\
\hline
\end{tabular}

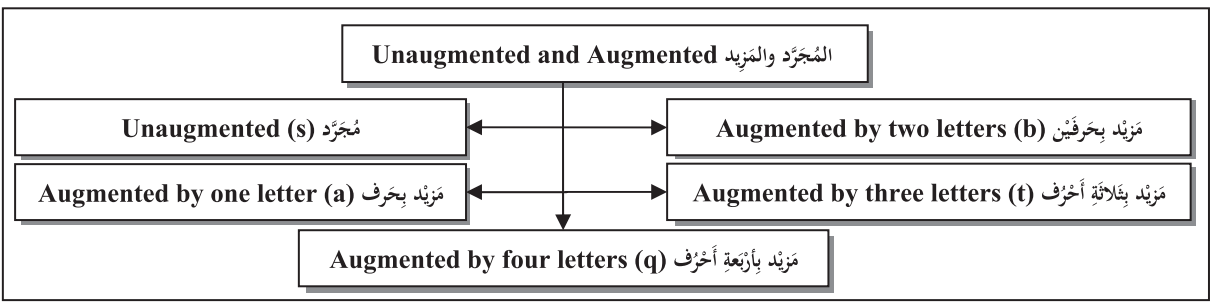

Figure 18. The Unaugmented and Augmented category attributes, with letter at position 19.

The SALMA - Tag Set has been used in the SALMA - Tagger (Sawalha Atwell Leeds Morphological Analysis - Tagger). It is used as the standard for specifying the word's morphemes and for encoding the morphological features of each morpheme (Sawalha \& Atwell 2009b; Sawalha \& Atwell 2009a). The SALMA - Tag Set has been published online (http://www.comp.leeds.ac.uk/sawalha/tagset.html) and has been 
adopted as a standard by other Arabic language computing researchers. For instance, part of the tag set is also used in the Arabic morphological analyzer and part-of-speech tagger Qutuf (Altabbaa, Al-Zaraee \& Shukairy 2010). Qutuf uses the main partof-speech, the subcategories of nouns, the subcategories of verbs named as verb aspects, the subcategories of particles and the morphological features of gender, number, person, case or mood, definiteness, voice, transitivity, and part of the declension and conjugation category named as perfectness. Qutuf does not use the SALMA - Tag format. Rather it uses a tag consisting of slots for each feature separated by a comma. Another re-use of the SALMA - Tag Set has been reported as a standard for evaluating Arabic morphological analyzers, and for building a Gold Standard for evaluating Arabic morphological analyzers and part-of-speech taggers (Hamada 2010).

Our second method for evaluating the SALMA - Tag Set is to apply it to a sample of Arabic text, by mapping from an existing broad tag set to the more fine-grained SALMA - Tag Set. We used the Quranic Arabic Corpus morphological annotation of a sample text, chapter 29, consisting of about 1,000 words. We developed an automated mapping algorithm to map the Quranic Arabic Corpus morphological tags to our SALMA - Tags. After that, the automatically mapped morphological features tags were manually verified and corrected to provide a new fine-grain Gold Standard for evaluating Arabic morphological analyzers and part-of-speech taggers.

The mapping from the Quranic Arabic Corpus morphological tag set to the SALMA - Tag Set was done by the following five-step procedure. First, mapping classical to modern character-set: the Quranic Arabic Corpus uses the classical Othmani script of the Qur'an (77,430 words) which was mapped to the Modern Standard Arabic (MSA) script (77,797 words). This was achieved by applying one-toone mapping except for some cases where one word in Othmani script is mapped to

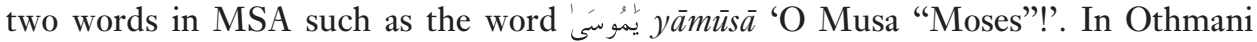

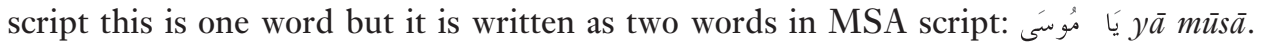
Second, splitting whole-word tags into morpheme-tags: the morphological tag in the Quranic Arabic Corpus is a whole-word tag, composed by combining the prefix with the stem and suffix morphological tags, separated by $(+)$ signs. The words and their morphological tags were automatically divided into morphemes and morphemes tags. Third, mapping of feature-labels: the mnemonics of the Quranic Arabic Corpus tags were mapped to their equivalent in the SALMA - Tag Set. Then, SALMA - Tag Set templates were applied to specify the applicable and non-applicable morphological features of the analyzed morpheme. Fourth, adjustments to morpheme tokenization: due the differences between the underlying word tokenization model used in the Quranic Arabic Corpus and the one required for the SALMA - Tag Set, we replaced the mapped tags of the prefixes and suffixes with SALMA tags by matching them to the clitics and affixes lists used by the SALMA - Tagger (Sawalha \& Atwell 2009a; Sawalha \& Atwell 2010). Fifth, extrapolation of missing fine-grain features: for these morphological features which are not included in the Quranic Arabic Corpus tag set, automatic 'feature-prediction' procedures applied linguistic knowledge extracted from traditional Arabic grammar textbooks, encoded as a computational 


\begin{tabular}{|c|c|c|c|c|}
\hline & QAC morpheme tag & SALMA tags: steps 1-4 & SALMA tags: step 5 & SALMA tags: corrected \\
\hline+1 & POS:INL & p--?------????---?----- & p--?-----s-s---------- & p--b-----s-s---------- \\
\hline أَ & A:INTG+ & p--i-----s------------- & p--i-----s------------- & p--i-----s------------- \\
\hline حَسِبَ & POS:V PERF 3MS & v-p---mst--?-?-??????- & v-p---msts-f-ambhvsta- & v-p---msts-f-amohvsta- \\
\hline ال & Al+ & 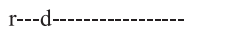 & 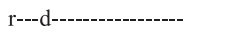 & r---d---------------- \\
\hline 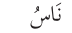 & POS:N MP NOM & n?----mp-?n??---????-? & n?----mp-vndd---ndst-s & n\#----mj-vndd---hdst-s \\
\hline أَنْ & POS:SUB & p--g-------?-------- & p--g-----S-S---------- & p--g-----S-S--------- \\
\hline ين & NULL & r---a----------------- & r---a----------------- & r---a-----------------' \\
\hline تَرَكُكُ & $\begin{array}{l}\text { POS:V IMPF PASS 3MP } \\
\text { MOOD:SUBJ }\end{array}$ & v-c---mptda?-p???????- & v-c---mptdao-pmbhvtta- & v-c---mptdao-pmohvtta- \\
\hline $\lg$ & PRON:3MP & r---r-mptsnw---------- & r---r-mptsnw---------- & r---r-mpts-s---------- \\
\hline أَنْْ & POS:SUB & p--g--------?----------- & p--g-----S-S----------- & p--g-----S-S----------- \\
\hline ي & NULL & r---a------------------ & r---a------------------ & r---a---------------- \\
\hline قُولُ & POS:V IMPF 3MP MOOD:SUBJ & v-c---mptda?-????????- & v-c---mptdao-amohvtto- & v-c---mptdao-amohvtto- \\
\hline $\lg$ & PRON:3MP & r---r-mptsnw---------- & r---r-mptsnw---------- & r---r-mpts-s---------- \\
\hline آَمَنَ & POS:V PERF (IV) 1MP & v-p---mpf--?-?-??????- & v-p---mpfs-s-amohvttc- & v-p---mpfs-s-amohvttc- \\
\hline نَا & PRON:1MP & r---r-xpfs??---------- & r---r-xpfs??---------- & r---r-xpfs-s---------- \\
\hline وَ & wat & p--c------------------- & p--c------------------- & p--c------s-f-------- - \\
\hline هُمْ & POS:PRON 3MP & np----mpt--??---?----- & np----mpts-si---hn---? & np----mpts-si---h n---- \\
\hline لأ & POS:NEG & p--n-------?--------- & p--n-----s-s---------- & p--n-----s-s---------- \\
\hline ين & NULL & r---a---------------- & r---a----------------- & r---a---------------- \\
\hline فْتَنُ & POS:V IMPF PASS 3MP & v-c---mpt-??-p???????- & v-c---mptdnn-pmohvtta- & v-c---mptdnn-pmohvtta- \\
\hline 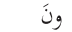 & PRON:3MP & r---r-mp?snn---------- & r---r-mp?snn---------- & r---r-mpts-f---------- \\
\hline
\end{tabular}

Figure 19. A sample of the Quranic Arabic Corpus tags and their mapped SALMA tags after applying the mapping procedure steps $1-4$, step 5 and manually correcting the tags.

rule-based system, to automatically predict the values of the missing morphological features of the word. Finally, the mapped SALMA tags were manually proofread and corrected by an Arabic language expert. The result is a sample Gold Standard annotated corpus for evaluating morphological analyzers and part-of-speech taggers for Arabic text.

Figure 19 shows examples of mapping from the Quranic Arabic Corpus tags to SALMA - tags, at various stages of processing: results after applying steps 1 to 4, the results after applying step 5, and the results after manually proofreading and correcting the tags. Figure 20 shows the percentage of cases mapped correctly for each morphological feature after applying steps 1 to 4, step 5, and the percentage of cases corrected manually for each category. Individual features required varying amounts of manual correction, ranging from Punctuation and Verb Root features which were predicted with $0 \%$ error rate, to $37.26 \%$ error rate in predicting Case and Mood Marks. Overall, 53.5\% of whole tags needed some correction in the final proofreading 


\begin{tabular}{|l|l|c|c|c|}
\hline \multicolumn{2}{|l|}{ Category } & $\begin{array}{c}\text { Mapping } \\
\text { steps 1-4 }\end{array}$ & $\begin{array}{c}\text { mapping } \\
\text { step 5 }\end{array}$ & $\begin{array}{c}\text { Manual } \\
\text { correction }\end{array}$ \\
\hline 1 & Main Part-of-Speech & $99.17 \%$ & $100.00 \%$ & $2.91 \%$ \\
\hline 2 & Part-of-Speech: Noun & $50.60 \%$ & $83.05 \%$ & $20.04 \%$ \\
\hline 3 & Part-of-Speech: Verb & $100.00 \%$ & $100.00 \%$ & $0.07 \%$ \\
\hline 4 & Part-of-Speech: Particle & $93.93 \%$ & $97.79 \%$ & $5.44 \%$ \\
\hline 5 & Part-of-Speech: Other (Residual) & $100.00 \%$ & $100.00 \%$ & $7.38 \%$ \\
\hline 6 & Punctuation marks & $100.00 \%$ & $100.00 \%$ & $0.00 \%$ \\
\hline 7 & Gender & $89.13 \%$ & $92.83 \%$ & $15.87 \%$ \\
\hline 8 & Number & $77.57 \%$ & $82.24 \%$ & $30.25 \%$ \\
\hline 9 & Person & $84.58 \%$ & $100.00 \%$ & $8.27 \%$ \\
\hline 10 & Inflectional Morphology & $89.29 \%$ & $100.00 \%$ & $16.69 \%$ \\
\hline 11 & Case or Mood & $68.61 \%$ & $85.24 \%$ & $29.36 \%$ \\
\hline 12 & Case and Mood Marks & $17.28 \%$ & $86.46 \%$ & $37.26 \%$ \\
\hline 13 & Definiteness & $14.10 \%$ & $100.00 \%$ & $5.22 \%$ \\
\hline 14 & Voice & $7.17 \%$ & $100.00 \%$ & $2.01 \%$ \\
\hline 15 & Emphasized and Non-emphasized & $12.31 \%$ & $100.00 \%$ & $0.07 \%$ \\
\hline 16 & Transitivity & $0.00 \%$ & $100.00 \%$ & $0.45 \%$ \\
\hline 17 & Rational & $0.00 \%$ & $100.00 \%$ & $8.20 \%$ \\
\hline 18 & Declension and Conjugation & $4.93 \%$ & $100.00 \%$ & $14.31 \%$ \\
\hline 19 & Unaugmented and Augmented & $0.00 \%$ & $100.00 \%$ & $6.93 \%$ \\
\hline 20 & Number of Root Letters & $0.00 \%$ & $100.00 \%$ & $0.37 \%$ \\
\hline 21 & Verb Root & $0.00 \%$ & $100.00 \%$ & $0.00 \%$ \\
\hline 22 & Noun Finals & $0.00 \%$ & $91.70 \%$ & $9.69 \%$ \\
\hline & & & & \\
\hline
\end{tabular}

Figure 20. The percentage of each morphological feature mapped after applying steps 1 to 4 , step 5, and the percentage of errors corrected in final proofreading for each category.

stage; however, many of these corrections were very minor such as replacing '?' (unknown) with '-' (not applicable). The use of 22 morphological feature categories for each morpheme is bound to increase the potential for making annotation mistakes; however, this result demonstrates that the SALMA - Tag Set can feasibly be used to annotate Arabic text corpora with rich morphological information, appropriate to the rich morphology of Arabic.

\section{Conclusions}

A range of Arabic Part-of-Speech taggers exist, each with a different tag set; we have illustrated and compared some of these, and this suggests the need for a common standard to simplify and promote comparisons and sharing of resources. We review generic design criteria for corpus tag sets, and see that some of these principles have been applied in existing tag sets; but there is still room for improvement, in the design of a standard tag set for Arabic Part-of-Speech taggers and tagged corpora. The SALMA - Tag Set captures long-established traditional morphological features of Arabic, in a compact yet transparent notation. A tag consists of 22 characters; each position represents a feature and the letter at that location represents a value or attribute of the morphological feature; the dash '-' represents 
a feature not relevant to a given word. The SALMA - Tag Set is not tied to a specific tagging algorithm or theory, and other tag sets could be mapped onto this standard, to simplify and promote comparisons between and reuse of Arabic taggers and tagged corpora.

The SALMA - Tag Set has been validated in two ways. First, it was validated by proposing it as a standard to Arabic language computing community, and has been adopted in Arabic language processing systems. The SALMA - Tag Set has been used in the SALMA - Tagger to encode the morphological features of each morpheme (Sawalha \& Atwell 2009a; Sawalha \& Atwell 2010). Parts of The SALMA - Tag Set were also used in the Arabic morphological analyzer and part-of-speech tagger Qutuf (Altabbaa et al. 2010). Moreover, the SALMA - Tag Set has been reported as a standard for evaluating morphological analyzers for Arabic text and for building a gold standard for evaluating morphological analyzers and part-of-speech taggers for Arabic text (Hamada 2010).

Second, we presented an empirical approach to evaluating the SALMA - Tag Set of Arabic, showing that it can be applied to an Arabic text corpus, by mapping from an existing tag set to the SALMA - Tag Set. The morphological tags of a 1,000-word test text, chapter 29 of the Quranic Arabic Corpus, were automatically mapped to SALMA tags. Then, the mapped tags were proofread and corrected. The result of mapping and correction of the SALMA - tagging of this corpus is a new Gold Standard for evaluating Arabic morphological analyzers and part-of-speech taggers with a detailed fine-grain description of the morphological features of each morpheme, encoded using SALMA tags.

We invite other Arabic language computing researchers to take up the SALMA - Tag Set and Gold Standard tagged corpus, to promote comparability and interoperability of Arabic morphological analysers and Part-of-Speech taggers.

\section{Appendix - A The SALMA Tag Set for Arabic text}

Table A.1. SALMA Tag Set categories.

\begin{tabular}{|c|c|c|c|}
\hline Position & \multicolumn{3}{|c|}{ Morphological Features Categories } \\
\hline 1 & Main Part-of-Speech & أَقسام الكلام الرئيسيَّة & 'aqsām al-kalām ar-r'issiyya ${ }^{t}$ \\
\hline 2 & Part-of-Speech: Noun & أقسام الكلام الفرعيَّة (الاسم) & 'aqsām al-kalām al-far 'iyyat (al-'ism) \\
\hline 3 & Part-of-Speech: Verb & أقسام الكلام الفرعيَّة (الفعل) & 'aqsām al-kalām al-far 'iyya ${ }^{t}($ al-fi 'l) \\
\hline 4 & Part-of-Speech: Particle & أقسام الكلام الفرعيَّة (الحرف) & 'aqsām al-kalām al-far 'iyya' (al-harf) \\
\hline 5 & $\begin{array}{l}\text { Part-of-Speech: Other } \\
\text { (Residual) }\end{array}$ & أقسام الكلام الفرعيَّة (أخرى) & 'aqsām al-kalām al-far'iyya ('uhrrā) \\
\hline 6 & Punctuation marks & 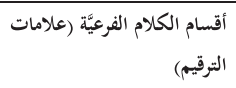 & $\begin{array}{l}\begin{array}{l}\text { 'aqsām } \\
\text { tarqüm) }\end{array} \\
\text { al-kalām al-far'iyyat }{ }^{t} \text { ('alāmāt at- }\end{array}$ \\
\hline 7 & Gender & 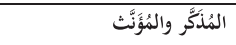 & al-mudakkar wa al-mu'annat \\
\hline 8 & Number & 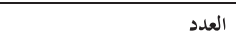 & al-'adad \\
\hline 9 & Person & 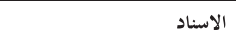 & al-'isnād \\
\hline
\end{tabular}




\begin{tabular}{|c|c|c|c|}
\hline Position & Morphological Featur & Categories & \\
\hline 10 & Inflectional Morphology & الصَّرف & as-șarf \\
\hline 11 & Case or Mood & الحالة الإعرابية للاسم أو الفعل & 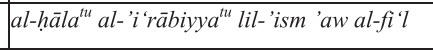 \\
\hline 12 & Case and Mood Marks & علامة الإعراب أو البناء & 'alāmāt al-'i 'räb wa al-binā' \\
\hline 13 & Definiteness & 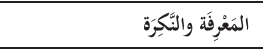 & al-ma 'rifa ${ }^{t i}$ wa an-nakira ${ }^{t i}$ \\
\hline 14 & Voice & المَبْني لِلمَعَلُوم و المَبْني بلِلمَجْهُول & al-mabnì lil-ma '̄ūm wa al-mabnī lil-mağhūl \\
\hline 15 & $\begin{array}{l}\text { Emphasized and Non- } \\
\text { emphasized }\end{array}$ & المُؤكُد وغيرُ المُؤَكُد & al-mu'akkad wa ḡayir al-mu'akkad \\
\hline 16 & Transitivity & الملازم والمتعدي & Al-lāzim wa al-muta'adi \\
\hline 17 & Rational & العاقل وغير العاقل & al-'āqil wa ḡayir al-'āqil \\
\hline 18 & $\begin{array}{l}\text { Declension and } \\
\text { Conjugation }\end{array}$ & التَّصريف & at-tașrīf \\
\hline 19 & $\begin{array}{l}\text { Unaugmented and } \\
\text { Augmented }\end{array}$ & المجرَّد والمزيد & al-muğarrad wa al-mazìd \\
\hline 20 & Number of Root Letters & عَدَد أخحرُف الجَذْر & 'adad 'ahruf al-ğad $r$ \\
\hline 21 & Verb Root & 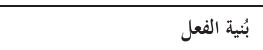 & bunya ${ }^{t u}$ al-fi ${ }^{`} l$ \\
\hline 22 & Noun Finals & أقسام الأسم تبعاً للفظ آخره & 'aqsām al-'ismi tib 'an li-lafẓi 'āhirhi \\
\hline
\end{tabular}

Table A.2. Main part-of-speech category attributes and tags at position 1.

\begin{tabular}{|c|c|c|c|c|c|}
\hline \multirow{2}{*}{$\begin{array}{l}\text { Position } \\
1\end{array}$} & \multicolumn{4}{|l|}{ Feature Name } & \multirow[t]{2}{*}{ Tag } \\
\hline & \multicolumn{4}{|c|}{ Main Part-of-Speech أقسام الكلام الرئيسيَّة 'aqsām al-kalām ar-r'īsiyya ${ }^{t}$} & \\
\hline & Noun & اسم & 'ism & kitāa 'book' & $\mathbf{n}$ \\
\hline & Verb & فعل & $f i l$ & katab 'wrote' & $\mathbf{v}$ \\
\hline & Particle & حرف & harf & عَلَى 'alā' 'on' & $\mathbf{p}$ \\
\hline & Other (Residual) & أخرى & 'uhrāa & كاتِبة $k a ̄ t i b a$ tun 'writer. FEM & $\mathbf{r}$ \\
\hline & Punctuation & علامة ترقيم & 'alāmat tarqìm & 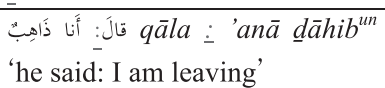 & $\mathbf{u}$ \\
\hline
\end{tabular}

Table A.3. Part-of-Speech subcategories of Noun attributes and their tags at position 2.

\begin{tabular}{|c|c|c|c|c|c|}
\hline \multirow{2}{*}{$\begin{array}{c}\text { Position } \\
2\end{array}$} & \multicolumn{4}{|l|}{ Feature Name } & \multirow[t]{2}{*}{ Tag } \\
\hline & \multicolumn{4}{|c|}{ Part-of-Speech: Noun (أقسام الكلام الفرعيَّة (الاسم) 'aqsām al-kalām al-far 'iyya ' (al- 'ism) } & \\
\hline & $\begin{array}{l}\text { Gerund / Verbal } \\
\text { noun }\end{array}$ & المصدر & al-mașdar & لَّبَ darb 'hitting' & 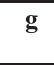 \\
\hline & $\begin{array}{l}\text { Gerund/ verbal noun } \\
\text { with initial } \mathrm{mi} m\end{array}$ & المصيمي & al-mașdar al-mīmī & مَوعِد maw'id 'date' & $\mathbf{m}$ \\
\hline & Gerund of instance & مصدر المرَّة & mașdar al-marra ${ }^{h}$ & 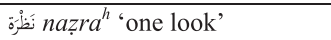 & $\mathbf{0}$ \\
\hline & Gerund of state & مصدر الهيئة/ مصدر & $\begin{array}{l}\text { mașdar al-hay'a }{ }^{h} / \\
\text { mașdar al-naw' }\end{array}$ & 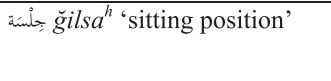 & $\mathbf{s}$ \\
\hline
\end{tabular}




\begin{tabular}{|c|c|c|c|c|c|}
\hline \multirow{2}{*}{\begin{tabular}{|c|} 
Position \\
2 \\
\end{tabular}} & \multicolumn{4}{|l|}{ Feature Name } & \multirow{3}{*}{$\begin{array}{r}\text { Tag } \\
\mathrm{e}\end{array}$} \\
\hline & \multicolumn{4}{|c|}{ Part-of-Speech: Noun (الاسم) 'aqsām al-kalām al-far 'iyyat (al-'ism) } & \\
\hline & Gerund of emphasis & مصدر التوكيد & mașdar al-tawkìd & 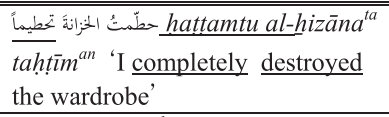 & \\
\hline & Gerund of profession & الصناعي & al-mașdar al-șinā' & مُروسيَّة furūsiyya ${ }^{h}$ 'Horsemanship' & $\bar{i}$ \\
\hline & Pronoun & 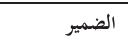 & al-damīr & هوuwa 'He' & $\mathbf{p}$ \\
\hline & $\begin{array}{l}\text { Demonstrative } \\
\text { pronoun }\end{array}$ & اسم الإشارة & 'ism al-'̌š̄ra ${ }^{h}$ & ه $h \bar{a} \underline{d} \bar{a}$ 'This' & d \\
\hline & $\begin{array}{l}\text { Specific relative } \\
\text { pronoun }\end{array}$ & الخماص الموصول & $\begin{array}{l}\text { 'ism al-mawṣūl al- } \\
\underline{h} \bar{a} s \underline{\text { s }}\end{array}$ & الذي al-ladِ & $\mathbf{r}$ \\
\hline & $\begin{array}{l}\text { Non-specific relative } \\
\text { pronoun }\end{array}$ & المثم الموصول & $\begin{array}{l}\text { 'ism al-mawṣūl al- } \\
\text { muštarak }\end{array}$ & مَman 'Who' & c \\
\hline & $\begin{array}{l}\text { Interrogative } \\
\text { pronoun }\end{array}$ & 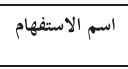 & 'ism al-'istfhām & 'man 'Who?' & b \\
\hline & Conditional noun & | اسم الشرط & 'ism al-šart & أينما aynamā 'Where ever' & $\mathbf{h}$ \\
\hline & Allusive noun & الكناية & al-kināya $^{h}$ & كذا kada 'As well as' & $\mathbf{a}$ \\
\hline & Adverb & الظُّف & $a z$-zarf & يوم yawm 'Day' & $\mathbf{v}$ \\
\hline & Active participle & اسم الفاعل & 'ism al-fä 'il & ضlārib 'Hitter' & $\mathbf{u}$ \\
\hline & $\begin{array}{l}\text { Intensive Active } \\
\text { participle }\end{array}$ & مبالغة اسم & $\begin{array}{l}\text { mubālaḡa } a^{t} \text { 'ism al- } \\
\text { fā'il }\end{array}$ & $\tau^{2}$ gَarrah 'Surgeon' & $\mathbf{w}$ \\
\hline & Passive participle & اسم المفعول & 'ism al-mf'ūl & 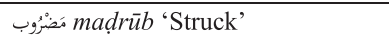 & $\mathbf{k}$ \\
\hline & Adjective & الصِّفة المشبَّهة & $\begin{array}{l}\text { aș-sifah al- } \\
\text { mušabbaha }\end{array}$ & طويل tawìl 'Tall' & $\mathbf{j}$ \\
\hline & Noun of place & اسم المكان & 'ism al-mkān & مَكْتَب maktab 'Office' & 1 \\
\hline & Noun of time & اسم زمان & 'ism zamōn & مَطِلِع $m a t l l i$ 'Start time' & $\mathbf{t}$ \\
\hline & Instrumental noun & اسم الآلة & 'ism al-'āla ${ }^{h}$ & من سنشار & $\mathbf{z}$ \\
\hline & Proper noun & 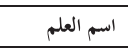 & 'ism al-'alam & فاطِمَة fātima ${ }^{h}$ 'Fatima' & $\mathbf{n}$ \\
\hline & Generic noun & اسم الجنس & 'ism al-ğins & istụān 'Horse' & $\mathbf{q}$ \\
\hline & Numeral & إسم العدد & 'ism al-'adad & 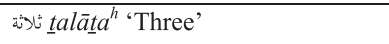 & + \\
\hline & Verb-like noun & اسم الفعل & 'ism al-fi'l & هيهات hayhāt Wishing & $\&$ \\
\hline & Five nouns & الخمسة & $\begin{array}{l}\text { al-'asmä'al- } \\
\underline{h a m s a}{ }^{h}\end{array}$ & أبنْ 'abather' & f \\
\hline & Relative noun & اسم منسوب & 'ism mansūb & 'ilmiyy ' عِلْمِيّ ${ }^{u n}$ Scientific & $*$ \\
\hline & Diminutive & اسم تصغير & 'ism tașḡìr & 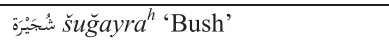 & $\mathbf{y}$ \\
\hline & $\begin{array}{l}\text { Form of } \\
\text { exaggeration }\end{array}$ & صيغة مبالغة & $s \bar{l} \bar{g} a^{t} a l-m u b \bar{a} l a \bar{g} a^{h}$ & جَبَّار & $\mathbf{x}$ \\
\hline & Collective noun & 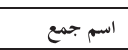 & 'ism ğam' & قوم qawm 'Folk' & $\$$ \\
\hline & Plural generic noun & جمعي جنس & 'ism ğins ğam '̄̄ & تفاح tuffāh!'Apple' & $\#$ \\
\hline & Elative noun & اسم تفضيل & 'ism tafḍ̄l & أفضل 'afḍal 'Better' & (a) \\
\hline & Blend noun & اسم منحوت & 'ism manḥūt & بملة basmala 'Bismallah' & $\%$ \\
\hline & $\begin{array}{l}\text { Ideophonic } \\
\text { interjection }\end{array}$ & اسم صوت & 'ism șawt & ot 'āh 'Ah' & $!$ \\
\hline
\end{tabular}


Table A.4. Part-of-Speech subcategory of verb attributes and their tags at position 3 .

\begin{tabular}{|c|c|c|c|c|c|}
\hline \multirow{2}{*}{$\begin{array}{l}\text { Position } \\
3\end{array}$} & \multicolumn{4}{|l|}{ Feature Name } & \multirow{3}{*}{$\begin{array}{c}\text { Tag } \\
p \text { p }\end{array}$} \\
\hline & \multicolumn{4}{|c|}{ Part-of-Speech: Verb أقسام الكلام الفرعيَّة (الفعل) 'aqsām al-kalām al-far 'iyya ${ }^{t}$ (al-fi'l) } & \\
\hline & Perfect verb & فعل ماض & fi'l mā $\bar{d}^{i n}$ & كَتَب kataba 'He wrote' & \\
\hline & Imperfect verb & فعل مضارع & fi'l muḍāri' & يَكْتُبُ yaktubu 'He is writing' & c \\
\hline & Imperative verb & فعل الأمر & fi'lal-'amr & اكتُبْ 'uktub 'write' & $\mathbf{i}$ \\
\hline
\end{tabular}

Table A.5. Part-of-speech subcategories of Particles attributes and their tags at position 4.

\begin{tabular}{|c|c|c|c|c|c|}
\hline \multirow{2}{*}{\begin{tabular}{|l|} 
Position \\
4 \\
\end{tabular}} & \multicolumn{4}{|l|}{ Feature Name } & \multirow{3}{*}{$\begin{array}{c}\text { Tag } \\
\mathbf{j}\end{array}$} \\
\hline & \multicolumn{4}{|c|}{ Part-of-Speech: Particle أَقسام الكلام الفرعيَة (الحروف) 'aqsām al-kalām al-far 'iyyat (al-harf) } & \\
\hline & Jussive-governing particle & 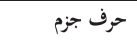 & harf $\breve{g} a z i m$ & lam 'No' & \\
\hline & Subjunctive-governing particle & حرف نصب & harf nașib & گ kay 'So that' & $\mathbf{0}$ \\
\hline & $\begin{array}{l}\text { Partially subjunctive- } \\
\text { governing particle }\end{array}$ & الفرف النصب & harf nașib far 'ī & حتى hattà 'Till' & $\mathbf{u}$ \\
\hline & Preposition & حرف جر & harf ğarr & إلى 'ilä 'To' & $\mathbf{p}$ \\
\hline & Annulling particle & حرف ناسخ & ḩarf nāsih & L $m \bar{a} ' \mathrm{No}^{\prime}$ & a \\
\hline & Conjunction & حرف عطف & harf 'ațif & , wa 'And' & c \\
\hline & Vocative particle & 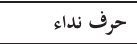 & harf nida'’ & ي $y \bar{a}$ 'Oh’ & $\mathbf{v}$ \\
\hline & Exceptive particle & حرف استثناء & harf 'stititnā' & إلاً 'illā 'Except' & $\mathbf{x}$ \\
\hline & Interrogative particle & حرف استفهام & harf' stifhām & do hal 'Is?' & $\mathbf{i}$ \\
\hline & Particle of futurity & حرف استقبال & harf 'stiqbāl & سوف sawfa 'Will' & $\mathbf{f}$ \\
\hline & Causative particle & حرف تعليل & harf ta 'lìl & كkay 'To' & $\mathbf{s}$ \\
\hline & Negative particle & حرف نفي & harf nafì & lam 'No' & $\mathbf{n}$ \\
\hline & Jurative particle & حرف قسم & harf qasam & y bi 'Swear' & $\mathbf{q}$ \\
\hline & Yes/No response particle & حوف الجواب & harf ğawāb & نعa' 'am 'Yes' & $\mathbf{w}$ \\
\hline & $\begin{array}{l}\text { Jussive-governing conditional } \\
\text { particle }\end{array}$ & حرف شرط جازم & harf šart ğāzim & إن 'in 'If' & $\mathbf{k}$ \\
\hline & Particle of incitement & حرف تحضيض & harf tahdịd & لَ hallā 'Would' & $\mathbf{m}$ \\
\hline & Gerund-equivalent particle & حوف مصدري & harf mașdarī & أن 'an 'To' & $\mathbf{g}$ \\
\hline & Particle of attention & حرف تنبيه & harf tanb $\vec{\imath}^{-h}$ & ألا 'alā 'Careful' & $\mathbf{t}$ \\
\hline & Emphatic particle & حرف توكيد & harf tawkīd & إنَّ 'inna 'Emphasis' & $\mathbf{z}$ \\
\hline & Explanatory particle & حرف تفسير & harf tafsir & أي 'ay 'i.e' & d \\
\hline & Particle of comparison & حرف تشبيه & harf tašb $\imath^{h}$ & كa'anna 'Similar' & 1 \\
\hline & Non-governing particles & حوف غير عامل & harf ḡayr 'āmil & $\begin{array}{l}\text { دَ qad 'Already or } \\
\text { perhaps' }\end{array}$ & b \\
\hline
\end{tabular}


Table A.6. Part-of-speech subcategories of Other (Residuals) attributes and their tags at position 5 .

\begin{tabular}{|c|c|c|c|c|c|}
\hline \multirow{2}{*}{$\begin{array}{l}\text { Position } \\
5 \\
\end{array}$} & \multicolumn{4}{|l|}{ Feature Name } & \multirow{3}{*}{$\begin{array}{c}\text { Tag } \\
p\end{array}$} \\
\hline & \multicolumn{4}{|c|}{ Part-of-Speech: Other أقسام الكلام الفرعيَة (أُخْرَى) 'aqsām al-kalām al-far'iyyat ('uhrāa) } & \\
\hline & Prefix & زليادة في أول & $\begin{array}{lr}\text { ziyāda } & \\
\text { 'awal }^{h} & f i \\
\text { kalima }^{h} & \text { al- } \\
\end{array}$ & $\begin{array}{l}\text { 'istaktabanī 'He } \\
\text { employed me as a writer' }\end{array}$ & \\
\hline & Suffix & زيادة في آخر & 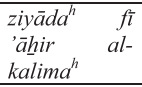 & 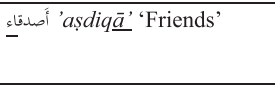 & $\mathbf{s}$ \\
\hline & Suffixed pronoun & 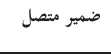 & $\begin{array}{l}\text { damīr } \\
\text { mutașil }\end{array}$ & كitaba ' كِنابُهُ & $\mathbf{r}$ \\
\hline & $t \bar{a}^{\prime}$ marbūta $a^{h}$ & تاء مربوطة & tā' marbūtata & كاتِِّ $k a ̄ t i b a^{\underline{t u n}}$ 'She-writer' & t \\
\hline & Relative $y \bar{a}^{\prime}$ & ياء النسبة & $y \bar{a}^{\prime}$ an-nisba ${ }^{h}$ & عرَرِي 'arabiyy 'Arabian' & $\mathbf{y}$ \\
\hline & tanwīn & تنوين & tanwīn & كِ kitāb $b^{u n}$ 'A book' & $\mathbf{k}$ \\
\hline & $t \bar{a}^{\prime}$ of femininization & تاء التأنيث & $t \bar{a}^{\prime} a l-t a^{\prime} n \bar{t} \underline{t}$ & كَتبَتْ katabat 'She wrote' & f \\
\hline & $n \bar{u} n$ of protection & 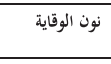 & $\begin{array}{ll}n \bar{u} n & a l- \\
\text { wiqāaya }^{h} & \end{array}$ & سَألكِيَ sa'alan̄i 'He asked me' & $\mathbf{n}$ \\
\hline & Emphatic $n \bar{u} n$ & نون التوكيد & $\begin{array}{l}\text { nūn } \\
\text { tawkīd }\end{array}$ & $\begin{array}{l}\text { يَضْرِ yadribanna 'They are } \\
\text { hitting' }\end{array}$ & $\mathbf{z}$ \\
\hline & Imperfect prefix & حرف مضارعة & $\begin{array}{l}\text { harf } \\
\text { muḍāara' } a^{h}\end{array}$ & لِ يَسَأَل yas 'alu 'He is asking' & a \\
\hline & Definite article & أداة تعريف & 'adāt ta'rīf & إ_ إكتاب & d \\
\hline & $\begin{array}{l}\text { Masculine } \\
\text { plural letters }\end{array}$ & حروف جمع المذكر السالم & $\begin{array}{l}\text { hurūf } \text { gam } \\
\text { al-mudakkar } \\
\text { as-sālim }\end{array}$ & $\begin{array}{l}\text { الكانتو } \quad a l-k a \bar{t} t i b \underline{u} n \\
\text { writers (MAS)' }\end{array}$ & m \\
\hline & $\begin{array}{l}\text { Feminine } \\
\text { plural letters }\end{array}$ & حوف جمع المؤث السالم & $\begin{array}{l}\text { hurūf } \breve{g a m}{ }^{\prime} \\
\text { al-mu'nnat } \\
\text { as-sālim }\end{array}$ & $\begin{array}{l}\text { الكاتبات } \quad a l-k a \bar{t} t i b \underline{a ̄ t} \quad \text { 'The } \\
\text { writers (FEM)' }\end{array}$ & 1 \\
\hline & Dual letters & حروف المثنى & $\begin{array}{l}\text { hurūf } \quad \text { al- } \\
\text { mutannāa }\end{array}$ & $\begin{array}{l}\text { الكاتبان al-kātibān 'The two } \\
\text { writers' }\end{array}$ & $\mathbf{u}$ \\
\hline & Imperative prefix & حروف الأمر & $\begin{array}{l}\text { ḩurūf al- } \\
\text { 'amr }\end{array}$ & 'Lيktub 'Write' & I \\
\hline & Number (digits) & رَقَم & raqam & $\begin{array}{ll}(+325461) & (-897,653) \\
(0.986) & \\
\end{array}$ & g \\
\hline & Currency & عُعْلَة & 'umla' & (..,2,927) & c \\
\hline & Date & تَارِيخ & tārīh & (27 أيلول 2011) (27/09/2011) & $\mathbf{e}$ \\
\hline & Non-Arabic word & كَلِمَة غَيْر غَرَبيَة & $\begin{array}{l}\text { kalima }{ }^{t} \bar{g} a y r \\
\text { 'arabiyya }^{h}\end{array}$ & $\begin{array}{l}\text { windows, photoshop, } \\
\text { games, download }\end{array}$ & $\mathbf{w}$ \\
\hline & $\begin{array}{l}\text { Borrowed (foreign) } \\
\text { word }\end{array}$ & كَلِمَة مُعَرَبَّة & $\begin{array}{l}\text { kalima }^{I} \\
m \text { m }^{\prime} \text { arraba }^{h}\end{array}$ & $\begin{array}{l}\text { kuzmūbülītān } \\
\text { 'cosmopolitan' }\end{array}$ & $\mathbf{x}$ \\
\hline
\end{tabular}

Table A.7. Part-of-speech subcategories of Punctuation Marks attributes and their tags at position 6 .

\begin{tabular}{|c|c|c|c|c|c|}
\hline \multirow{2}{*}{$\begin{array}{l}\text { Position } \\
6\end{array}$} & \multicolumn{4}{|l|}{ Feature Name } & \multirow{3}{*}{$\begin{array}{r}\text { Tag } \\
\mathrm{s}\end{array}$} \\
\hline & \multicolumn{4}{|c|}{$\begin{array}{c}\text { Punctuation Marks أقسام الكلام الفرعية (علامات الترقيم) 'aqsām al-kaläm al-far'iyya ' ('alāmāt at- } \\
\text { tarqīm) }\end{array}$} & \\
\hline & Full stop & نقطة & nuqta $^{h}$ & (.) & \\
\hline & Comma & فاصلة & fāșila & (c) & c \\
\hline & Colon & نقطتان & nuqtatān & (:) & $\mathbf{n}$ \\
\hline & Semi colon & فاصلة منقوطة & fäṣila ${ }^{h}$ manqūta ${ }^{h}$ & (५) & 1 \\
\hline & Parentheses & ق ق قوسان & qawsān & $(())$ & $\mathbf{p}$ \\
\hline & Square brackets & قوسان حاصرتان & qawsān hạșiratān & $([])$ & b \\
\hline & Quotation mark & علامة اقتباس & 'alāma 'iqtibās & $(" n)$ & $\mathrm{t}$ \\
\hline & Dash & شرطة معترضة & $\check{s ̌ a r t ̦ a}^{h} m u^{\prime}$ tariḍa ${ }^{h}$ & $(-)$ & d \\
\hline & Question mark & علامة استفهام & 'alāma ${ }^{\text {tu }}$ 'istifhām & 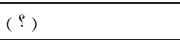 & $\mathbf{q}$ \\
\hline & Exclamation mark & علامة تعجب & 'alāma tu ta'ăğğub & $(!)$ & e \\
\hline & Ellipsis mark & علامة حذف & 'alāma $a^{t u}$ hadf & $(\cdots)$ & i \\
\hline & Continuation mark & علامة التًابعية & 'aläma ${ }^{t u}$ at-tabi' yya ${ }^{h}$ & $(=)$ & f \\
\hline
\end{tabular}


Table A.8. Morphological feature of Gender attributes and their tags at position 7.

\begin{tabular}{|c|c|c|c|c|c|}
\hline Position & \multirow{2}{*}{\multicolumn{4}{|c|}{$\begin{array}{l}\text { Feature Name } \\
\qquad \text { Morphological Gender المُذَكَّر والمُؤَنَثْ al-mudakkar wa al-mu'annat } \\
\end{array}$}} & \multirow{3}{*}{$\begin{array}{r}\text { Tag } \\
\mathrm{m}\end{array}$} \\
\hline 7 & & & & & \\
\hline & Masculine & مذكر & mudakkar & " & \\
\hline & Feminine & 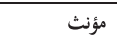 & mu'annat & أمرأة 'imra'a $a^{h}$ Woman & f \\
\hline & Common gender & مذكر أو مؤنث & $\begin{array}{l}\text { mudakkar 'aw } \\
\text { mu'annat }\end{array}$ & ملح milh 'Salt' rوūh 'Soul' & $\mathbf{x}$ \\
\hline
\end{tabular}

Table A.9. Morphological feature of Number attributes and their tags at position 8 .

\begin{tabular}{|c|c|c|c|c|c|}
\hline \multirow{2}{*}{$\begin{array}{l}\text { Position } \\
8\end{array}$} & \multicolumn{4}{|c|}{ Feature Name } & \multirow{3}{*}{$\begin{array}{r}\text { Tag } \\
\mathrm{s}\end{array}$} \\
\hline & \multicolumn{4}{|c|}{ Number العدد al-'adad } & \\
\hline & Singular & مفرد & mufrad & $\begin{array}{l}\text { قalam 'A pen' فلاّ fallāh 'Farmer' منارة manāra }{ }^{h} \\
\text { 'A minaret' }\end{array}$ & \\
\hline & Dual & 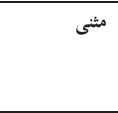 & mutannā & 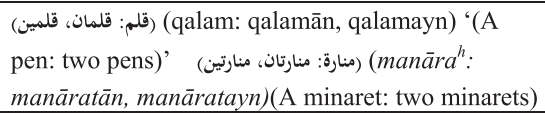 & d \\
\hline & Sound plural & 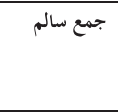 & ğami`sālim & 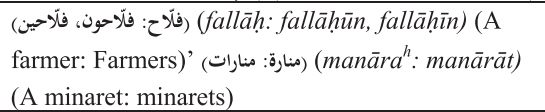 & $\mathbf{p}$ \\
\hline & $\begin{array}{l}\text { Broken } \\
\text { plural }\end{array}$ & 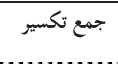 & $\begin{array}{l}\text { ğami } \\
\text { taksìr }\end{array}$ & (قلم: أقلام) (qalam: 'aqlām) '(A pen: pens)' & b \\
\hline & $\begin{array}{l}\text { Plural of } \\
\text { paucity }\end{array}$ & جمع قلة & gami qilla & (حرف: أحرف) (harf: 'ahruf) (A letter: letters) & m \\
\hline & $\begin{array}{l}\text { Plural of } \\
\text { multitude }\end{array}$ & 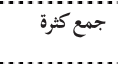 & $\begin{array}{l}\text { gami } \\
\text { katra }^{h}\end{array}$ & (حرف: حروف) (harf: hurūf) (A letter: letters) & $\mathbf{j}$ \\
\hline & $\begin{array}{l}\text { Ultimate } \\
\text { plural }\end{array}$ & 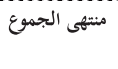 & $\begin{array}{l}\text { munthä al- } \\
\text { ğumür }\end{array}$ & $\begin{array}{l}\text { (مسجد: مساجد) (masğid: masāğgid) (A mosque: } \\
\text { mosques) }\end{array}$ & $\mathbf{u}$ \\
\hline & $\begin{array}{l}\text { Plural of } \\
\text { plural }\end{array}$ & 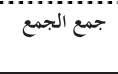 & $\begin{array}{l}\text { ğami al- } \\
\text { gami }\end{array}$ & $\begin{array}{l}\text { (بيت: بُيوت، بُيوتات) (bayt: buyūt, buyūtāt) '(A home: } \\
\text { homes) }\end{array}$ & l \\
\hline & Undefined & غير مُعَرَّف & $\begin{array}{l}\bar{g} a y r \\
m u ' a r r a f\end{array}$ & 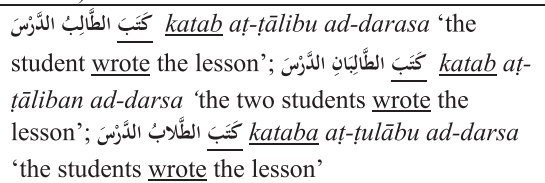 & $\mathbf{x}$ \\
\hline
\end{tabular}

Table A.10. Morphological feature of Person category attributes and their tags at position 9.

\begin{tabular}{|c|c|c|c|c|c|}
\hline Position & \multicolumn{4}{|l|}{ Feature Name } & \multirow[t]{2}{*}{ Tag } \\
\hline 9 & \multicolumn{4}{|c|}{ Person al-'isnād الاسناد } & \\
\hline & First Person & المُكَكَلّْم & al-mutakallim & ' kَبَتُ & $\bar{f}$ \\
\hline & Second Person & المُخاطَب & al-muhātab & كَتَبْتُما katabtumā 'You wrote' & $\mathbf{s}$ \\
\hline & Third Person & الغَائبِ & $a l-\bar{g} \bar{a} ' i b$ & كَبَبَ katabna'They Wrote' & t \\
\hline
\end{tabular}


Table A.11. The morphological feature category of Inflectional Morphology attributes and their tags at position 10 .

\begin{tabular}{|c|c|c|c|c|c|}
\hline Position & \multicolumn{4}{|l|}{ Feature Name } & \multirow[t]{2}{*}{ Tag } \\
\hline 10 & \multicolumn{4}{|c|}{ Inflectional Morphology الصَّف aș-ṣarf } & \\
\hline & $\begin{array}{l}\text { Declined (noun) } \\
\text { Conjugated (verb) }\end{array}$ & مُعرب & mu'rab & ليَيبُ yaḡ̄ōbu 'Miss' & d \\
\hline & $\begin{array}{lll}\begin{array}{l}\text { Triptote } \\
\text { declined }\end{array} & / & \text { fully } \\
\end{array}$ & مُعرب - منصرف & mu'rab - munșarif & غائب $\bar{g} \bar{a}$ 'ib 'Absent' & $\mathbf{v}$ \\
\hline & Non-declinable & الصرف مُعرب - ممنوع من & $\begin{array}{l}\text { mu 'rab - mamnū' } \\
\text { mina aș-șarf }\end{array}$ & 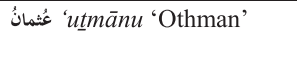 & $\mathbf{p}$ \\
\hline & Invariable $(\mathrm{v}, \mathrm{n})$ & 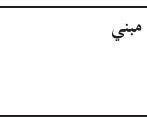 & $m a b n \bar{\imath}$ & 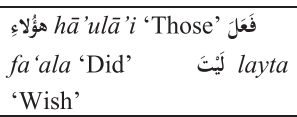 & $\mathbf{s}$ \\
\hline
\end{tabular}

Table A.12. The morphological feature of Case or Mood category attributes and their tags at position 11.

\begin{tabular}{|c|c|c|c|c|c|c|c|}
\hline \multirow{2}{*}{$\begin{array}{l}\text { Position } \\
11\end{array}$} & \multicolumn{6}{|c|}{ Feature Name } & \multirow[t]{2}{*}{ Tag } \\
\hline & \multicolumn{6}{|c|}{ 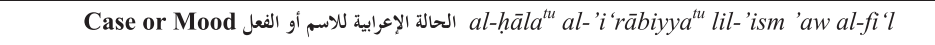 } & \\
\hline & Nominative & Indicative & 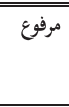 & $\overline{m a r f \bar{u}}$ & $\begin{array}{l}{ }^{2} \text { yaktubu 'He } \\
\text { is writing' }\end{array}$ & $\begin{array}{l}\text { الكتابُ al- } \\
\text { kitābu 'The } \\
\text { Book' }\end{array}$ & $\overline{\mathrm{n}}$ \\
\hline & Accusative & Subjunctive & منصوب & manșūb & 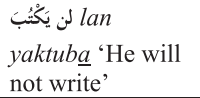 & $\begin{array}{l}\text { الكتاب } \quad a l- \\
\text { kitābba 'The } \\
\text { Book' }\end{array}$ & $\mathbf{a}$ \\
\hline & Genitive & -------- & مجرور & mağrūr & ------ & $\begin{array}{l}\text { الكتاب } \quad \text { al- } \\
\text { kitābi 'The } \\
\text { Book’ }\end{array}$ & g \\
\hline & ------- & $\begin{array}{l}\text { Imperative } \\
\text { or jussive }\end{array}$ & مجزوم & mağzūm & $\begin{array}{l}\text { 'He did not write' } \\
\text { 'He لَكتُبْ lam yaktub }\end{array}$ & ----- & $\mathbf{j}$ \\
\hline
\end{tabular}

Table A.13. The morphological feature category of Case and Mood Marks attributes and tags at position 12 .

\begin{tabular}{|c|c|c|c|c|c|}
\hline \multirow{2}{*}{$\begin{array}{l}\text { Position } \\
12\end{array}$} & \multicolumn{4}{|c|}{ Feature Name } & \multirow[t]{2}{*}{ Tag } \\
\hline & \multicolumn{4}{|c|}{ Case and Mood Marks علامة الإعراب أو البناء 'alāmāt al-'i 'rāb wa al-bināa' } & \\
\hline & damma ${ }^{h}$ & الضمة / الضم & $\begin{array}{c}\text { al-damma }{ }^{h} / \\
\text { al-damm }\end{array}$ & 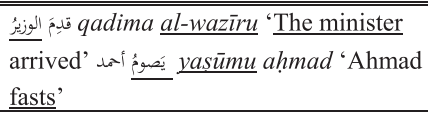 & $\overline{\mathbf{d}}$ \\
\hline & fatha $a^{h}$ & الفتحة / الفتح & $\begin{array}{c}\text { al-fatha }^{h} / \\
\text { al-fath }\end{array}$ & 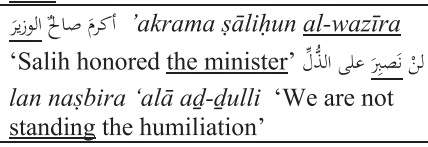 & f \\
\hline & kasra $^{h}$ & الكسرة & $\begin{array}{c}\text { al-kasra }{ }^{h} / \\
\text { al-kasr }\end{array}$ & $\begin{array}{l}\text { خلق الش halaqa allahu as- } \\
\text { samāwāti wa al-'arda 'God created the } \\
\text { skys and the earth' }\end{array}$ & $\mathbf{k}$ \\
\hline
\end{tabular}




\begin{tabular}{|c|c|c|c|c|c|}
\hline \multirow{2}{*}{$\begin{array}{l}\text { Position } \\
12\end{array}$} & \multicolumn{4}{|l|}{ Feature Name } & \multirow[t]{2}{*}{ Tag } \\
\hline & \multicolumn{4}{|c|}{ Case and Mood Marks علامة الإعراب أو البناء 'alāmāt al-'i 'rāb wa al-binā' } & \\
\hline & sukün (Silence) & السكون & as-sukūn & 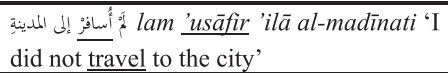 & 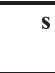 \\
\hline & $w \bar{a} w$ & الواو & $a l-w \bar{a} w$ & 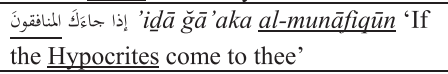 & $\mathbf{w}$ \\
\hline & 'alif & الألف & al-'alif & $\begin{array}{l}\text { التقى الفريقانِ 'iltaqā al-farìqān 'The two } \\
\text { teams have met' }\end{array}$ & a \\
\hline & $y \bar{a}{ }^{\prime}$ & الياء & $a l-y \bar{a}$ & 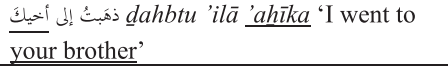 & $\mathbf{y}$ \\
\hline & Inflectional $n \bar{u} n$ & ثبوت النون & $\underline{t} u b \bar{u} t$ an-nūn & 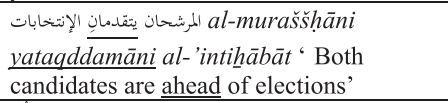 & $\mathbf{n}$ \\
\hline & Deletion of $n \bar{u} n$ & حذف النون & hadf $a n-n \bar{u} n$ & 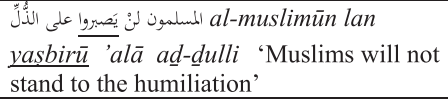 & $\mathbf{0}$ \\
\hline & $\begin{array}{l}\text { Deletion of vowel } \\
\text { letter }\end{array}$ & حذف حرف العلَّة & $\begin{array}{l}\text { hadf harf al- } \\
\text { 'illa }\end{array}$ & 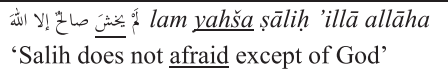 & $\mathbf{v}$ \\
\hline
\end{tabular}

Table A.14. The morphological feature of Definiteness category attributes and their tags at position 13 .

\begin{tabular}{|c|c|c|c|c|c|}
\hline \multirow{2}{*}{$\begin{array}{l}\text { Position } \\
13\end{array}$} & \multicolumn{4}{|l|}{ Feature Name } & \multirow[t]{2}{*}{ Tag } \\
\hline & \multicolumn{4}{|c|}{ Definiteness المَعُفِةَة والنَكِكِة al-ma 'rifa ${ }^{t i}$ wa an-nakira ${ }^{t i}$} & \\
\hline & Definiteness & مَعْفِة & ma'rifa ${ }^{h}$ & al-kitāab 'The book' & d \\
\hline & Indefiniteness & نَكِرَة & nakira $^{h}$ & كتاب kitāb 'A book' & $\mathbf{i}$ \\
\hline
\end{tabular}

Table A.15. The morphological feature of Voice category attributes and their tags at position 14 .

\begin{tabular}{|c|c|c|c|c|c|}
\hline \multirow{2}{*}{$\begin{array}{l}\text { Position } \\
14\end{array}$} & \multicolumn{4}{|l|}{ Feature Name } & \multirow[t]{2}{*}{ Tag } \\
\hline & \multicolumn{4}{|c|}{ 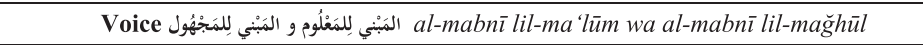 } & \\
\hline & Active voice & مَبْني للمَعْلُوم & mabnì lil-ma'lüm & Kataba 'He wrote' & (a \\
\hline & Passive voice & مَبْنِ للمَجْهُول & mabnī lil-mă̆hūl & kutiba 'It was written' & $\mathbf{p}$ \\
\hline
\end{tabular}

Table A.16. The morphological feature of Emphasized and Non-emphasized category attributes and their tags at position 15 .

\begin{tabular}{|c|c|c|c|c|c|}
\hline Position & Feature Name & & & & \multirow[t]{2}{*}{ Tag } \\
\hline 15 & \multicolumn{4}{|c|}{ Emphasized and Non-emphasized المُؤكَد وغيرُ المُؤَكَد al-mu'akkad wa gayir al-mu'akkad } & \\
\hline & Emphatic verb & فعل مُؤكَّد & fi'l mu'akkad & $\begin{array}{l}\text { write' la'aktubanna 'I will } \\
\text { wثَّنَ' }\end{array}$ & $\overline{\mathrm{n}}$ \\
\hline & Non-emphatic verb & فعل غَيْر مُؤكَّد & fi'l gayr mu'akkad & أكُتَبُ 'aktubu 'I am writing' & $\mathbf{m}$ \\
\hline
\end{tabular}


Table A.17. The morphological feature of Transitivity category attributes and their tags at position 16.

\begin{tabular}{|c|c|c|c|c|c|}
\hline \multirow{2}{*}{$\begin{array}{l}\text { Position } \\
16 \\
\end{array}$} & \multicolumn{4}{|c|}{ Feature Name } & \multirow[t]{2}{*}{ Tag } \\
\hline & \multicolumn{4}{|c|}{ Transitivity اللازم والمتعدي al-lāzim wa al-muta 'adi } & \\
\hline & Intransitive & لالازٍ & lāzim & $\begin{array}{l}\text { نامَ الولد na al-waladu'The boy } \\
\text { slept' }\end{array}$ & i \\
\hline & $\begin{array}{l}\text { Singly } \\
\text { transitive }\end{array}$ & مُتَعلدُ إلى مَفْعُول واحِد & 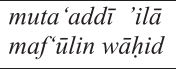 & 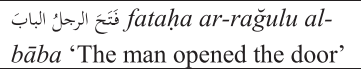 & $\mathbf{0}$ \\
\hline & $\begin{array}{l}\text { Doubly } \\
\text { transitive }\end{array}$ & مُمَعلدُ إلىى مَفْعُولَئن & $\begin{array}{l}\text { muta'add̄̄ 'ilā } \\
\text { maf'ülayn }\end{array}$ & $\begin{array}{l}\text { أعظاه د'a 'atāhu dīnāar } r^{a n} \text { 'He gave } \\
\text { him a dinar' }\end{array}$ & $\mathbf{b}$ \\
\hline & $\begin{array}{l}\text { Triply } \\
\text { transitive }\end{array}$ & مُتَعلدُ إلىى ثَلَالَة مَفاعِيل & 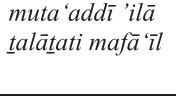 & 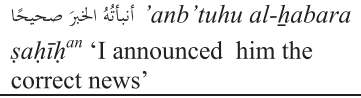 & $\mathbf{t}$ \\
\hline
\end{tabular}

Table A.18. Morphological feature category of Rational attributes and their tags at position 17.

\begin{tabular}{|c|c|c|c|c|c|}
\hline Position & \multicolumn{4}{|c|}{ Feature Name } & \multirow[t]{2}{*}{ Tag } \\
\hline 17 & \multicolumn{4}{|c|}{ Rational العاقل وغير العاقل al- 'āqil wa ḡayir al- 'āqil } & \\
\hline & Rational & عاقِل & 'āqil & 整 qara'a 'Read' & h \\
\hline & Irrational & غَيْر غَاقِل & $\bar{g} a y r$ 'àqil & nabaha 'Bark' & n \\
\hline
\end{tabular}

Table A.19. The morphological feature of Declension and Conjugation category attributes and their tags at position 18 .

\begin{tabular}{|c|c|c|c|c|c|}
\hline \multirow{2}{*}{$\begin{array}{l}\text { Position } \\
18 \\
\end{array}$} & \multicolumn{4}{|l|}{ Feature Name } & \multirow[t]{2}{*}{ Tag } \\
\hline & \multicolumn{4}{|c|}{ Declention and Conjugation التُصريف at-tașrīff } & \\
\hline & Non-Inflected (n, v) & غير مُتصَرِف & gayr mutașarrif & ئو huwa 'Him' & $\mathbf{n}$ \\
\hline & $\begin{array}{l}\text { Primitive / Concrete } \\
\text { noun }\end{array}$ & 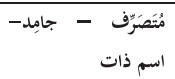 & $\begin{array}{l}\text { mutașarrif- } \bar{g} \bar{a} m i d \\
\text { - 'ism } \underline{\text { datat }}\end{array}$ & شَجُة šağara ${ }^{h}$ 'A tree' & t \\
\hline & $\begin{array}{l}\text { Primitive / Abstract } \\
\text { noun }\end{array}$ & 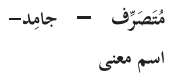 & $\begin{array}{l}\text { mutașarrif- ğāmid } \\
\text { - 'ism ma'nō }\end{array}$ & 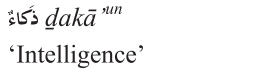 & $\mathbf{a}$ \\
\hline & $\begin{array}{l}\text { Inflected / Derived } \\
\text { noun }\end{array}$ & مُتَتصرِّف - اسم مُشْتَقُ & $\begin{array}{l}\text { mutașarrif-'ism } \\
\text { muštaqq }\end{array}$ & $\begin{array}{l}\text { مكتبة 'Aitāb }{ }^{\text {un }} \text { 'A book' } \\
\text { maktaba } a^{\text {tun }} \text { 'A library' }\end{array}$ & d \\
\hline & $\begin{array}{l}\text { Non-conjugated } \\
\text { restricted to the perfect }\end{array}$ & 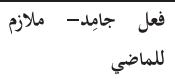 & $\begin{array}{l}\text { fìl ğgāmid-mulāzim } \\
\text { lil-maḍ̂̄ }\end{array}$ & نَ na ima 'Be happy' & $\mathbf{p}$ \\
\hline & $\begin{array}{l}\text { Non-conjugated } \\
\text { restricted to the } \\
\text { imperfect }\end{array}$ & 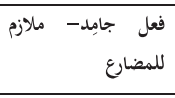 & $\begin{array}{l}\text { fi'l ğāamid-mulāzim } \\
\text { lil-mudạari' }\end{array}$ & يَيْيطُ yahịtu 'Scream' & c \\
\hline & $\begin{array}{l}\text { Non-conjugated } \\
\text { restricted to the } \\
\text { imperative }\end{array}$ & فلأمر & $\begin{array}{l}\text { fi'l ğgāmid-mulāzim } \\
\text { lil-'amr }\end{array}$ & هَبْ hab 'Suppose' & $\mathbf{i}$ \\
\hline & $\begin{array}{l}\text { Conjugated / fully } \\
\text { conjugated verb }\end{array}$ & 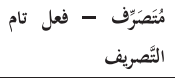 & $\begin{array}{l}\text { mutașarrif }-f i \mathfrak{l} \text { t } \\
\text { tām at-tașarị̂f }\end{array}$ & $\begin{array}{l}\text { يكتبُ yaktubu 'He is' } \\
\text { writing' }\end{array}$ & $\mathbf{v}$ \\
\hline & $\begin{array}{l}\text { Conjugated / partially } \\
\text { conjugated verb }\end{array}$ & المُتَصرَّرف - فعل ناقص & $\begin{array}{l}\text { mutașarrif-fi'l } \\
\text { nāqis at-tașarîf }\end{array}$ & $\begin{array}{l}\text { كاد kāda 'Close; near or } \\
\text { almost' }\end{array}$ & m \\
\hline
\end{tabular}


Table A.20. The morphological feature of Unaugmented and Augmented category attributes and their tags at position 19.

\begin{tabular}{|c|c|c|c|c|c|}
\hline \multirow{2}{*}{$\begin{array}{l}\text { Position } \\
19\end{array}$} & \multicolumn{4}{|l|}{ Feature Name } & \multirow[t]{2}{*}{ Tag } \\
\hline & \multicolumn{4}{|c|}{ Unaugmented and Augmented المُجُرَّد والمَزِيد al-muğarrad wa al-mazìd } & \\
\hline & Unaugmented & مُجرَّرد & al-muğarrad & kataba 'Wrote' & $\mathbf{s}$ \\
\hline & Augmented by one letter & مَزيْدَ بِحَرف & mazīd bi harf & kَ̄taba 'Wrote' & a \\
\hline & Augmented by two letters & مَزيْدِد بِحَرفَيْن & $\begin{array}{l}\text { mazìd bi } \\
\text { harfayn }\end{array}$ & $\begin{array}{l}\text { 'iktataba } \\
\text { 'Subscribed' }\end{array}$ & b \\
\hline & Augmented by three letters & مَزْيْد بِيَلاثَة أحرف & $\begin{array}{l}\text { mazìd bi talātat } \\
\text { 'ahruf }\end{array}$ & 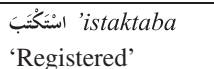 & $\mathbf{t}$ \\
\hline & Augmented by four letters & مَزْيدّ بأربعة أحرف & $\begin{array}{l}\text { mazìd bi } \\
\text { 'arba'ati 'ahruf }\end{array}$ & $\begin{array}{l}\text { استقبال 'istiqbāl } \\
\text { 'Reception' }\end{array}$ & $\mathbf{q}$ \\
\hline
\end{tabular}

Table A.21. The morphological feature of Number of Root Letters category attributes and their tags at position 20.

\begin{tabular}{|c|c|c|c|c|c|}
\hline \multirow{2}{*}{$\begin{array}{l}\text { Position } \\
20\end{array}$} & \multicolumn{4}{|l|}{ Feature Name } & \multirow[t]{2}{*}{ Tag } \\
\hline & \multicolumn{4}{|c|}{ Number of Root Letters عَدَد أحخرَف الجَذْر adad 'ahruf al-ğgadr } & \\
\hline & Triliteral & ثُلاثي & $\underline{t} u l \bar{a} \underline{t} \bar{\imath}$ & ل & $\mathbf{t}$ \\
\hline & Quadriliteral & رُباعبي & $r u b \bar{a} \mathfrak{l}^{\prime}$ & 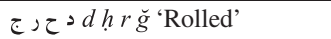 & $\mathbf{q}$ \\
\hline & Quinqueliteral & خُمابِي & $\underline{h} u m \bar{a} s \bar{l}$ & 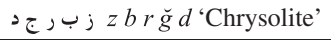 & f \\
\hline
\end{tabular}

Table A.22. The morphological feature of Verb Root category attributes and their tags at position 21 .

\begin{tabular}{|c|c|c|c|c|}
\hline \multirow{2}{*}{$\begin{array}{l}\text { Position } \\
21\end{array}$} & \multicolumn{3}{|l|}{ Feature Name } & \multirow{3}{*}{$\begin{array}{r}\text { Tag } \\
\mathbf{a}\end{array}$} \\
\hline & \multicolumn{3}{|c|}{ Verb Root بُنية الفعل bunya ${ }^{t u}$ al-fi'l } & \\
\hline & Intact verb & صحيح & sahịh & \\
\hline & Doubled verb & مضعف & muḍa"af & b \\
\hline & Initially-hamzated verb & مهموز الفاء & $m a h m \bar{u} z$ al-fắ & c \\
\hline & $\begin{array}{l}\text { Initially-hamzated and } \\
\text { doubled verb }\end{array}$ & مهموز الفاء مضعَف & mahmūz al-fā' muda' 'af & d \\
\hline & $\begin{array}{l}\text { Initially and finally hamzated } \\
\text { verb }\end{array}$ & مهموز الفاء ومهموز اللام & mahmūz al-fāa' wa mahmūz al-lām & $\mathbf{e}$ \\
\hline & Medially-hamzated verb & مهموز العين & mahmūz al-'ayn & f \\
\hline & Finally-hamzated verb & مهموز اللام & mahmūz al-lām & g \\
\hline & $w \bar{a} w$-initial verb & مثال واوي & mițāl wāwì & h \\
\hline & $w \bar{a} w$-initial and doubled verb & مثال واوي مضعف & mitâal wāwī muda" "af & i \\
\hline & $\begin{array}{l}\text { wāw- initial and medially- } \\
\text { hamzated verb }\end{array}$ & مثال واوي مهموز العين & mițāl wāwì mahmūz al-'ayn & $\mathbf{j}$ \\
\hline & $\begin{array}{l}w \bar{a} w \text {-initial and finally- } \\
\text { hamzated verb }\end{array}$ & مثال واوي مهموز اللام & mițāl wāwì mahmūz al-lām & $\mathbf{k}$ \\
\hline & $y \bar{a}$-initial verb & مثال يائي & mițāl yā' & 1 \\
\hline & $y \bar{a}^{\prime}$-initial and doubled verb & مثال يائي مضعف & mițāl yā' & $\mathbf{m}$ \\
\hline & $\begin{array}{l}y \bar{a}^{\prime}-\text { initial and medially- } \\
\text { hamzated verb }\end{array}$ & مثال يائي مهموز العين & mițāl yā' ’̀ mahmūz al-'ayn & $\mathbf{n}$ \\
\hline & Hollow with wāw & أجوف واوي & 'ağwaf wāwi & $\mathbf{0}$ \\
\hline & $\begin{array}{l}\text { Hollow with } w \bar{a} w \text { and } \\
\text { initially-hamzated verb }\end{array}$ & أجوف واوي مهموز الفاء & 'ağwaf wāwī mahmūz al-fä' & $\mathbf{p}$ \\
\hline
\end{tabular}




\begin{tabular}{|c|c|c|c|c|}
\hline \multirow{2}{*}{$\begin{array}{l}\text { Position } \\
21 \\
\end{array}$} & \multicolumn{3}{|l|}{ Feature Name } & \multirow{3}{*}{$\begin{array}{r}\text { Tag } \\
\mathbf{q}\end{array}$} \\
\hline & \multicolumn{3}{|c|}{ Verb Root بنية الفعل bunya ${ }^{t u}$ al-fi'l } & \\
\hline & $\begin{array}{l}\text { Hollow with } w \bar{a} w \text { and finally- } \\
\text { hamzated verb }\end{array}$ & أجوف واوي مهموز اللام & 'ağwaf wāwī mahmūz al-lām & \\
\hline & Hollow with $y \bar{a}^{\prime}$ & أجوف يائي & 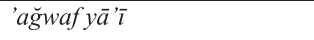 & $\mathbf{r}$ \\
\hline & $\begin{array}{l}\text { Hollow with } y \bar{a}^{\prime} \text { and initially- } \\
\text { hamzated verb }\end{array}$ & أجوف يائي مهموز الفاء & 'ağwaf yā' '̄ mahmīz al-fā' & $\mathbf{s}$ \\
\hline & $\begin{array}{l}\text { Hollow with } y \bar{a}^{\prime} \text { and finally- } \\
\text { hamzated verb }\end{array}$ & أجوف يائي مهموز اللام & 'ă̆waf yā' '̄ mahmūz al-lām & $\mathbf{t}$ \\
\hline & Defective with $w \bar{a} w$ verb & ناقص واوي & $n \bar{a} q i s ̣$ wāwi & $\mathbf{u}$ \\
\hline & $\begin{array}{l}\text { Defective with } w \bar{a} w \text { and } \\
\text { initially-hamzated verb }\end{array}$ & ناقص واوي مهموز الفاء & $n \bar{a} q i s ̣$ wāwì mahmūz al-fáa' & $\mathbf{v}$ \\
\hline & $\begin{array}{l}\text { Defective with } w \bar{a} w \text { and } \\
\text { medially-hamzated verb }\end{array}$ & نافص واوي مهموز العين & nāqiṣ wāwī mahmūz al-'ayn & $\mathbf{w}$ \\
\hline & Defective with $y \bar{a}^{\prime}$ verb & ناقص يائي & nāqis y $\bar{a}^{\prime} \bar{\imath}$ & $\mathbf{x}$ \\
\hline & $\begin{array}{l}\text { Defective with } y \bar{a}^{\prime} \text { and } \\
\text { initially-hamzated verb }\end{array}$ & ناقص يائي مهموز الفاء & nāqiș yā' $\bar{\imath}$ mahmūz al-fā' & $\mathbf{y}$ \\
\hline & $\begin{array}{l}\text { Defective with } y \bar{a}^{\prime} \text { and } \\
\text { medially-hamzated verb }\end{array}$ & ناقص يائي مهموز العين & nāqiș yā' $\bar{l}$ mahmūz al- 'ayn & $\mathbf{Z}$ \\
\hline & Adjacent doubly-weak verb & لفيف مقرون & lafï maqrūn & * \\
\hline & $\begin{array}{l}\text { Adjacent doubly-weak and } \\
\text { initially-hamzated verb }\end{array}$ & لفيف مقرون مهموز الفاء & lafï maqrūn mahmūz al-fă' & $\$$ \\
\hline & Separated doubly-weak verb & لفيف مفروق & lafï mafrū $q$ & 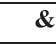 \\
\hline & $\begin{array}{l}\text { Separated doubly-weak and } \\
\text { medially-hamzated verb }\end{array}$ & لفيف مفروق مهموز العين & lafï mafrūq mahmūz al-'ayn & (a) \\
\hline
\end{tabular}

Table A.23. The morphological feature of Noun Finals category attributes and their tags at position 22.

\begin{tabular}{|c|c|c|c|c|c|}
\hline \multirow{2}{*}{$\begin{array}{l}\text { Position } \\
22\end{array}$} & \multicolumn{4}{|l|}{ Feature Name } & \multirow[t]{2}{*}{ Tag } \\
\hline & \multicolumn{4}{|c|}{ Noun Finals أقسام الأسم تبعاً للفظ آخره 'aqsām al-'ismi tib 'an li-lafẓi 'āhirhi } & \\
\hline & Sound noun & الاسم صحيح الآخر & $\begin{array}{l}\text { al-'ism șaḥ̄h } \\
\text { al-'āir }\end{array}$ & $\begin{array}{l}\text { جبل gabal 'Mountain' نهر nahr } \\
\text { 'River' درهم dirham 'Dirham } \\
\text { (currency)' }\end{array}$ & $\mathbf{S} \mathbf{S}$ \\
\hline & Semi-sound noun & الاسم شبه الصحيح & $\begin{array}{l}\text { al-'ism šibh } \\
\text { aș-șahn̄ḥ }\end{array}$ & هُلْو dalw 'Bucket' بهو bahw 'Hall' & i \\
\hline & $\begin{array}{l}\text { Noun with } \\
\text { shortened ending }\end{array}$ & الاسم المقصور & $\begin{array}{l}\text { al-'ism al- } \\
\text { maqșūr }\end{array}$ & بُ بُشْرَى bušra 'Glad tidings' & $\mathbf{t}$ \\
\hline & $\begin{array}{l}\text { Noun with } \\
\text { extended ending }\end{array}$ & 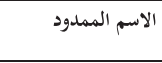 & $\begin{array}{l}\text { al-'ism al- } \\
\text { mamdūd }\end{array}$ & سَمَاء samā' 'Sky' & e \\
\hline & $\begin{array}{l}\text { Noun with curtailed } \\
\text { ending }\end{array}$ & 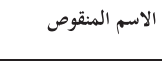 & $\begin{array}{l}\text { al-'ism al- } \\
\text { manqūṣ }\end{array}$ & al-qā $d \bar{l} \bar{l}$ 'The' judge’ & c \\
\hline & $\begin{array}{l}\text { Noun with deleted } \\
\text { ending }\end{array}$ & الاسم محذوف الآخر & $\begin{array}{l}\text { al-'ism maḥdūf } \\
\text { al-'āhir }\end{array}$ & 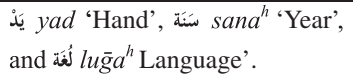 & d \\
\hline
\end{tabular}

\section{Notes}

1. We would like to thank all the participants of the workshop of morphological analyzer experts for Arabic language, organized by the Arab League Educational, Cultural and Scientific Organization (ALECSO), King Abdul Aziz City for Science and Technology (KACST) and the Arabic Language Academy, Damascus, Syria, 26-28 April 2009, for their suggestions and agreement on the classification of morphological features of Arabic words. We want to thank Mr. Marwan Al-Bawab (Member of the Arabic 
Language Academy in Damascus, Syria), for his valuable advice and comments on designing the SALMA - Tag Set of Arabic to ensure that it adheres to traditional Arabic grammar.

We would like to thank Professor James Dickins, Head of Arabic and Middle Eastern Studies, University of Leeds, Leeds, UK, for standardizing the English translations of Arabic grammar terms in this paper, and for his efforts in reviewing the paper.

2. http://acopost.sourceforge.net/

3. http://12r.cs.uiuc.edu/ $\sim \operatorname{cog} c o m p /$ asoftware.php?skey $=$ POS

4. http://12r.cs.uiuc.edu/ $\sim \operatorname{cog} \operatorname{comp} /$ asoftware.php? skey=FLBJPOS

5. http://www.nltk.org/

6. http://opencog.org/wiki/RelEx

7. http://nlp.ipipan.waw.pl/Spejd/

8. http://beta.visl.sdu.dk/cg3.html

9. Automatic Mapping Among Lexico-Grammatical Annotation Models (AMALGAM) http://www.comp.leeds.ac.uk/amalgam/amalgam/amalghome.htm

10. http://www.comp.leeds.ac.uk/eric/latifa/arabic_corpora.htm

11. LDC Arabic POS tagging documentation http://www.ircs.upenn.edu/arabic/ Jan03release/POS-info.txt

12. MorphoChallenge 2009 Qur'an Gold Standard http://www.cis.hut.fi/morphochallenge2009/ datasets.shtml

13. EAGLES Recommendations for the Morphosyntactic Annotation of Corpora. EAGLES document EAG-TCWG-MAC/R. http://www.ilc.cnr.it/EAGLES96/pub/ eagles/corpora/annotate.ps.gz

14. http://www.ircs.upenn.edu/arabic/pos.html

15. The Annotation Manual of the SALMA Tag Set for Arabic http://www.comp. leeds.ac.uk/sawalha/tagset.html

16. According to Wright's (1986) classifications. Ryding (2005) classifies nouns according to gender into two classes: masculine and feminine, and the 'dual gender noun' is mentioned in a footnote on page 119 .

17. Recently the word نائب $n \bar{a}$ ' $i b$ is being used for both masculine and feminine as the regular feminine form of this word نائبة $n \bar{a}$ 'iba $a^{h}$ means 'disaster' which is not suitable to indicate feminine parliament member.

\section{References}

Al-Ghalayyni 2005. جامع الدروس العربية "Fami” Al-Duroos Al-Arabia”. Saida - Lebanon: AlMaktaba Al-Asriyiah “المكتبة العصرية".

Al-Shamsi, Fatima and Guessoum, Ahmad 2006. A Hidden Markov Model-Based POS Tagger for Arabic. 8es Fournées internationales d'Analyse statistique des Données Textuelles.

Al-Sulaiti, Latifa and Atwell, Eric 2004. Designing and developing a corpus of contemporary Arabic TALC 2004: Proceedings of the sixth Teaching And Language Corpora conference 92-93.

Al-Sulaiti, Latifa and Atwell, Eric 2005. Extending the Corpus of Contemporary Arabic. Corpus Linguistics conference 2005 University of Birmingham, UK.

Al-Sulaiti, Latifa and Atwell, Eric 2006. The design of a corpus of contemporary Arabic? International Fournal of Corpus Linguistics 11: 135-171. 
ALECSO 2008. Sarf - Arabic Morphology System. The Arab League Educational, Cultural and Scientific Organization (ALECSO).

Alqrainy, Shihadeh 2008. A Morphological-Syntactical Analysis Approach For Arabic Textual Tagging. Leicester, UK: De Montfort University.

Altabbaa, Mohammad, Al-Zaraee, Ammar and Shukairy, Mohammad Arif 2010. An Arabic Morphological Analyzer and Part-Of-Speech Tagger Qutuf 'قُطوف'. Damascus: Arab International University.

Atwell, Eric 2008. Development of tag sets for part-of-speech tagging. In Anke Ludeling and Merja Kytö (eds.), Corpus linguistics: an international handbook, volume 1, Mouton de Gruyter. 501-526.

Atwell, Eric, Demetriou, George, Hughes, John, Schiffrin, Amanda, Souter, Clive and Wilcock, Sean 2000. A comparative evaluation of modern English corpus grammatical annotation schemes. ICAME Journal, International Computer Archive of Modern and medieval English, Bergen 24: 7-23.

Bamman, David and Crane, Gregory 2008. Building a Dynamic Lexicon from a Digital Library. Proceedings of the 8th ACM/IEEE-CS Joint Conference on Digital Libraries (7CDL 2008) Pittsburgh.

Brill, Eric 1995. Transformation-Based Error-Driven Learning and Natural Language Processing: A Case Study in Part-of-Speech Tagging. Computational Linouistics 21: 543 565.

Cachia, Pierre 1973. The monitor: a dictionary of Arabic grammatical terms : Arabic-English, English-Arabic / compiled by Pierre Cachia. Beirut: Librairie du Liban.

Dahdah, Antonie 1987. A dictionary of Arabic Grammer in Charts and Tables "معجم قو اعد اللغة العربيه في جداول ولوحات، Beirut, Lebanon: Librairie du Liban publisher.

Dahdah, Antonie 1993. A dictionary of Arabic Grammatical nomenclature Arabic-English "معجم لغة النحو العربي عربي-انكليزي". Beirut, Lebanon: Librairie du Liban publishers.

Diab, Mona, Hacioglu, Kadri and Jurafsky, Daniel 2004. Automatic Tagging of Arabic Text: From raw text to Base Phrase Chunks. Proceedings of HLT-NAACL.

Diab, Mona T. 2007. Towards an Optimal POS Tag Set for Arabic Processing. Proc RANLP.

Dror, Judith, Shaharabani, Dudu, Talmon, Rafi and Wintner, Shuly 2004. Morphological Analysis of the Qur'an. Literary and Linouistic Computing 19: 431-452.

Duh, Kevin and Kirchhoff, Katrin 2005. POS Tagging of Dialectal Arabic: A Minimally Approach. ACL-05, Computational Approaches to Semitic Languages Workshop Proceedings 55-62. University of Michigan Ann Arbor, Michigan, USA.

Dukes, Kais, Atwell, Eric and Habash, Nizar 2011. Supervised Collaboration for Syntactic Annotation of Quranic Arabic. Language Resources and Evaluation Fournal (LREF). Special Issue on Collaboratively Constructed Language Resources.

Dukes, Kais, Atwell, Eric and Sharaf, Abdul-Baquee. M. 2010. Syntactic Annotation Guidelines for the Quranic Arabic Dependency Treebank. Language Resources and Evaluation Conference (LREC 2010) Valletta, Malta.

Dukes, Kais and Habash, Nizar 2010. Morphological Annotation of Quranic Arabic. Proceedings of the Seventh conference on International Language Resources and Evaluation (LREC'10) Valletta, Malta, 19-21 May 2010: European Language Resources Association (ELRA).

Elliott, John and Atwell, Eric 2000. Is anybody out there?: the detection of intelligent and generic language-like features. 7 BIS: Fournal of the British Interplanetary Society 53: 7-23.

Freeman, Andrew 2001. Brill's POS Tagger and a Morphology Parser for Arabic. NAACL 2001 Student Research Workshop, Lancaster University. 
Habash, Nizar, Faraj, Reem and Roth, Ryan 2009. Syntactic Annotation in Columbia Arabic Treebank. 2nd International Conference on Arabic Language Resources E Tools MEDAR 2009 Cairo, Egypt.

Habash, Nizar and Rambow, Owen 2005. Arabic tokenization, part-of-speech tagging and morphological disambiguation in one fell swoop. Proceedings of the 43rd Annual Meeting on Association for Computational Linguistics Ann Arbor, Michigan: Association for Computational Linguistics.

Habash, Nizar and Roth, Ryan M. 2009. CATiB: The Columbia Arabic Treebank. Proceedings of the ACL-IFCNLP 2009 Conference Short Papers 221-224. Suntec, Singapore.

Hamada, Salwa 2010. مقترح لمعايير وضوابط ثقييم المحلّلات الصرفية Svaluation of the Arabic Morphological Analyzers? Proceedings of The Sixth International Computing science Conference ICCA Hammamet, Tunisia.

Harmain, Harmain M. 2004. Arabic Part-of-Speech Tagging. The Fifth Annual U.A.E. University Research Conference United Arab Emirates.

Johansson, Stig, Atwell, Eric, Garside, Roger and Leech, Geoffrey 1986. The Tagged LOB Corpus. Bergen, Norway: Norwegian Computing Centre for the Humanities.

Khoja, Shereen 2001. APT: Arabic Part-of-Speech Tagger. Student Workshop at the Second Meeting of the North American Chapter of the Association for Computational Linguistics (NAACL2001) Carnegie Mellon University, Pittsburgh, Pennsylvania.

Khoja, Shereen 2003. APT: An Automatic Arabic Part-of-Speech Tagger. Lancaster, UK: Lancaster University.

Khoja, Shereen, Garside, Porger and Knowles, Gerry 2001. A tagset for the morphosynactic tagging of Arabic. Corpus Linguistics 2001 Lancaster University, Lancaster, UK.

Leech, Geoffrey and Wilson, Andrew 1999. Standards for Tagsets. In Hans van Halteren (ed.), Syntactic Wordclass Tagging. KLUWER Academic Publishers. 55-80.

Maamouri, Mohamed and Bies, Ann 2004. Developing an Arabic Treebank: Methods, Guidelines, Procedures, and Tools. Proceedings of the 20th International Conference on Computational Linguistics (COLING 2004).

Marsi, Erwin, Bosch, Antal van den and Soudi, Abdelhadi 2005. Memory-based morphological analysis generation and part-of-speech tagging of Arabic. Proceedings of the ACL Workshop on Computational Approaches to Semitic Languages 1-8. Ann Arbor: Association for Computational Linguistics.

Monachini, Monica and Calzolari, Nicoletta 1996. Synopsis and comparison of morphosyntactic phenomena encoded in lexicons and corpora. A common proposal and applications to European languages. Pisa, Italy: Istituto di Linguistica Computazionale -CNR.

Ryding, Karin C. 2005. A Reference Grammar of Modern Standard Arabic. Cambridge University Press.

Sawalha, Majdi 2011. Open-source Resources and Standards for Arabic Word Structure Analysis. School of Computing Leeds: University of Leeds.

Sawalha, Majdi and Atwell, Eric 2009a. Linguistically Informed and Corpus Informed Morphological Analysis of Arabic. Proceedings of the 5th International Corpus Linguistics Conference CL2009 Liverpool, UK.

Sawalha, Majdi and Atwell, Eric 2009b.

توظيف قو اعد النحو و الصرف في بناء محلل صرفي للغة العربية (Adapting Language Grammar Rules for Building Morphological Analyzer for Arabic Language). Proceedings of the morkshop of morphological analyzer experts for Arabic language, organized by Arab League 
Educational, Cultural and Scientific Organization (ALECSO), King Abdul-Aziz City for Science and Technology (KACST) and Arabic Language Academy. Damascus, Syria.

Sawalha, Majdi and Atwell, Eric 2010. Fine-Grain Morphological Analyzer and Part-of-Speech Tagger for Arabic Text. Language Resource and Evaluation Conference LREC 2010 Valleta, Malta: European Language Resources Association (ELRA).

Schmid, Helmut and Laws, Florian 2008. Estimation of Conditional Probabilities with Decision Trees and an Application to Fine-Grained POS Tagging. COLING'08 Manchester,UK.

Talmon, Rafi and Wintner, Shuly 2003. Morphological Tagging of the Qur'an. In Proceedings of the Workshop on Finite-State Methods in Natural Language Processing, an EACL'03 Workshop Budapest, Hungary.

Teahan, Bill 1998. Modeling English Text. Department of Computer Science New Zealand: University of Waikato.

Teufel, Simone, Schmid, Helmut, Heid, Ulrich and Schiller, Anne 1996. Study of the relation between tagsets and taggers. Stuttgart, Germany Institut für maschinelle Sprachverarbeitung, Universität Stuttgart

Tlili-Guiassa, Yamina 2006. Hybrid Method for Tagging Arabic Text. Fournal of Computer Science 2, 245-248.

Voutilainen, Atro 2003. Part-of-Speech Tagging. In Ruslan Mitkov (ed.), The Oxford Handbook of Computational Linguistics 219-232. Oxford University Press.

Wright, W. 1996. A Grammar of the Arabic Language, Translated from the German of Caspari, and Editted with Numerous Additions and Corrections. Beirut: Librairie du Liban.

Zibri, Chiraz Ben Othmane, Torjmen, Aroua and Ahmad, Mohamed Ben 2006. An Efficient Multi-agent system Combining POS-Taggers for Arabic Texts. CICLing 2006, LNCS 3878. Zolfagharifard, Ellie 2009. Anti-terror technology tool uses human logic. The Engineer.

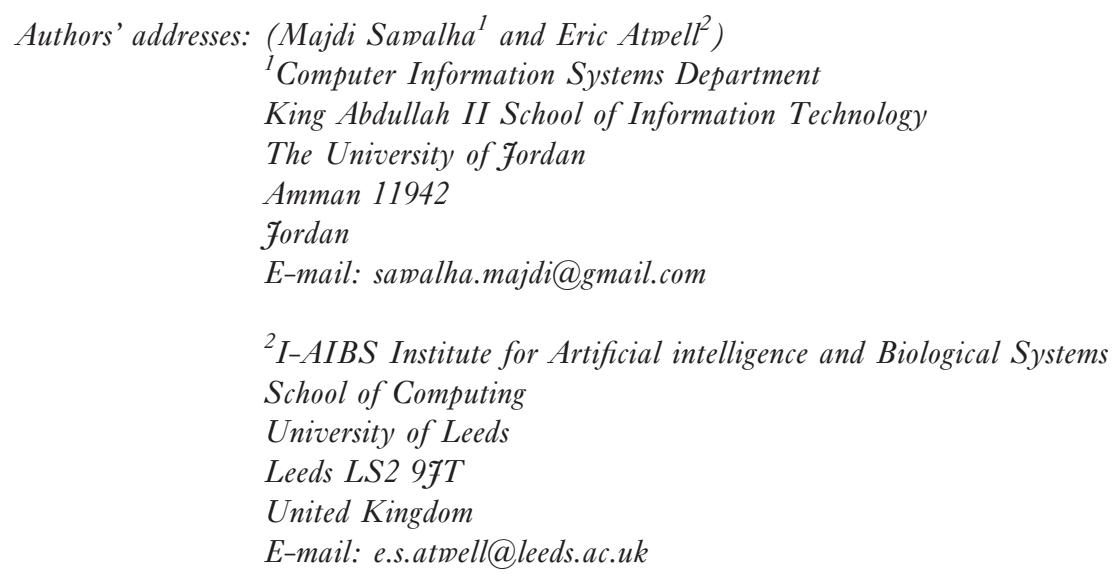

